\title{
Conocimientos, actitudes y prácticas relacionadas a la pandemia del COVID-19 en comunidades indígenas de Yucatán y Chiapas
}

Isabel Vieitez Martínez

Population Council

Silvana Larrea

Population Council

Fabiola Romero

Population Council

Ludivine Cicolella

Population Council

Follow this and additional works at: https://knowledgecommons.popcouncil.org/departments_sbsr-pgy

Part of the Demography, Population, and Ecology Commons, International Public Health Commons, and the Public Health Education and Promotion Commons How does access to this work benefit you? Let us know!

\section{Recommended Citation}

Martínez, Isabel Vieitez, Silvana Larrea, Fabiola Romero, and Ludivine Cicolella. 2020. "Conocimientos, actitudes y prácticas relacionadas a la pandemia del COVID-19 en comunidades indígenas de Yucatán y Chiapas." Mexico: Population Council. 
CONOCIMIENTOS, ACTITUDES Y PRÁCTICAS RELACIONADAS A LA PANDEMIA DEL COVID-19 EN COMUNIDADES INDÍGENAS DE YUCATÁN Y CHIAPAS

Isabel Vieitez

Silvana Larrea

Fabiola Romero

Ludivine Cicolella

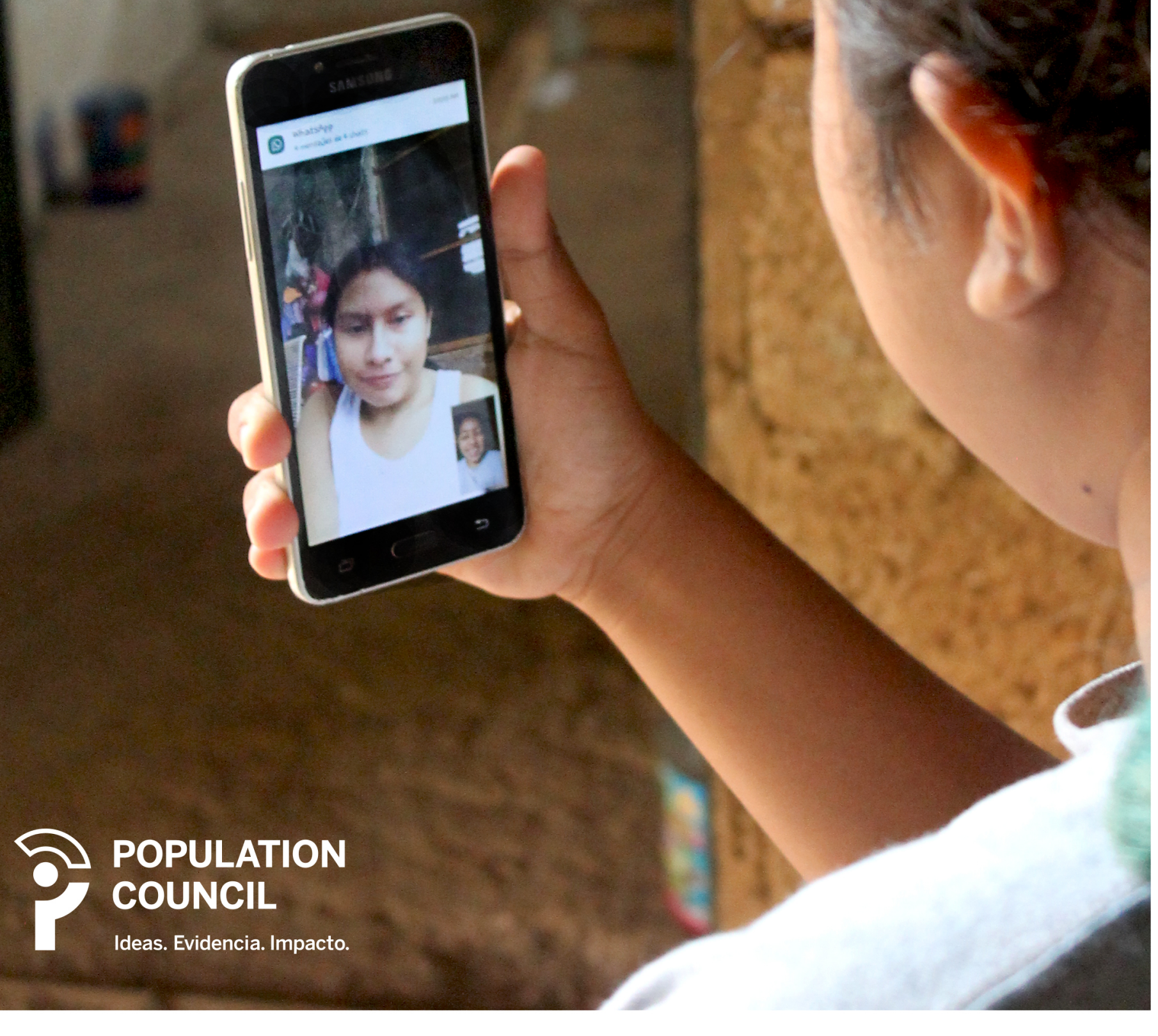




\section{Agradecimientos}

Agradecemos a la Fundación W.K. Kellogg y especialmente a Quetzalli Sotelo y Alejandra Garduño por el apoyo, diseminación e impulso que le dieron a este estudio. Sin su apoyo constante no hubiera sido posible colaborar con tantas organizaciones y contar con las respuestas de tantas personas en las distintas comunidades.

Agradecemos también la colaboración y participación activa de Diana Navarro y de las seis mentoras de Abriendo Futuros, cuyas aportaciones a las encuestas nos ayudaron a contextualizar mejor las preguntas y respuestas y que sin su apoyo para la diseminación y realización de encuestas en ocho comunidades de seis municipios en Yucatán no nos hubiera sido posible llegar a tantas y tantos participantes. Gracias a Angélica Chab (mentora en Mayapán), Cecilia Medina (mentora en Chacskinín), Susana Guzmán (mentora en Tixméhuac), Suemi Chan (mentora en Cantamayec), Lilia Cano (mentora en Maní) y Silvia Chan (mentora en Teabo).

También agradecemos los valiosos aportes a la metodología del estudio, a las encuestas y al análisis de resultados de Ligia Vera, Margarita Zarco, Miguel Güemez y Gloria Uicab, académicas y académico de la Universidad Autónoma de Yucatán (UADY). El profundo conocimiento que tienen sobre la población que vive en las comunidades indígenas del sur de Yucatán fueron fundamentales para mejorar varios aspectos el estudio.

Por otro lado, sin la colaboración de las distintas organizaciones en Chiapas y Yucatán que apoyaron en la diseminación y realización de encuestas en la población de las distintas comunidades, no nos hubiera sido posible llevar a cabo el estudio. A continuación mencionamos cada una de las organizaciones con las que estuvimos en comunicación y que colaboraron en la aplicación de las encuestas:

Yucatán: Kookay A.C., Educe A.C., Educe Sociedad Cooperativa de R.L., Ko'ox Tani A.C., Agencias de Desarrollo Humano Local, Servicios Humanitarios en Salud Sexual y Reproductiva A.C., GT Consultores, PNUD y a la Fundación de Desarrollo Rural en Pro de la Mujer.

Chiapas: AID to Artisans México, Chieltik, ONG Impacto A.C., Centro de Experimentación para el Desarrollo Comunitario Tzeltal A.C., Centro de Investigaciones en Salud de Comitán, Casa de la Mujer Indígena de Guaquitepec A.C. y ACAS A.C.

Asimismo, agradecer a todas las personas que aceptaron participar en el estudio y que contestaron la encuesta. Esperamos que los resultados aquí presentados puedan ser de utilidad para identificar distintas áreas de oportunidad en las diferentes comunidades que puedan apoyar en la disminución del impacto de la pandemia de COVID-19. 


\section{Contenido}

1. Resumen Ejecutivo ........................................................................................................ 3

2. Introducción ......................................................................................................... 9

3. Metodología del Estudio .................................................................................. 14

4.Presentación de resultados Yucatán ................................................................... 17

5.Presentación de resultados Chiapas .................................................................. 33

6. Recomendaciones y consideraciones finales .................................................... 48

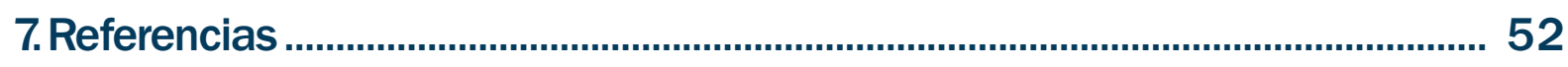




\section{Puntos Clave}

- Al 15 de julio, en México había un total de 317,635 casos confirmados de COVID-19 y 36,906 defunciones. En Yucatán, a esta misma fecha, se habían confirmado 6,674 casos (2.1\% del total de casos) y 612 defunciones (1.6\% del total). En Chiapas, había 5,308 casos confirmados de COVID-19 (1.6\% del total) y 786 defunciones $(2.1 \%$ del total).

- Tanto en Chiapas como en Yucatán, se identifican como principales grupos en riesgo de presentar complicaciones graves y/o muerte por COVID-19 a las personas mayores de 60 años y personas con alguna comorbilidad. Los síntomas más identificados son fiebre, falta de aire y dolor de cabeza. Sin embargo, se observa un menor nivel de conocimientos sobre otros grupos de riesgo (mujeres embarazadas, menores de 5 años y personas con VIH) y sobre síntomas leves asociados a COVID-19. En Chiapas, la población adolescente muestra un mayor desconocimiento de la sintomatología de COVID-19 y de las medidas de prevención en comparación con la población adulta.

- Se identifica un menor conocimiento e intención de uso del cubrebocas, así como de mantener el distanciamiento social, en comparación con otras medidas de prevención entre la población encuestada.

- Más del $80 \%$ de la población adulta y $60 \%$ de la población adolescente en Yucatán expresó un grado de preocupación importante sobre la pandemia en comparación con $53.7 \%$ de la población adulta y $9.0 \%$ de las y los adolescentes en Chiapas.

- Tanto en Chiapas como en Yucatán, se identifica que la inseguridad alimentaria, la menor oportunidad laboral y la pérdida de trabajo son las principales preocupaciones. Un mayor porcentaje de mujeres identificó sentirse preocupadas por el rezago educativo de sus hijos e hijas, en comparación con los hombres.

- Los medios de comunicación en los que más se tienen confianza varían entre estados, entre personas adultas y adolescente y entre mujeres y hombres. En ambos estados se observa un bajo porcentaje de personas que confían en las redes sociales como medio de comunicación para informarse sobre el COVID-19.

- Más del 50\% de la población adulta encuestada en Yucatán identifica haber perdido su trabajo o principal fuente de ingreso desde el inicio de la pandemia en comparación con $31.2 \%$ de la población encuestada.

- Aproximadamente un 25\% de las y los adolescentes en Chiapas y Yucatán identifican no seguir estudiando en casa desde el inicio de la pandemia. El grupo con mayor deserción reportada son los hombres adolescentes en Chiapas. 75\% de las y los adolescentes, en ambos estados, no cuentan con acceso a internet en sus casas.

\section{Caracterización de la población encuestada}

En total, 295 personas originarias de $17 \mathrm{mu}$ nicipios fueron encuestadas en Yucatán: 168 personas adultas (65.2\% mujeres y $34.8 \%$ hombres), 100 adolescentes (75.0\% mujeres y $25.0 \%$ hombres) y 27 autoridades comunitarias ( $55.5 \%$ mujeres y $44.4 \%$ hombres). La mediana de la edad en la población adulta fue de 32.5 años (rango: 18-81), de las autoridades comunitarias de 34 años (rango: 21-51 años) y el promedio de edad en la población adolescente fue de 15.2 años $(\mathrm{DE} \pm 1.0) .88 .4 \%$ de las personas adultas eran hablantes de lengua indígena en comparación con $64.8 \%$ de las y los adolescentes.

En Chiapas, se encuestó a un total de 83 personas originarias de 15 municipios: 56 personas adultas $(71.4 \%$ mujeres y $28.6 \%$ hombres), 22 adolescentes (59.1\% mujeres y $40.9 \%$ hombres) y cinco autoridades comunitarias. La mediana de la edad en la población adulta fue de 28 ańos (rango: 19-48) y el promedio de edad en la población adolescente fue de 16.3 años (DE \pm 0.7$) .87 .5 \%$ de las personas adultas eran hablantes de lengua indígena en comparación con $86.3 \%$ de las y los adolescentes. 


\section{México:}

317,635 casos

36,906 muertes

Al 15 de julio de 2020.

Fuente: Dirección General de

Epidemiología, Secretaría de Salud,

México.

\section{Conocimientos, actitudes y prácticas relacionadas con COVID-19}

- $91.0 \%$ de las personas adultas y $77.2 \%$ de las y los adolescentes en Yucatán y 71.4\% de las personas adultas y $77.2 \%$ de las y los adolescentes en Chiapas identificaron a las personas mayores de 60 ańos como un grupo en riesgo de sufrir complicaciones por el COVID-19. Menos del 50\% en ambos estados y en todos los grupos encuestados identificaron a las mujeres embarazadas, las y los niños menores de 5 ańos y las personas que viven con VIH como un grupo de riesgo.

- Los síntomas de COVID-19 que son identificados en mayor grado por la población encuestada son la fiebre, la falta de aire y el dolor de cabeza. En promedio, poco más del 40\% identifica síntomas leves de COVID-19 (rinorrea, anosmia, tos seca, estornudos, síntomas en piel y mialgias).

- En casi todos los grupos, entre un 37.0\%$40.4 \%$ de la población cree que el rociar el cuerpo con alcohol o cloro puede eliminar de la piel al SARS-CoV-2.

- $82.7 \%$ y $53.5 \%$ de las personas adultas en Yucatán y Chiapas y 64.6\% y 9.0\% de adolescentes, respectivamente, identifican sentirse muy preocupadas por la pandemia. 29.6\% de las autoridades comunitarias en Yucatán percibe que el riesgo de que alguien en su comunidad tenga o se contagie con el SARS-CoV-2 es alto.

- Menos del 40\% de la población adulta en ambos estados y menos de 5 de cada 10 adolescentes identificaron que en caso de presentar síntomas de COVID-19 utilizarían cubrebocas.

- Las principales preocupaciones en la población adulta encuestada en ambos estados con respecto al impacto de la pandemia son la inseguridad alimentaria, la menor oportunidad laboral y la pérdida del trabajo. Una mayor proporción de mujeres identifica sentirse preocupada por el rezago escolar de sus hijos e hijas, por no poder vender productos locales y por perder los apoyos del gobierno, en comparación con los hombres.

- Sobre la confianza en los medios de comunicación, en Yucatán se identifica que los hombres adultos confían más en las conferencias oficiales diarias, mientras que las mujeres adultas y las y los adolescentes confían más en los programas de televisión y noticieros. En Chiapas, los hombres adultos también confían más en las conferencias oficiales diarias, las mujeres adultas en los programas de radios, los adolescentes en el centro de salud y las adolescentes en los programas de radio y en el centro de salud.

\section{Impacto de la pandemia en distintas dimensiones de la} vida de las y los participantes

- $10.2 \%$ y $5.2 \%$ de las mujeres y hombres adultos y $15.3 \%$ de las adolescentes y $22.2 \%$ de los adolescentes en Yucatán identificaron no haber consumido su desayuno, comida y/o cena en la última semana debido a que no había suficiente alimento para toda la familia, en comparación con $17.5 \%$ de las mujeres adultas, 20.2\% de las adolescentes y $8.0 \%$ de los adolescentes en Chiapas. Ningún hombre adulto en Chiapas refirió haber estado en esta situación.

- $51.4 \%$ de las mujeres adultas y $63.1 \%$ de los hombres adultos en Yucatán identificaron 


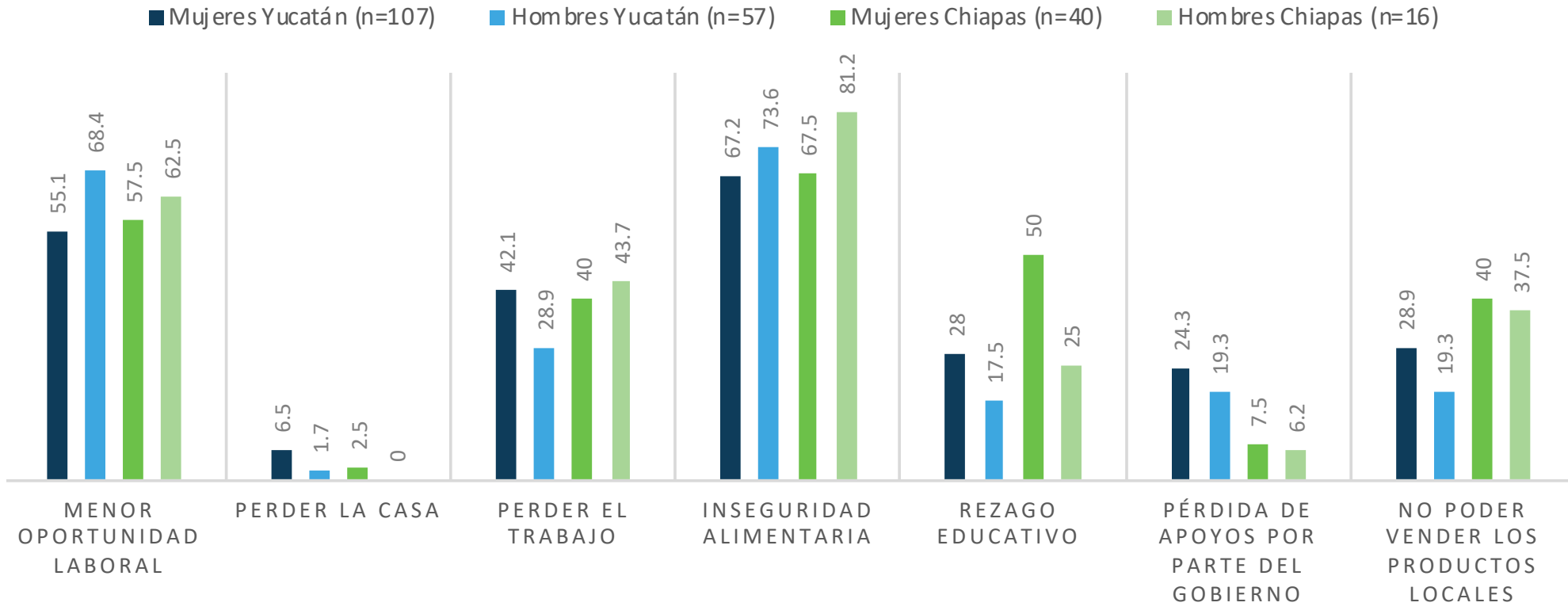

Porcentaje de la población adulta encuestada, por sexo y estado, de acuerdo con las principales preocupaciones sobre el impacto de la pandemia a nivel individual y comunitario.

haber perdido su trabajo y/o principal fuente de ingreso desde el inicio de la pandemia, en comparación con $37.5 \%$ de las mujeres adultas y $25.0 \%$ de los hombres adultos en Chiapas

- $31.4 \%$ de las mujeres y $23.2 \%$ de los hombres en Yucatán y 35.0\% de las mujeres y $46.6 \%$ de los hombres identificaron contar con ahorros. En ambos estados, un mayor porcentaje de hombres en comparación con mujeres indicaron que estos ahorros les alcanzarían para sostener a la familia por un periodo mayor a un mes.

- Menos del 50\% de las personas adultas en ambos estados identificaron que producen suficiente cosecha $y / 0$ tienen suficientes animales de patio para consumo propio.

- En ambos estados, son las mujeres las que realizan en mayor porcentaje el trabajo relacionado con el cuidado del hogar $(73.0 \%$ para el caso de Yucatán y $69.0 \%$ para Chiapas).

- $75.6 \%$ de las adolescentes y 73.9\% de los adolescentes en Yucatán indicaron que siguen estudiando en casa desde el inicio de la pandemia y el cierre de las escuelas, en comparación con $75.0 \%$ de las adolescentes y $62.5 \%$ de los adolescentes en Chiapas.

- En ambos estados, las adolescentes perciben recibir más apoyo en casa para resolver dudas relacionadas con la escuela, en comparación con los hombres.

- En promedio, 75\% de las y los adolescentes en ambos estados no cuentan con acceso a internet en sus casas.

- Se observa que, en general, las adolescentes han aprendido más cosas y refieren haber tenido más experiencias positivas en comparación con los adolescentes. Las principales actividades que han aprendido las adolescentes son cocinar, hacer labores el hogar, cuidar de otras personas y hacer artesanías. Las actividades que han aprendido los hombres son la milpa y siembra, el cuidado de los animales de patio y sobre apicultura, principalmente.

- En Yucatán, las adolescentes comparten con mayor frecuencia sus sentimientos con respecto a la pandemia en comparación con los adolescentes $(37.3 \%$ y $33.3 \%$, respectivamente). En Chiapas los adolescentes comparten con mayor frecuencia sus sentimien- 


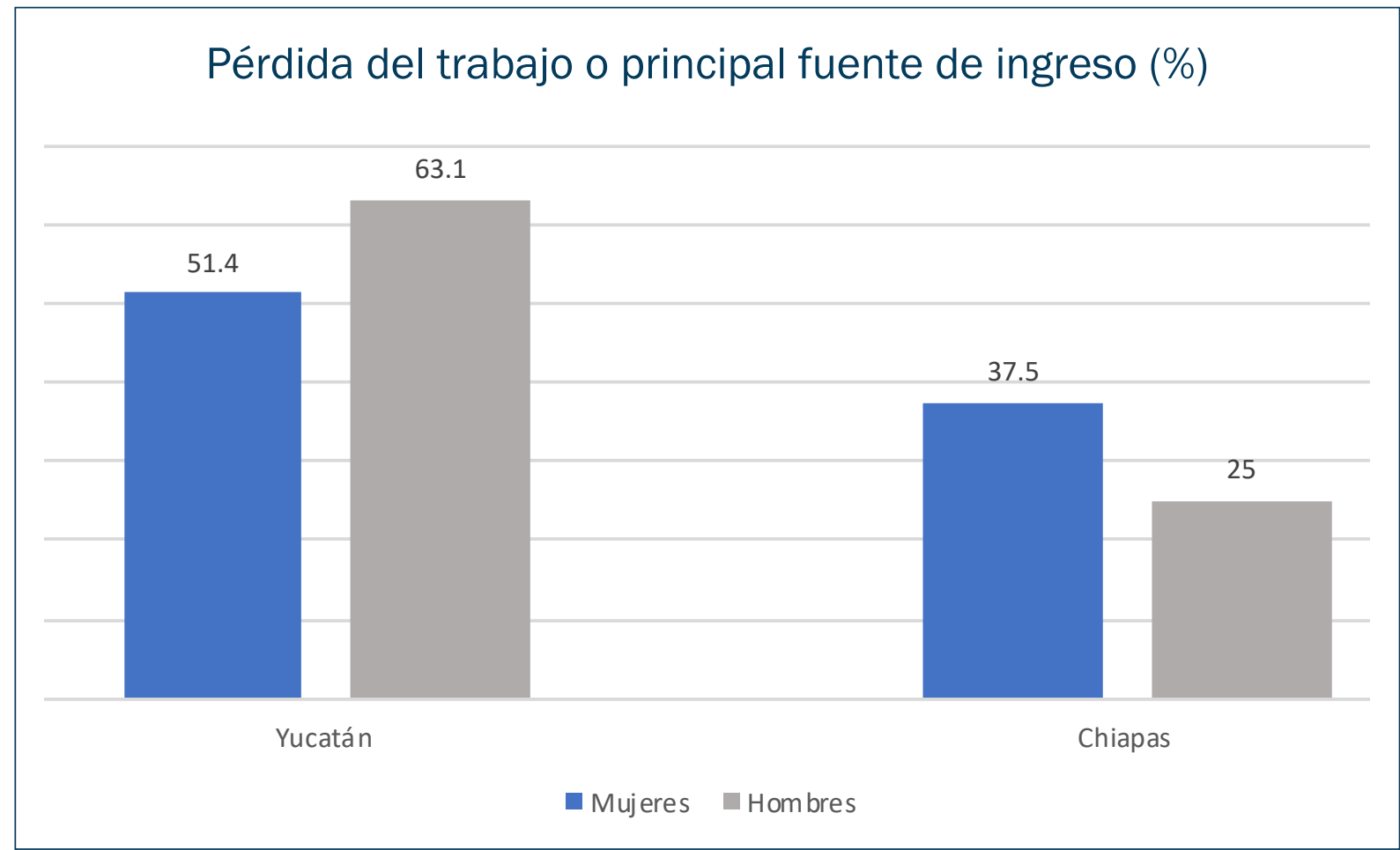

tos en comparación con las mujeres $(11.1 \%$ y $7.6 \%$, respectivamente). Las figuras féminas de la familia son en las que se confía en mayor porcentaje para compartir y hablar sobre estos sentimientos.

\section{Recomendaciones}

- Incrementar el conocimiento de la población adulta, adolescente y de las autoridades comunitarias en dimensiones clave como: los grupos de riesgo, los síntomas más comunes y no solamente los síntomas que indican enfermedad grave y las medidas de prevención clave para evitar contactos de riesgo (lavado de manos adecuado, uso correcto de cubrebocas, sana distancia y la limpieza de superficies, entre otros).

- Incrementar el conocimiento sobre las medidas de prevención apoyadas en evidencia y alertar sobre las creencias que no estén soportadas por evidencia empírica (e.j. rociar el cuerpo con alcohol y tomar dióxido de carbono), que pueden llevar al retraso en atención médica y daños a la salud.

- Diseñar estrategias de comunicación de ries- gos que respondan a las necesidades de la población, pero también a sus preferencias en cuanto a medios de comunicación e idioma de preferencia, incluyendo la necesidad de integrar la perspectiva intercultural en todas las comunicaciones. Analizar las estrategias de acuerdo con la edad y al sexo de las personas que son el objetivo de la campaña.

- Reforzar las estrategias de comunicación de COVID-19 y las medidas de prevención en población adolescente y jóvenes, ya que, aunque no es una población considerada en riesgo para complicaciones graves y/o muerte por COVID-19, es una población que es igual de susceptible de infectarse y de transmitir el virus a poblaciones en mayor riesgo.

- Generar y difundir protocolos de aislamiento de casos sintomáticos que sean sencillos y factibles de implementar en hogares que solo cuenten con una habitación o en los cuáles se comparta el baño entre varios familiares.

- Reforzar los protocolos de atención médica y referencia de casos sintomáticos de COVID-19 en las comunidades, para evitar duplicación de esfuerzos, atención médica 


\section{Continuidad de los estudios desde el inicio de la pandemia \%}

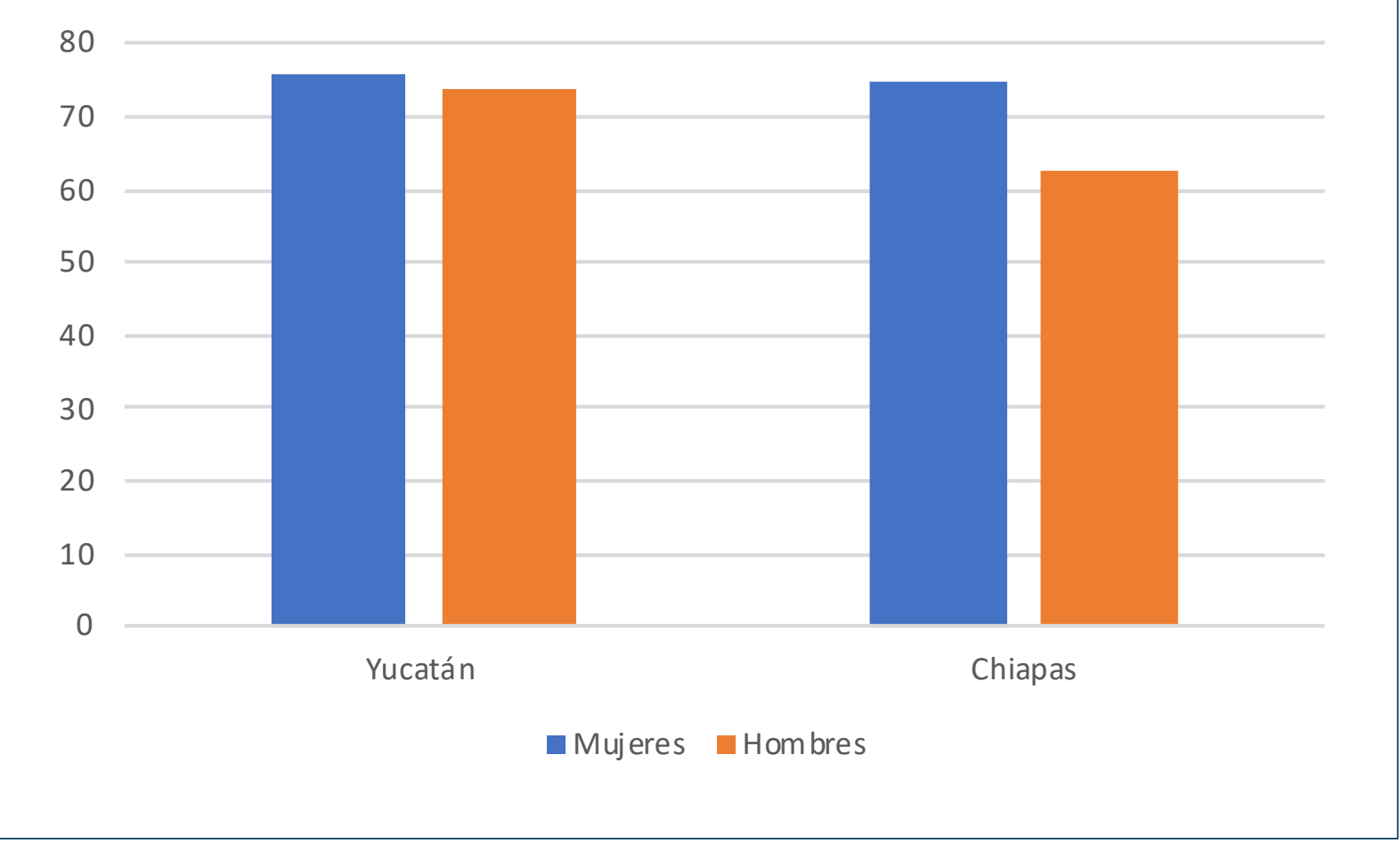

tardía y saturación de unidades de salud.

- Trabajar en coordinación gobierno y organizaciones de la sociedad civil para implementar estrategias de resiliencia familiares y comunitarias que disminuyan el impacto económico de la pandemia en estas comunidades. Por ejemplo, estrategias de educación financiera y ahorro, apoyos para mejorar las estrategias educativas en jóvenes, trueque, cultivo de traspatio para venta y autoconsumo y promoción de estrategias de comercio justo para la venta de artesanías y otros insumos producidos localmente en las comunidades.

- Importancia del derecho al acceso al internet para todas y todos, ya que es una herramienta que permite expandir las oportunidades y estrategias de resiliencia en la población.

- Enfoque en el impacto diferenciado de la pandemia y en estrategias de resiliencia diferenciadas entre hombres y mujeres. Un ejemplo, es la sobrecarga de trabajo no remunerado para mujeres.

- Importancia de incrementar el conocimiento sobre las distintas violencias hacia las mujeres y niñas y la implementación de protocolos de prevención, atención y referencia oportunos para los casos de violencia en esta población. 


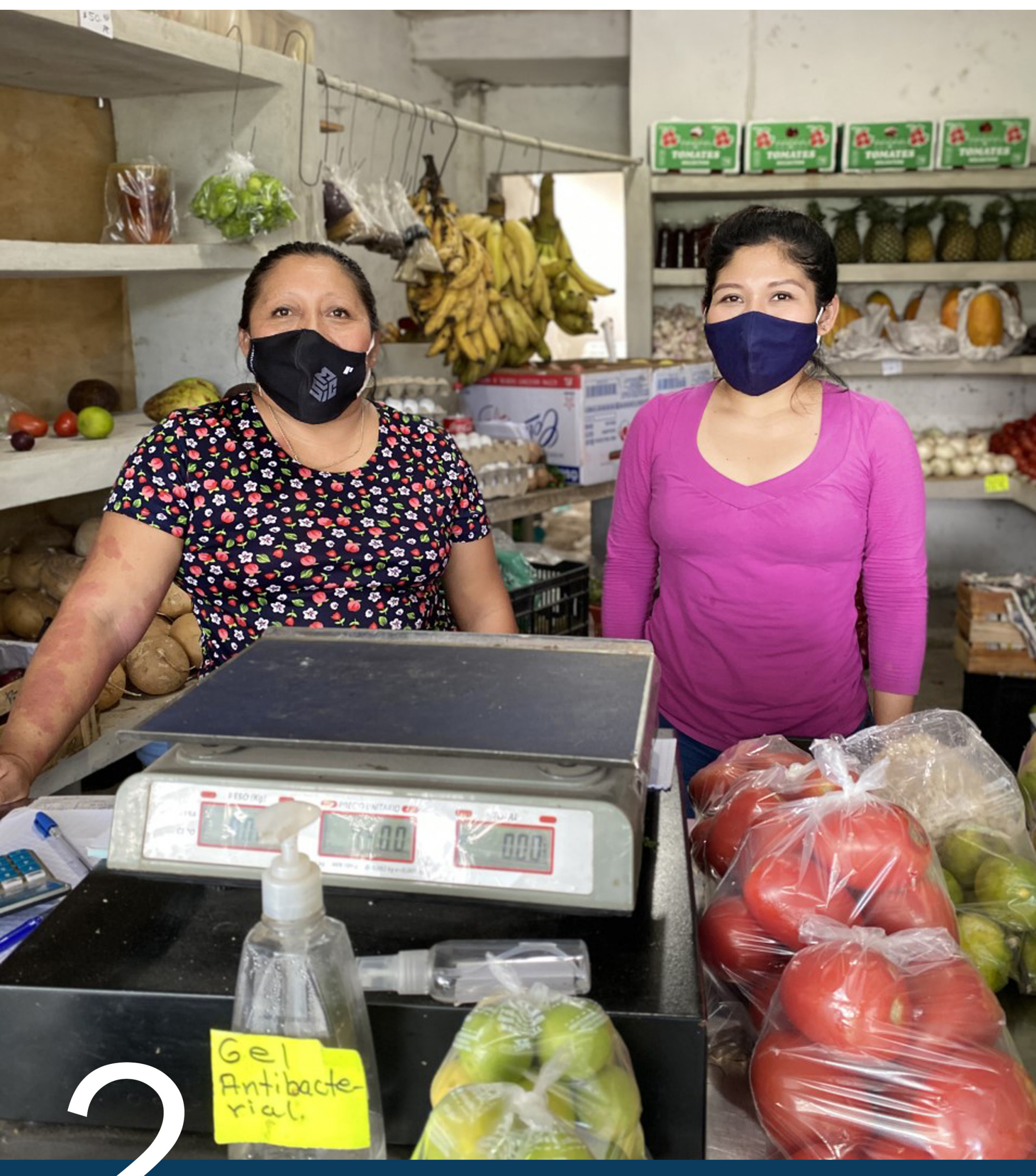




\section{Características sociodemográficas de los estados y municipios encuestados}

Los estados de Yucatán y Chiapas se encuentran localizados en la región sur de México. Yucatán cuenta con un total de 2,097,175 habitantes (51.0\% mujeres y $49.0 \%$ hombres) de acuerdo a la Encuesta Intercensal 2015 (1). El grado de marginación del estado así como el grado de rezago social son clasificados como altos. Del total de municipios (106), $10(9.43 \%)$ son clasificados con un grado de marginación muy alto y $23(21.7 \%)$ con un grado de marginación alto (2). En la siguiente tabla, se muestra el total de población, grado de marginación y rezago municipal, así como si más del 25\% de la población del municipio vive en pobreza extrema de los municipios en los cuales se realizaron las encuestas:

\begin{tabular}{|c|c|c|c|c|}
\hline Municipio & $\begin{array}{c}\text { Población } \\
\text { total } \\
(2015)^{1}\end{array}$ & $\begin{array}{l}\text { Porcentaje de la } \\
\text { población en } \\
\text { pobreza } \\
\text { extrema } \\
(2015)^{2}\end{array}$ & $\begin{array}{l}\text { Porcentaje de la } \\
\text { población con tres } \\
\text { o más carencias } \\
\text { sociales } \\
(2015)^{2}\end{array}$ & $\begin{array}{c}\text { Porcentaje de la } \\
\text { población que habla } \\
\text { una lengua indígena } \\
\qquad(2015)^{2}\end{array}$ \\
\hline Cantamayec & 2,519 & 16.6 & 51.4 & $85.2 \%$ \\
\hline Chacskinkín & 3,015 & 38.1 & 59.0 & $91.8 \%$ \\
\hline Chumayel & 3,308 & 29.1 & 51.8 & $82.7 \%$ \\
\hline Maní & 5,637 & 22.6 & 46.3 & $77.4 \%$ \\
\hline Mayapán & 3,700 & 35.8 & 55.6 & $98.0 \%$ \\
\hline Mérida & 892,363 & 1.8 & 12.4 & $10.2 \%$ \\
\hline Muna & 12,722 & 13.7 & 49.8 & $44.5 \%$ \\
\hline Oxcutzcab & 31,202 & 18.4 & 49.6 & $60.4 \%$ \\
\hline Peto & 25,264 & 21.7 & 47.5 & $60.9 \%$ \\
\hline Sacalum & 4,819 & 23.4 & 48.4 & $62.8 \%$ \\
\hline Tahdziu & 5,111 & 48.0 & 66.7 & $98.2 \%$ \\
\hline Teabo & 6,551 & 28.1 & 57.2 & $79.1 \%$ \\
\hline Tekax & 42,440 & 12.1 & 41.6 & $58.3 \%$ \\
\hline Ticul & 40,161 & 11.3 & 44.2 & $41.1 \%$ \\
\hline Tixméhuac & 4,813 & 32.7 & 60.6 & $88.3 \%$ \\
\hline Valladolid & 80,313 & 12.1 & 43.1 & $55.6 \%$ \\
\hline Yaxcabá & 15,203 & 20.3 & 61.8 & $75.2 \%$ \\
\hline \multicolumn{5}{|c|}{$\begin{array}{l}\text { Referencias } \\
\text { 1. Instituto Nacional de Estadística y Geografía. Encuesta Intercensal 2015. México. Disponible en: } \\
\text { https://www.inegi.org.mx/programas/intercensal/2015/ } \\
\text { 2. Consejo Nacional de Evaluación de la Política de Desarrollo Social (CONEVAL). Medición de la pobreza, Estados Unidos Mexicanos, } \\
\text { 2010-2015. Indicadores de pobreza por municipio. México. } \\
\text { Disponible en: https://www.coneval.org.mx/Medicion/Paginas/AE_pobreza_municip al.aspx }\end{array}$} \\
\hline
\end{tabular}

En Yucatán, para 2015, 575,740 habitantes de 3 años y más hablaban alguna lengua indígena (28.8\%) (1). La lengua indígena predominante es el Maya (98.7\%), seguida del Chol (0.2\%). De acuerdo con el Censo 2010, el promedio de habitantes por hogar era de 3.9 (2). La tasa de alfabetización, en 2015 , era del $88.3 \%$ para la población de $6-14$ ańos y del $91.8 \%$ para la población de 15 años y más. Para este mismo año, 13.4\% de la población no se encontraba afiliada a un servicio de salud (1). 
Por otro lado, Chiapas cuenta con una población total de 5,217,908 habitantes $(51.4 \%$ mujeres y 48.6\% hombres) de acuerdo a la Encuesta Intercensal 2015 (1). El grado de marginación del estado así como el grado de rezago social son clasificados como muy altos. Del total de municipios (118), 48 (40.6\%) son clasificados con un grado de marginación muy alto y 39 $(33.0 \%)$ con un grado de marginación alto (4). En la siguiente tabla, se muestra el total de población, grado de marginación y rezago municipal, así como si más del $25 \%$ de la población del municipio vive en pobreza extrema de los municipios en los cuales se realizaron las encuestas:

\section{Características sociodemográficas de los municipios en Chiapas que participaron en la encuesta, 2015.}

\begin{tabular}{|c|c|c|c|c|}
\hline Municipio & $\begin{array}{l}\text { Población } \\
\text { total } \\
(2015)^{1}\end{array}$ & $\begin{array}{l}\text { Porcentaje de la } \\
\text { población en } \\
\text { pobreza } \\
\text { extrema } \\
(2015)^{2}\end{array}$ & $\begin{array}{l}\text { Porcentaje de la } \\
\text { población con tres } \\
\text { o más carencias } \\
\text { sociales } \\
(2015)^{2}\end{array}$ & $\begin{array}{c}\text { Porcentaje de la } \\
\text { población que habla } \\
\text { una lengua indígena } \\
(2015)^{2}\end{array}$ \\
\hline Aldama & 6,712 & 54.4 & 55.9 & $99.5 \%$ \\
\hline Amatenango del Valle & 9,913 & 54.2 & 57.2 & $76.5 \%$ \\
\hline Chenalhó & 39,648 & 77.0 & 80.5 & $98.5 \%$ \\
\hline Chilón & 127,914 & 70.0 & 74.7 & $95.6 \%$ \\
\hline Huixtán & 23,625 & 60.3 & 69.2 & $90.2 \%$ \\
\hline Las Margaritas & 122,821 & 51.1 & 60.4 & $41.9 \%$ \\
\hline Ocosingo & 218,893 & 50.7 & 62.2 & $77.6 \%$ \\
\hline Oxchuc & 48,126 & 75.7 & 80.7 & $97.9 \%$ \\
\hline San Andrés Larráinzar & 23,889 & 52.5 & 55.7 & $99.4 \%$ \\
\hline San Cristóbal de las Casas & 209,591 & 16.8 & 27.6 & $32.1 \%$ \\
\hline San Juan Canuc & 34,829 & 77.7 & 80.7 & $99.7 \%$ \\
\hline Santiago el Pinar & 3,684 & 54.7 & 58.7 & $99.8 \%$ \\
\hline Sitalá & 13,844 & 66.2 & 69.9 & $95.4 \%$ \\
\hline Tenejapa & 43,593 & 59.6 & 65.5 & $99.2 \%$ \\
\hline Zinacantán & 41,112 & 61.5 & 67.9 & $99.0 \%$ \\
\hline \multicolumn{5}{|c|}{$\begin{array}{l}\text { Referencias: } \\
\text { 1. Instituto Nacional de Estadística y Geografía. Encuesta Intercensal 2015. México. Disponible en: } \\
\text { https://www.inegi.org.mx/programas/intercensal/2015/ } \\
\text { 2. Consejo Nacional de Evaluación de la Política de Desarrollo Social (CONEVAL). Medición de la pobreza, Estados Unidos Mexica- } \\
\text { nos, 2010-2015. Indicadores de pobreza por municipio. México. Disponible en: } \\
\text { https://www.coneval.org.mx/Medicion/Paginas/AE_pobreza_municipal.aspx } \\
\text { 3. Instituto Nacional de Estadística y Geografía. Panorama sociodemográfico de Chiapas. 2015. Disponible en: http://internet. } \\
\text { contenidos.inegi.org.mx/contenidos/Productos/prod_serv/contenidos/espanol/bvinegi/productos/nueva_estruc/inter_censal/ } \\
\text { panorama/702825082154.pdf }\end{array}$} \\
\hline
\end{tabular}

Los Altos de Chiapas, donde se encuentra la mayor parte de los municipios donde se realizó la encuesta (Aldama, Amatenango del Valle, Chenalhó, Huixtán, Oxchuc, San Andrés Larráinzar, San Cristóbal de las Casas, San Juan Canun, Santiago el Pinar, Tenejapa y Zinacantán), cuenta con dos grupos étnicos sobresalientes: Tsotsil y Tseltal. La región tiene un total de 601,190 habitantes (68.0\%), de los cuales 408,958 hablan alguna lengua indígena. De acuerdo con datos del CONEVAL, $88.0 \%$ de las personas que viven en esta región se encuentra en situación de pobreza ( $56.0 \%$ en pobreza extrema y $32 \%$ en pobreza moderada). Por otro lado, $42.0 \%$ de la población en 2010 se encontraba en rezago educativo, $34.0 \%$ no contaba con acceso a servicios de salud, $92.0 \%$ no tenía acceso a seguridad social, $77 \%$ no contaba con todos los servicios básicos en su vivienda y $39 \%$ no contaban con un adecuado acceso a la alimentación. En este mismo año, el promedio de habitantes por hogar era de 4.93 (por encima del promedio estatal de 4.1 habitantes) (5). 


\section{COVID-19 y Pueblos Indígenas}

Hasta el 15 de julio, en México había un total de 317,635 casos confirmados de COVID-19 y 36,906 defunciones. En Yucatán, a esta misma fecha, se habían confirmado 6,674 casos (2.1\% del total de casos) y 612 defunciones (1.6\% del total). En Chiapas, había 5,308 casos confirmados de COVID-19 (1.6\% del total) y 786 defunciones (2.1\% del total) $(7,8)$. Los municipios con más casos activos en Yucatán son: Mérida (3,859 casos), Valladolid (414 casos), Kanasín (267 casos), Umán (266 casos), Ticul (224 casos), Progreso (133 casos), Tekax (116 casos) y Tizimín (105 casos) (9). En Chiapas, los municipios con más casos confirmados son Tuxtla Gutiérrez (2,051 casos), Tapachula (767 casos), San Cristóbal de las Casas (294 casos), Comitán de Domínguez (126 casos), Chiapa de Corzo (125 casos), Tonalá (117 casos), Huixtla (89 casos) y Palenque (85 casos) (10).

Hasta el 18 de julio, la Secretaría de Salud había identificado 4,643 casos en población indígena. Los estados con más número de casos en esta población son Yucatán (745 casos), Oaxaca (479 casos), el Estado de México (435 casos) y la Ciudad de México (355 casos). Con respecto a las defunciones por COVID-19 en esta población, se han reportado un total de 733 en todo el territorio mexicano. Los estados con más defunciones registradas son Yucatán $(\mathrm{n}=115)$, Oaxaca ( $n=93)$, el Estado de México $(n=79)$ y Quintana Roo $(\mathrm{n}=52)(11)$.

Debido a que los pueblos indígenas tienen más probabilidad de vivir en condiciones de extrema pobreza, además de tener un menor acceso a recursos y servicios para disminuir las consecuencias en salud y los impactos económicos y sociales de la pandemia, es probable que se vean en una mayor situación de vulnerabilidad ante el COVID-19, en particular mujeres y niñas indígenas. Se identifican cuatro principales retos que existen para combatir la pandemia en esta población: (1) falta de confianza de la población indígena en las autoridades (incluyendo autoridades sanitarias) y la incredulidad en la existencia y/o gravedad de la enfermedad, lo cual puede llevar a un repudio del personal de salud encargado de la atención de la pandemia; (2) mayor desinformación y creencia en mitos y medidas de prevención y control que carecen de apoyo empírico, lo cual puede impactar directamente en la implementación de medidas de prevención que han demostrado ser eficaces para disminuir la propagación de la pandemia; (3) el acceso limitado a servicios básicos (e.j. agua y jabón de manos), ahunado a una comunicación deficiente por parte de las autoridades y a una falta de protección financiera y acceso a servicios de salud, puede derivar en un aumento de casos en estas comunidad y en una atención tardía para las personas con síntomas graves; y, (4) como consecuencia del desempleo generalizado, las personas están migrando en grandes cantidades desde las principales ciudades y sitios turísticos a sus comunidades de orígen, lo cual, si no se siguen las medidas de prevención recomendadas, pone en un riesgo elevado de contagio a las comunidades indígenas (12).

\section{Justificación}

La implementación de las medidas de higiene y sana distancia son necesarias para disminuir la propagación del nuevo coronavirus. Sin embargo, las medidas de prevención no son siempre adoptadas por igual por toda la población. Esto puede deberse, entre otros factores, a condiciones de vida y sustento precarias, así como a conocimientos, creencias, actitudes, prácticas y percepciones del riesgo distintas sobre la enfermedad. Además, la situación puede agravarse por la difusión de información falsa sobre COVID-19, incluidas medidas preventivas y tratamientos que no han demostrado ser efectivos contra el nuevo coronavirus (13).

Recolectar información sobre conocimientos, actitudes y prácticas (CAP) de las personas en relación con una enfermedad y en un contexto determinado, puede ser de gran utilidad para la implementación de medidas epidemiológicas de prevención, control y mitigación de forma estratégica. Un ejemplo reciente de la utilidad de estos estudios es la 
respuesta al Ébola en Guinea, África Occidental, en donde la información proveniente de un estudio de CAP permitió identificar percepciones erróneas sobre la prevención y transmisión del virus del Ébola, la necesidad de prevenir el estigma hacia los sobrevivientes y fomentar un manejo más seguro de las prácticas de entierro (14).

Debido a que, como se mencionó anteriormente, los pueblos indígenas se encuentran ante una mayor situación de vulnerabilidad frente a la pandemia de COVID-19, es importante identificar qué es lo que comunidades con un elevado porcentaje de población indígena en Chiapas y Yucatán conoce, piensa y haría ante esta enfermedad, así como identificar el impacto y las acciones implementadas para mitigar los efectos de esta pandemia en distintas dimensiones de la vida de personas adultas y adolescentes que viven en estas comunidades.

\section{Objetivo}

El objetivo del presente estudio fue identificar:

1. Los conocimientos, actitudes y prácticas reportadas por autoridades comunitarias, adolescentes y personas adultas que viven en comunidades rurales indígenas de Chiapas y $\mathrm{Yu}$ catán con respecto a la pandemia del COVID-19.

2. Áreas de oportunidad para mejorar la difusión de información sobre COVID-19 en estas comunidades.

3. Las principales barreras para adoptar medidas preventivas para la disminución del número de casos positivos de COVID-19 en las comunidades.

4. El impacto de la pandemia en distintas dimensiones de la vida de las peronas adultas y las y los adolescentes que viven en estas comunidades.

5. Las acciones implementadas para contrarrestar las consecuencias económicas de la pandemia. 

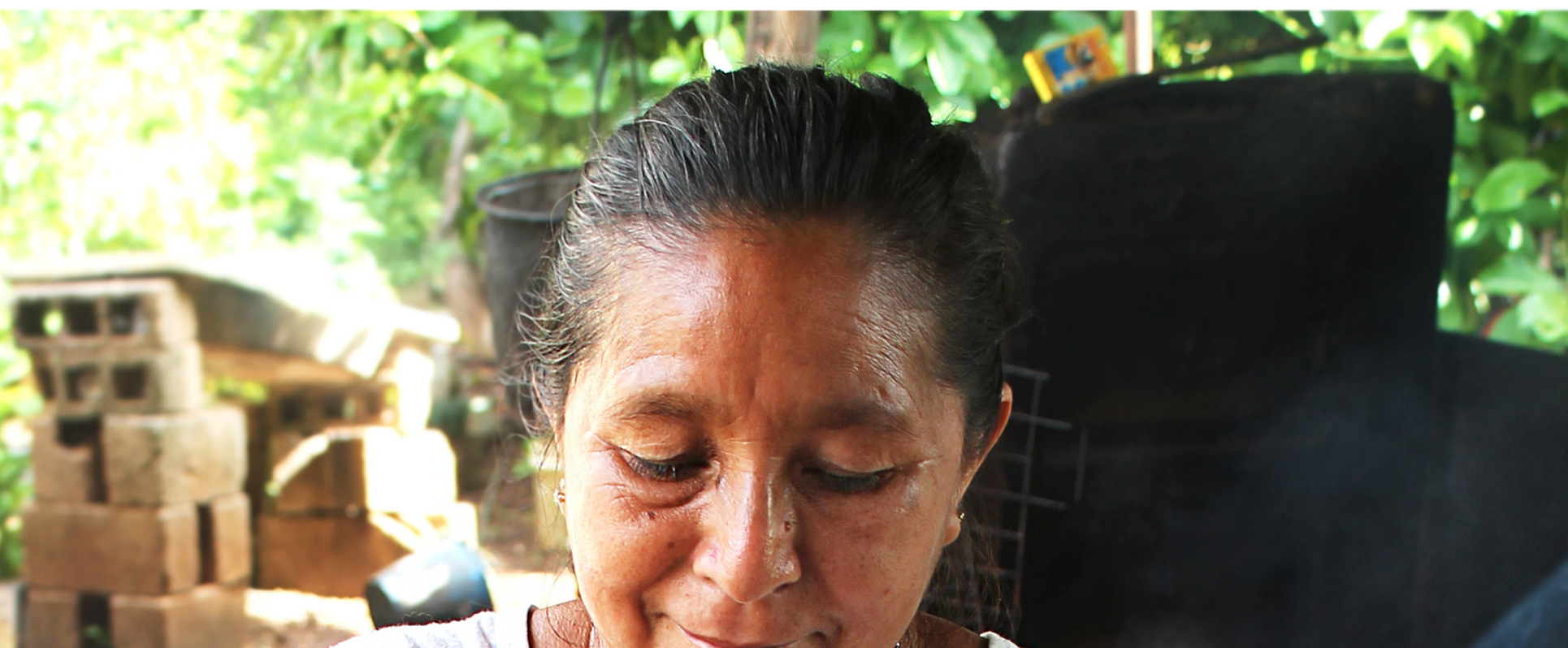
Para cumplir con los objetivos presentados, se implementó un estudio transversal de corte cuantitativo con población adulta, adolescente y autoridades comunitarias en 33 municipios de Chiapas y Yucatán con presencia de población hablante de una lengua indígena. La selección de las comunidades se hizo con base en la presencia de organizaciones de la sociedad civil que estuvieran colaborando con la Fundación W.K. Kellogg Foundation en estos dos estados.

La población objetivo del estudio fueron:

1.Hombres y mujeres adultas (18 años y más);

2.Hombres y mujeres adolescentes de entre 14 y 17 ańos; y,

3.Autoridades comunitarias (autoridades municipales, ejidales, religiosas o parte de un gobierno autónomo).

\section{Selección de la muestra}

Debido a la baja disponibilidad y uso de internet en estas comunidades y a que no se contaba con una lista de beneficiarias y beneficiarios de los programas o proyectos implementados por las organizaciones locales la estrategia de muestreo implementada fue por conveniencia.

\section{Desarrollo del cuestionario}

Se diseñaron tres cuestionarios para cada uno de los grupos poblacionales objetivo del estudio. Las encuestas fueron diseñadas con base en los cuestionarios sobre conocimientos, actitudes y prácticas implementadas por el Population Council en otros países del mundo (Kenya, Bangladesh, India y Guatemala). Académicos y académicas de la Universidad Autónoma de Yucatán (UADY), así como las mentoras del programa Abriendo Futuros, fueron invitados a participar en la revisión del cuestionario, para que este estuviera adaptado a las necesidades y características de la población de Yucatán y Chiapas. Los tres cuestionarios fueron programas en la plataforma Survey Monkey y se generó una liga particular para cada cuestionario ${ }^{1}$.

Antes del inicio de cada cuestionario, se desplegaba el consentimiento y asentimiento informado.

\section{Estrategias de recolección de la información}

Con motivo de las medidas de distanciamiento social, la estrategia principal utilizada para las personas adultas y autoridaes comunitarias fue la aplicación de las encuestas en línea, a través de la plataforma Survey Monkey. Para el caso de las y los adolescentes, y como un mecanismo para proteger sus derechos y, por lo tanto, solicitar tanto el consentimiento informado de un tutor/a legal como el asentimiento de ellas y ellos, la estrategia utilizada en este grupo poblacional fue con encuestas teléfonicas. Las respuestas que brindaban las y los adolescentes eras ingresadas por la o el encuestador a la plataforma. Esta estrategia también fue utilizada para población adulta que no contaba con acceso a internet y/o a una tecnología de la información. Para el caso de algunas comunidades en Chiapas, debido a la muy baja disponibilidad de internet y tecnologías de la información, las encuestas se hicieron presencialmente (siguiendo todas las medidas de prevención para COVID-19 y en los municpios donde el color del semáforo lo permitía).

Para alcanzar a un mayor número de participantes, se invitó a las organizaciones locales que trabajan en estas comunidades a participar en la diseminación y realización de las encuestas. Una invitación personalizada acompañada por un documento que describía el estudio, así como instrucciones sobre cómo se debía aplicar la encuestas dependiendo del grupo poblacional, fueron enviadas a aquellas organizaciones que aceptaron participar. El equipo del Population Council estaba en contacto constante con estas organizaciones para resolver las dudas que se presentaban.

Las encuestas se mantuvieron abiertas durante todo el mes de junio del ańo 2020.

\section{Discusión participativa de los resultados}

Con el objetivo de contextualizar mejor los resultados del estudio y construir sobre las experiencias de las organizaciones de la so- 
ciedad civil que trabajan localmente en estas comunidades, se organizó un webinar para presentar y discutir entre todas y todos los resultados del estudio. En este webinar, participaron 23 representantes de distintas organizaciones de la sociedad civil que trabajan en Chiapas y Yucatán, así como una representante de la Fundación W.K. Kellogg. Se tomaron notas de las participaciones orales y escritas de las y los representantes y se integraron dentro de la sección de recomendaciones y consideraciones finales de este informe.

\section{Limitaciones del estudio}

La primera limitación del estudio es la estrategia de muestreo utilizada, ya que debido a que no fue una muestra representativa, los resultados no pueden ser generalizables al resto de la población que viven en dichas comunidades. Sin embargo, los resultados pueden, por un lado, identificar dimensiones que necesitan estudiarse a mayor detalle $y$, por otro, guiar algunas de las acciones de las organizaciones locales que trabajan en estas comunidades, señalando áreas de oportunidad con respecto a conocimientos, actitudes y prácticas, pero también hacia estrategias que disminuyan el impacto a mediano y largo plazo de la pandemia en estas comunidades.

Una segunda limitación, es el sesgo de selección inherente a la metodología de recolección de la información, ya que la población encuestada es población beneficiaria de uno o varios de los proyectos implementados por las organizaciones locales en las comunidades, por lo cual puede no ser una población similar a la población que no es beneficiaria de estos proyectos. Sin embargo, consideramos que, por lo mismo, la población beneficiaria pudiera estar más informada sobre la pandemia y menos expuesta al impacto de la pandemia en comparación con la población no beneficiara. Es decir, la población no beneficiaria pudiera tener menor conocimiento, implementar en menor grado las medidas y encontrarse más afectada en diversas dimensiones por la pandemia.
Otra limitación es el tamańo de la muestra, sobre todo para el caso de las y los adolescentes y las autoridades comunitarias en Chiapas. Por lo cual, es importante manejar con cautela estos datos y, nuevamente, no generalizar a la población general de adolescentes y autoridades comunitarias estos hallazgos. Asimismo, la información no permite hacer análisis comparativos entre los estados en términos estadísticos.

Por último, durante la aplicación de las encuestas, la tormeta "Cristóbal" impactó en Yucatán y Chiapas, inundando varias comunidades, generando varias pérdidas materiales, reenfocando los esfuerzos de las organizaciones locales hacia la respuesta a necesidades inmediatas derivadas de la tormenta y, por lo tanto, limitando la aplicación de las encuestas. 


\section{I.Perfil sociodemográfico de las personas encuestadas}

En total, 295 personas fueron encuestadas en Yucatán: 168 personas adultas (18 años y más), 100 adolescentes de entre 14 y 18 años y 27 autoridades comunitarias. Las mujeres y hombres adultos eran originarios de 16 municipios, siendo los municipios con mayor participación en este grupo Cantamayec, Teabo, Maní, Yaxcabá y Tixméhuac. Las y los adolescentes encuestados eran originarios de seis municipios, siendo Cantamayec y Mayapán los municipios con mayor participación. Por último, las autoridades comunitarias trabajaban en siete municipios, siendo los dos municipios con mayor número de autoridades encuestadas Teabo y Cantamayec (ver Tabla 1 y Mapa 1 y 2).

\begin{tabular}{|c|c|c|c|}
\hline Municipio & $\begin{array}{c}\text { Personas } \\
\text { adultas } \\
n(\%)\end{array}$ & $\begin{array}{c}\text { Adolescentes } \\
\mathrm{n}(\%)\end{array}$ & $\begin{array}{c}\text { Autoridades } \\
\text { comunitarias } \\
\mathrm{n}(\%)\end{array}$ \\
\hline Cantamayec & $26(15.4)$ & $24(24.0)$ & 7 (25.9) \\
\hline Chacskinkín & $26(15.4)$ & $20(20.0)$ & $2(7.4)$ \\
\hline Chumayel & $1(0.5)$ & 0 & 0 \\
\hline Maní & 19 (11.3) & $12(12.0)$ & $1(3.7)$ \\
\hline Mayapán & $32(19.0)$ & $20(20.0)$ & $5(18.5)$ \\
\hline Mérida & $2(1.1)$ & 0 & $1(3.7)$ \\
\hline Muna & $1(0.5)$ & 0 & 0 \\
\hline Oxcutzcab & $2(1.1)$ & 0 & 0 \\
\hline Peto & $2(1.1)$ & 0 & 0 \\
\hline Sacalum & $1(0.5)$ & 0 & 0 \\
\hline Tahdziu & $2(1.1)$ & 0 & 0 \\
\hline Teabo & $26(15.4)$ & $12(12.0)$ & $10(37.0)$ \\
\hline Tekax & $1(0.5)$ & 0 & 0 \\
\hline Ticul & $2(1.1)$ & 0 & 0 \\
\hline Tixméhuac & $13(7.7)$ & $4(4.0)$ & 0 \\
\hline Valladolid & $1(0.5)$ & 0 & 0 \\
\hline Yaxcabá & $11(6.5)$ & $8(8.0)$ & $1(3.7)$ \\
\hline Total & 168 & 100 & 27 \\
\hline
\end{tabular}

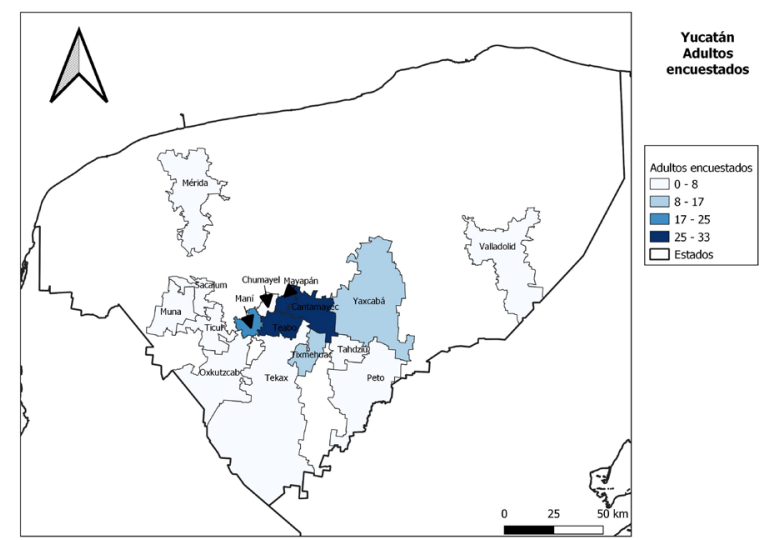

Mapa 1. Municipios participantes. Encuesta a personas adultas, Yucatán. 2020.

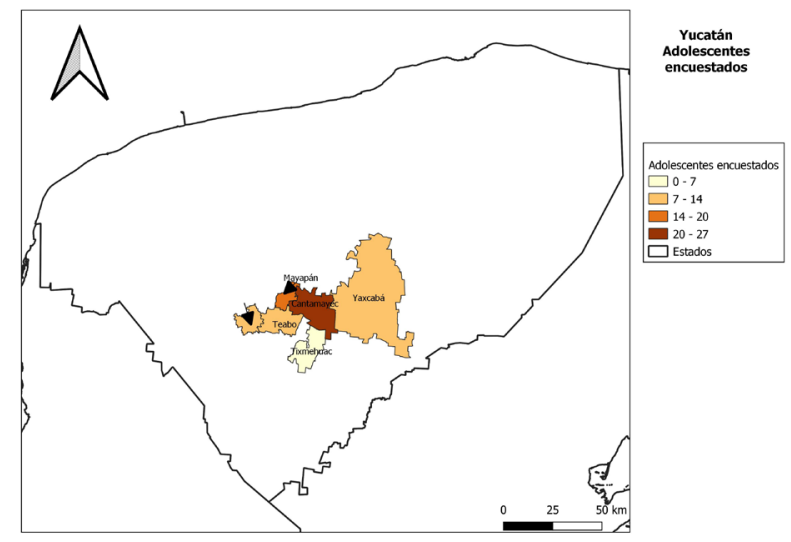

Mapa 2. Municipios participantes. Encuesta a adolescentes, Yucatán. 2020. 


\begin{tabular}{|c|c|c|c|c|}
\hline & $\begin{array}{l}\text { Mujeres adultas } \\
\qquad(n=107)\end{array}$ & $\begin{array}{l}\text { Hombres adultos } \\
\qquad(n=57)\end{array}$ & $\begin{array}{l}\text { Mujeres adolescentes } \\
\qquad(n=75)\end{array}$ & $\begin{array}{l}\text { Hombres adolescentes } \\
\qquad(n=25)\end{array}$ \\
\hline Edad* & $32(18-81)$ & $33(18-72)$ & $15.2(0.9)$ & $15.5(1.0)$ \\
\hline Sexo** & $107(65.2)$ & $57(34.7)$ & $75(75.0)$ & $25(25.0)$ \\
\hline $\begin{array}{l}\text { Hablantes de lengua } \\
\text { indígena** }\end{array}$ & $94(90.3)$ & 49 (85.9) & $43(62.3)$ & $18(72.0)$ \\
\hline Años de escolaridad $* * *$ & $7.7(3.3)$ & $8.1(2.6)$ & $8.4(1.5)$ & 8-7 (1.4) \\
\hline $\begin{array}{l}\text { Número de habitantes } \\
\text { por hogar****}\end{array}$ & $4.7(2-11)$ & $4.9(1-19)$ & No aplica & No aplica \\
\hline \multicolumn{5}{|c|}{$\begin{array}{l}\text { * La edad se presenta como mediana con mínimos y máximos para población adulta y como promedio y desviación estándar para adolescentes. } \\
* * \text { Número absoluto y, entre paréntesis, el porcentaje que representa del total. } \\
* * * \text { Los años de escolaridad están representados como el promedio y la desviación estándar. } \\
* * * * \text { El número de habitantes por hogar se presenta como la mediana con los mínimos y máximos entre paréntesis. }\end{array}$} \\
\hline
\end{tabular}

La mediana de la edad de la población adulta encuestada fue de 32.5 años con un rango de 18 ańos a 81 años y el promedio de edad de la población adolescente fue de 15.2 años ( $\mathrm{DE} \pm 1$ ańo). Para la población adulta, $65.2 \%$ de la población fue mujer y $34.7 \%$ fue hombre y para las y los adolescentes encuestados $75.0 \%$ fue mujer y $25.0 \%$ fue hombre. Un mayor porcentaje de población adulta identificó hablar una lengua indígena $(88.4 \%)$ en comparación con la población adolescente (64.8\%).

Con respecto al número total de personas que habitan en una casa, la mediana fue de 4.7 personas para las mujeres adultas (2-11 personas) y 4.9 para hombres adultos (1-19 personas). Por último, con respecto a nivel educativo, el promedio de años de escolaridad para mujeres adultas fue de 7.7 años $(\mathrm{DE} \pm 3.3$ años) y de 8.1 años $(\mathrm{DE} \pm 3.0$ años) para hombres. En la población adolescente, el promedio de ańos de escolaridad completados fue de 8.4 años ( $\mathrm{DE} \pm 1.5$ años) para mujeres y 8.7 años ( $\mathrm{DE} \pm 1.4$ ańos) para hombres (ver Tabla 2).

Se encuestaron a un total de 27 autoridades comunitarias en 7 municipios con los siguientes perfiles de puesto: Presidente/a municipal, síndico/a, comisario municipal, presidente/a DIF municipal, policía, comandante, regidor/a de salud, tesorero municipal, secretario/a, juez de paz, voluntario/a, médico/a pasante, y párroco. La mediana de edad de las autoridades fue de 34 años con un rango de 21 a 51 años. $44.4 \%$ eran hombres y $55.5 \%$ mujeres.

\section{Conocimientos, actitudes y prácticas relacionadas a la pandemia por COVID-19}

\section{A. Conocimientos}

Las encuestas muestran que la mayoría de la población entrevistada identifica correctamente a los principales grupos en riesgo de tener complicaciones graves y muerte por COVID-19 (ver Figura 1):

- Los adultos mayores; $y$,

- Las personas que tienen otras enfermedades crónicas

Sin embargo, se identifican en menor porcentaje a los menores de cinco ańos $(<30 \%$ en todos los grupos encuestados) y las mujeres embarazadas $(<30 \%$ en personas adultas y adolescentes y menos del $45 \%$ en autoridades). Algunos estudio realizados en otros países han identificado un aumento en la incidencia de síndromes sistémicos (tipo Kawasaki) en niñas y niños, y un aumento en la mortalidad materna asociada a COVID-19, por lo que se están considerando para este análisis como grupos de riesgo. Por otro lado, las personas que viven con VIH y que presentan un sistema inmune deprimido (conteo bajo de células TCD4+) y/o comorbilidades, también se han identificado como un posible grupo que pudiera estar en riesgo de presentar complicaciones graves o muerte por COVID-19. 
Figura 1. Porcentaje de población encuestada que identifica a los grupos en riesgo de complicaciones graves y/o muerte por COVID-19, por grupo encuestado y sexo. Yucatán, 2020.

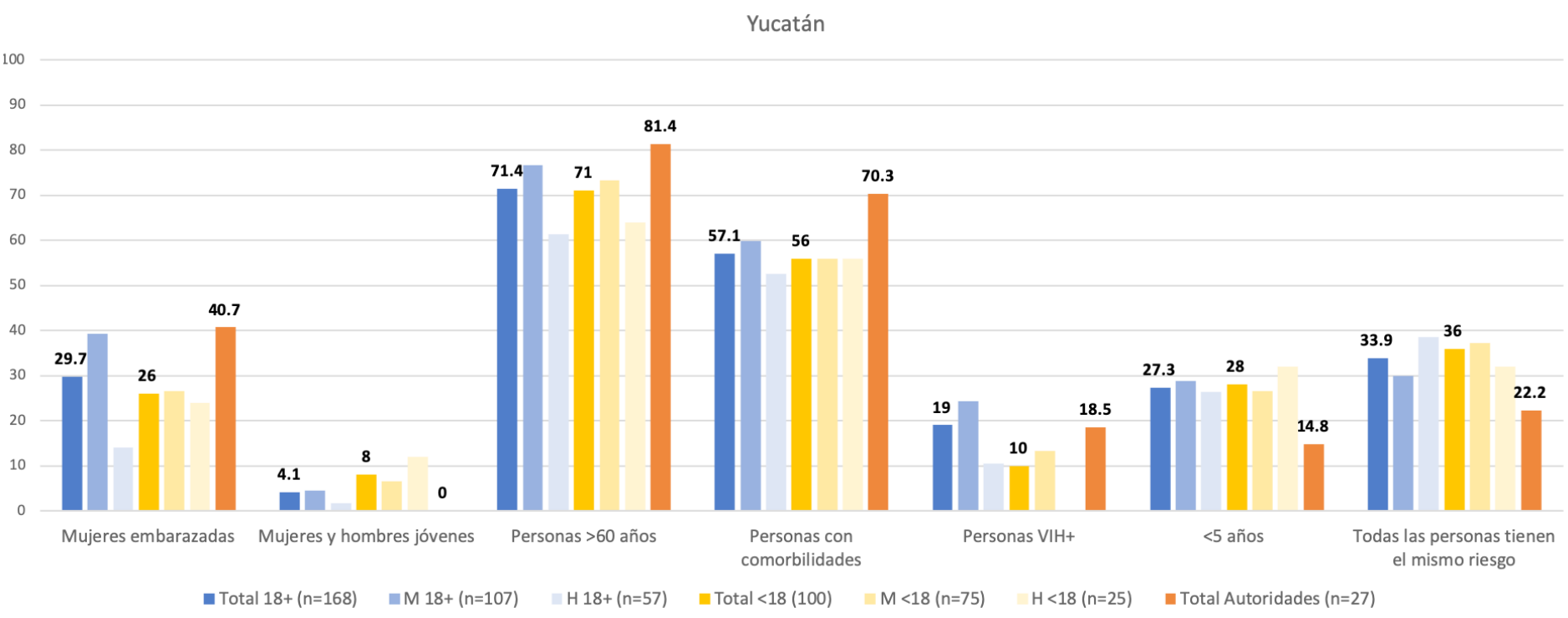

Nota: Los porcentajes no suman $100 \%$ por ser pregunta con respuesta de opción múltiple

Los síntomas que se identifican en mayor porcentaje tanto por población adulta, como por adolescentes y autoridades comunitarias son fiebre $(>75 \%)$, falta de aire $(60-$ $80 \%)$ y dolor de cabeza (50-60\%).
Sin embargo, se observa un menor conocimiento con respecto a síntomas leves de COVID-19, identificados por menos del $30 \%$ de la población encuestada (ver Figura 2).

Figura 2. Porcentaje de población encuestada que identifica síntomas graves y leves asociados con COVID-19, por grupo encuestado y sexo. Yucatán, 2020.

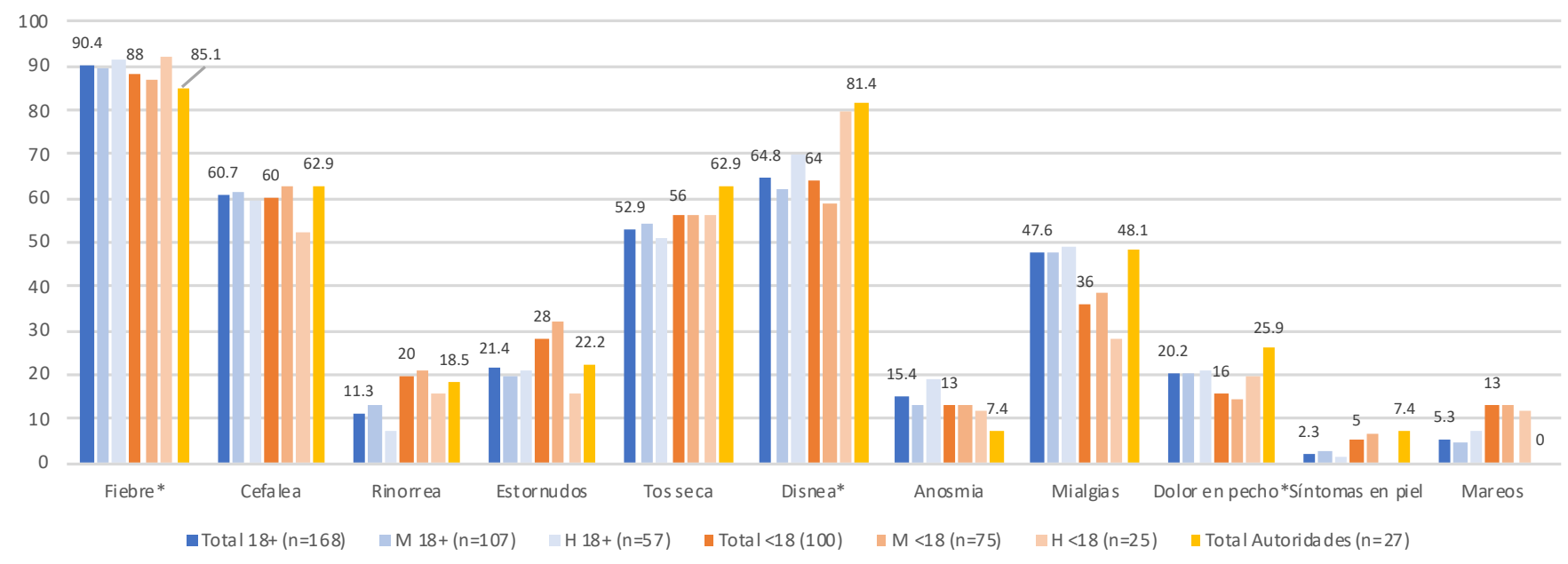

Nota: Los porcentajes no suman $100 \%$ por ser pregunta con respuesta de opción múltiple 
Respecto al conocimiento sobre las medidas de prevención, las tres medidas más conocidas en población adulta y adolescente son: el lavado de manos (80.3\% y $80.0 \%$, respectivamente), el mantenimiento de la sana distancia $(70.2 \%$ y $72.0 \%$, respectivamente), evitar tocarse la cara $(61.3 \%$ y $59.0 \%$, respectivamente) y el uso de cubrebocas $(60.1 \%$ y $54 \%$, respectivamente). Llama la atención el bajo nivel conocimiento respecto de las medidas de sanitización, el estornudo de etiqueta y evitar el contacto con personas enferma de COVID-19 o evitar salir si se está enfermo. En general los hombres tienen un menor nivel de conocimientos sobre algunas medidas de prevención en comparación con las mujeres. En general, las autoridades comunitarias mostraron un grado de conocimiento de medidas de prevención similar al de las personas adultas. Sin embargo, en todos los grupos encuestados se observa la necesidad de reforzar algunas medidas como son: limpieza de superficies, estornudo de etiqueta y evitar el contacto con personas que tienen síntomas de COVID-19 (ver Figura 3).

Figura 3. Porcentaje de población encuestada que identifica distintas medidas de prevención de COVID-19, por grupo encuestado y sexo. Yucatán, 2020.

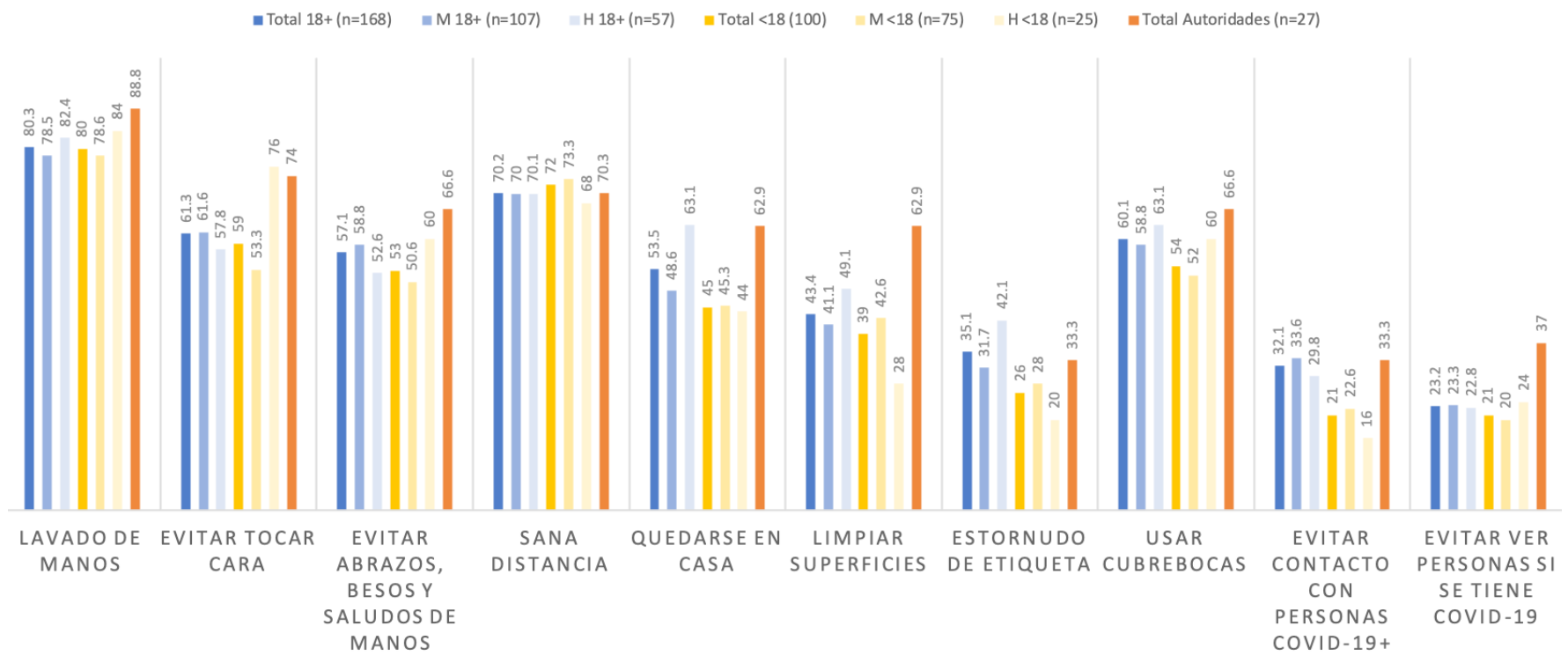

Nota: Los porcentajes no suman $100 \%$ por ser pregunta con respuesta de opción múltiple

Uno de los objetivos de esta encuesta, es identificar si existen creencias basadas en conocimientos incorrectos sobre la prevención de esta enfermedad. Esto es relevante pues en ocasiones los mitos y creencias pueden derivar en una toma de decisiones equivocada o inclusive poner en riesgo su salud. En este sentido, los resultados muestran que hay creencias en la población que los pueden poner en riesgo de infección por Coronavirus por pensar que algunos de estos remedios o acciones los previene de contagio. Los resultados muestran un nivel de aceptación alto en la población sobre estas medidas. Preocupa particularmente, la creencia de rociar el cuerpo con alcohol o cloro para matar el virus en autoridades y personas adultas. Ninguna de las medidas enlistadas en la siguiente tabla son efectivas para evitar el contagio o contrarrestar el virus. La Tabla 3 muestra el porcentaje de personas que consideran como ciertas algunos de los mitos relacionados con la prevención del COVID-19. 
Tabla 3. Porcentaje de personas que consideran como ciertos mitos y creencias relacionados con la prevención y control del COVID-19, por grupo encuestado y sexo. Yucatán, 2020.

\begin{tabular}{|lccc|}
\hline \multicolumn{1}{|c}{ Mito } & $\begin{array}{c}\text { Personas adultas } \\
\mathbf{n}(\%)\end{array}$ & $\begin{array}{c}\text { Adolescentes } \\
\mathbf{n}(\%)\end{array}$ & $\begin{array}{c}\text { Autoridades } \\
\mathbf{n}(\%)\end{array}$ \\
\hline Total de respuestas por grupo encuestado & $\mathbf{n = 1 6 8}$ & $\mathbf{n = 1 0 0}$ & $\mathbf{n = 2 7}$ \\
\hline El ajo puede ayudar a prevenir o curar la infección & $43(26.0)$ & $17(17.0)$ & $4(14.8)$ \\
\hline $\begin{array}{l}\text { Rociar el cuerpo con alcohol o cloro puede matar al } \\
\text { Coronavirus }\end{array}$ & $68(40.4)$ & $28(28.0)$ & $10(37.0)$ \\
\hline $\begin{array}{l}\text { Tomar bebidas calientes o comer caldos calientes mata } \\
\text { al virus }\end{array}$ & $65(39.1)$ & $43(43.0)$ & $11(40.7)$ \\
\hline $\begin{array}{l}\text { Consumir miel melipona ayuda a prevenir la infección por } \\
\text { sus propiedades curativas }\end{array}$ & $74(44.0)$ & $28(28.0)$ & $10(37.0)$ \\
\hline $\begin{array}{l}\text { En climas calientes el virus no se contagia con tanta } \\
\text { facilidad }\end{array}$ & $64(38.3)$ & $45(45.0)$ & $10(37.0)$ \\
\hline $\begin{array}{l}\text { Enjuagarse la nariz con agua con sal y hacer gárgaras } \\
\text { con enjuague bucal, puede prevenir el contagio }\end{array}$ & $49(29.1)$ & $25(25.0)$ & $7(25.9)$ \\
\hline Consumir hielo ayuda a prevenir la infección & $10(5.9)$ & $5(5.0)$ & $1(3.7)$ \\
\hline Nota: Los porcentajes no suman 100\% por ser pregunta con respuesta de opción múltiple. & \\
\hline
\end{tabular}

Por último, se les preguntó a las autoridades comunitarias si alguna instancia gubernamental les había brindado información relacionada con el COVID-19 y el tipo de información brindada. $14.8 \%$ respondió que no habían recibido información sobre COVID-19 por parte de una instancia gubernamental, $59.2 \%$ indicaron que recibieron esta información por parte de la Secretaría de Salud Estatal, $37.0 \%$ por parte del gobierno del estado y $25.9 \%$ por parte de las autoridades municipales.
Las autoridades identificaron que se les brindó información principalmente sobre lavado correcto de manos $(70.3 \%)$, uso de gel antibacterial $(70.3 \%)$ y protocolos de referencia (55.5\%). Menos del 20\% mencionó haber recibido información sobre cuándo una persona que presenta síntomas debe de buscar atención médica, cuándo es necesario referir a una persona con síntomas a los servicios de salud y sobre los mitos y creencias relacionados con el COVID-19 (ver Figura 4).

Figura 4. Tipo de información recibida por las autoridades comunitarias con respecto al COVID-19 por parte de instituciones gubernamentales. Porcentajes. Yucatán, 2020.

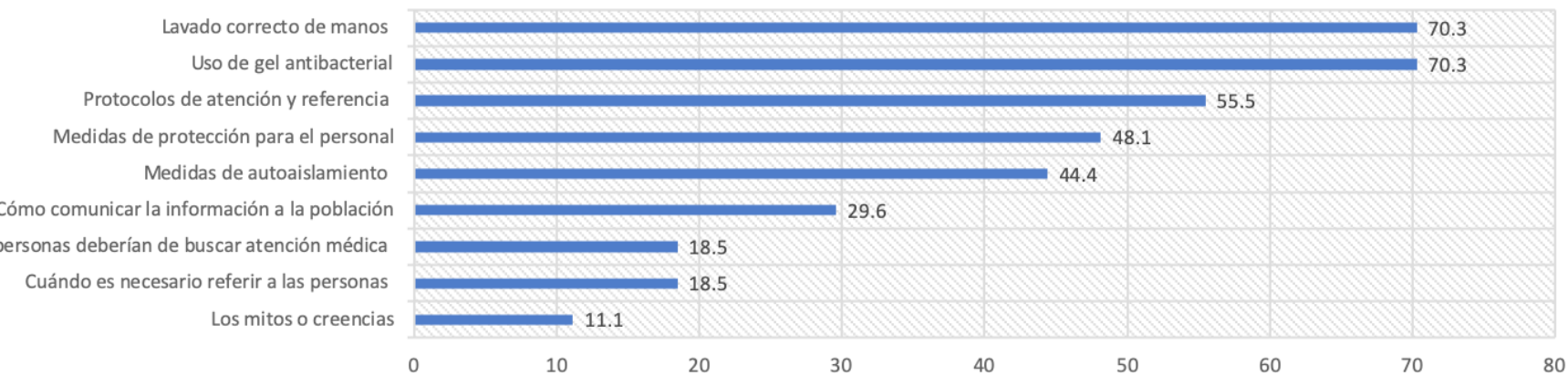

Nota: Los porcentajes no suman 100\% por ser pregunta con respuesta de opción múltiple 
Con respecto al grado de preocupación a que el informante o un familiar suyo se enferme por COVID-19, se observó que $82.7 \%$ de las personas adultas $(85.0 \%$ de las mujeres y $80.7 \%$ de los hombres) y $64.6 \%$ las y los adolescentes en Yucatán identifican sentirse muy preocupados por la pandemia. $81.4 \%$ de las autoridades comunitarias también informaron sentirse muy preocupada. Sin embargo, $40.7 \%$ de este grupo encuestado percibe como bajo el riesgo de que alguien en su comunidad se contagie con el SARS-CoV-2 y menos del $30 \%$ señaló que este riesgo es elevado.

Los principales miedos con relación al COVID-19 fueron identificados mediante pregunta abierta, por lo que a continuación se presentan los resultados expresados por las personas participantes y algunas citas que consideramos importantes y que fueron rescatadas de las respuestas:

» Miedo a contagiarse y a que ellas/os o alguno de sus familiares mueran por el Coronavirus.

" "Miedo por ser una enfermedad letal que puede arrasar con todos los miembros de mi familia”

\section{Participante, 17 años}

» Miedo a no saber quién tiene la enfermedad y a juntarse con personas que puedan tener COVID-19.

» Miedo a que el virus llegue a sus comunidades. Se menciona en varias ocasionas el miedo a que personas de fuera traigan la enfermedad a la comunidad.

» "Miedo a que las personas que salgan de la comunidad traigan de regreso la enfermedad con ellas"

Participante, 28 años

" Miedo a que en la comunidad se sepa que ellas o alguno de sus familiares tenga el COVID-19.
" "La respuesta de la población al saber que alguien en mi familia sufre de esta enfermedad, la exclusión y el rechazo de la sociedad"

\section{Participante, 24 años}

» Miedo a contagiar a alguien de su familia.

» Miedo al impacto económico en la familia si uno de los miembros llegase a enfermar por el virus, asociado al costo de la hospitalización y medicamentos para tratar el COVID-19.

» "Que mi familia se enferme y no contar con dinero para su atención"

\section{Participante, 63 años}

»Preocupación por la saturación de los hospitales y la falta de medicamentos.

» Impacto social y económico de la pandemia en su familia y en su comunidad, incluyendo la pérdida de trabajos y la falta de insumos básicos (sobre todo de alimentos).

La principal preocupación con respecto a la pandemia entre las personas adultas encuestadas es la inseguridad alimentaria, con un mayor porcentaje en hombres $(73.6 \%)$ en comparación con las mujeres (67.2\%). En segundo lugar la menor oportunidad laboral (68.4\% de los hombres y $55.1 \%$ de las mujeres), y en tercer lugar la pérdida del trabajo (42.1\% de los hombres y $28.9 \%$ de las mujeres). Se observa una mayor preocupación sobre el rezago educativo de sus hijos e hijas en las mujeres $(28.0 \%)$ en comparación con los hombres $(17.5 \%)$, así como de la pérdida de apoyos por parte del gobierno (24.3\% de las mujeres y $19.3 \%$ de los hombres) y el no poder vender productos locales $(28.9 \%$ de las mujeres y $19.3 \%$ de los hombres). La pérdida de la casa fue más evidente entre las mujeres, aunque no se encuentra dentro de las preocupaciones principales en este grupo poblacional (ver Figura 5).

Con relación a lo expresado por las autoridades comunitarias, se observa que las principales preocupaciones con respecto al impacto 
Figura 5. Principales preocupaciones expresadas por personas adultas con respecto al impacto del COVID-19 por sexo. Porcentajes. Yucatán, 2020.

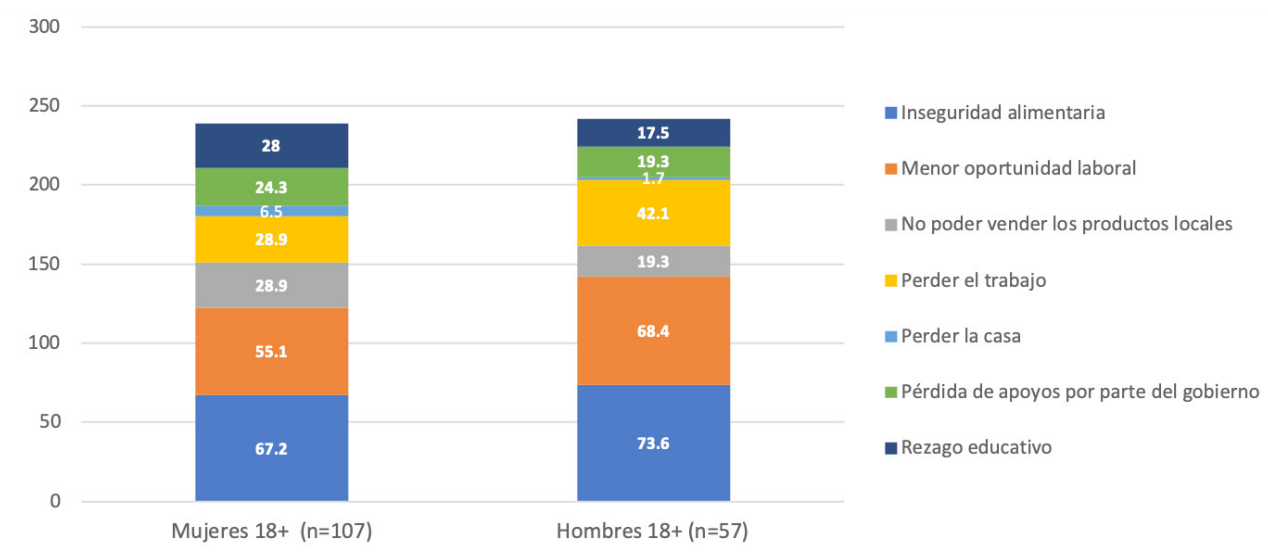

de la pandemia a nivel local son el aumento de violencia en las comunidades (85.1\%), la menor oportunidad laboral $(74.0 \%)$ y el incremento de la pobreza (70.3\%). La princi- pal forma de violencia por la que expresan preocupación las autoridades es la violencia familiar y contra las mujeres (33.3\%) (ver Figura 6).

Figura 6. Principales preocupaciones expresadas por autoridades comunitarias con respecto al impacto del COVID-19 por sexo. Yucatán, 2020.

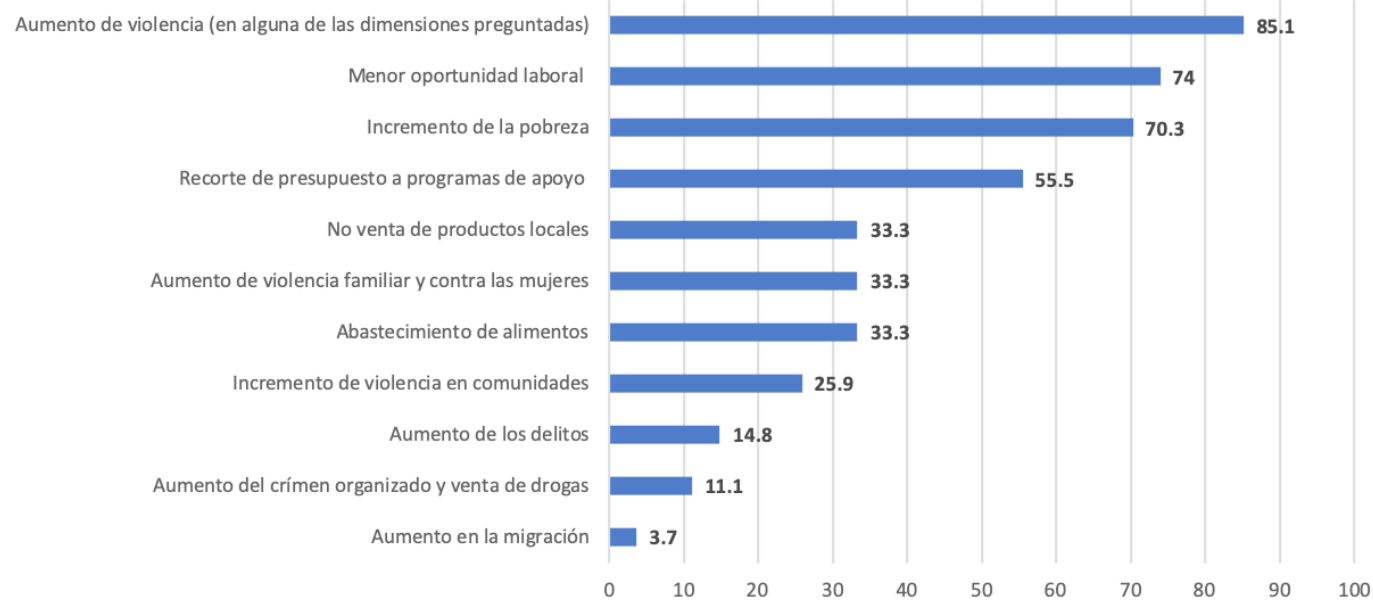

Nota: Los porcentajes no suman 100\% por ser pregunta con respuesta de opción múltiple

Sobre el grado de confianza que se tiene en las medidas implementadas por las autoridades municipales con respecto a la pandemia, la mayoría de las personas adultas contestaron (en una escala del 0 al 10, donde 0 es nada de confianza y 10 es mucha confianza) un puntaje de 5 . Por otro lado, a las autoridades comunitarias se les pidió calificar (con la misma escala) el grado de confianza en las medidas implementadas por las autoridades estatales y federales. Para el primer caso, la mayoría de las autoridades calificaron con 9 su grado de confianza, y para el caso de las autoridades federales con un puntaje de 5 .

Por último, se preguntó sobre los principales sentimientos que han tenido con respecto a la pandemia. En general, se identifica que tanto las mujeres adultas como las adolescentes identifican sentirse más tristes, con más desánimo y con más nervios en comparación con los hombres adultos y los adolescentes, quienes identifican como sentimientos principales la aburrición y tranquilidad (ver Figura 7). 
Figura 7. Principales sentimientos expresados con respecto a la pandemia por grupo encuestado y sexo. Porcentajes. Yucatán, 2020.

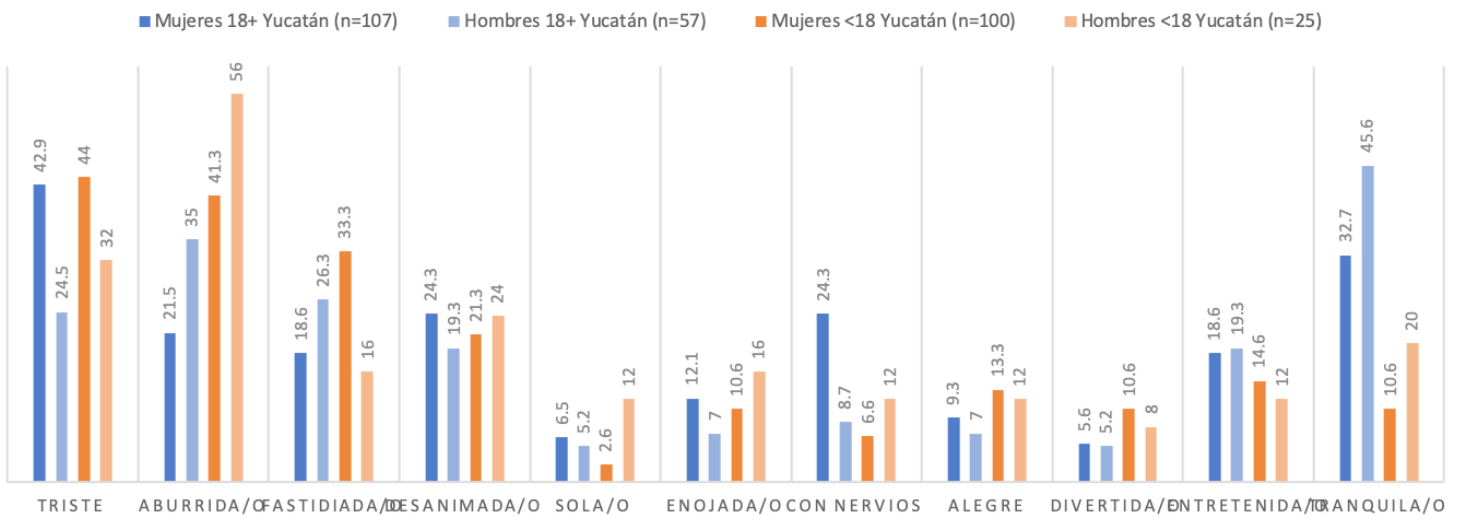

\section{Prácticas}

La Figura 8 muestra las prácticas que las personas adultas, adolecentes y autoridades comunitarias llevarían a cabo si presentaran síntomas de COVID-19. Se observa que la principal prácticas que implementarían sería quedarse en casa y seguir las medidas de prevención recomendadas y, la segunda, sería llamar al número de la "Línea Directa COVID-19" implementada por el gobierno. Sin embargo, menos del $45.0 \%$ de las personas adultas (tanto hombres como mujeres), de las mujeres adolescentes y de las autoridades comunitarias identificaron que usarían cubrebocas, medida que ha demostrado una alta eficacia en reducir la transmisión del virus si, tanto las personas con COVID-19 como las personas sin la enfermedad, lo utilizan. También se preguntó sobre las razones por las cuáles consideran que las personas de su comunidad no quieren o no pueden llevar a cabo las medidas de prevención recomendadas para prevenir la propagación del virus causante del COVID-19. Las tres principales razones mencionadas por las personas adultas y las y los adolescentes fueron la imposibilidad de las personas de quedarse en casa porque tienen que salir a trabajar (82.1\% y $79.0 \%$, respectivamente), el tener que compartir un baño entre varias personas en la casa $(31.5 \%$ y $24.0 \%)$ y vivir en casas que cuentan con una sola habitación $(25.6 \%$ y $19.0 \%)$. Del total de personas adultas y adolescentes encuestadas, $15.0 \%$ identificó que las personas no siguen las medidas porque no consideran que el COVID-19 sea un problema de salud importante en su comunidad. Adicionalmente, $47.0 \%$ de las personas adultas encuestadas identificaron no contar con una habitación para aislarse ellas mismas o a algún familiar en caso de presentar síntomas de COVID-19.

Figura 8. Medidas de prevención de COVID-19 utilizadas más frecuentemente por grupo encuestado y sexo. Porcentajes. Yucatán, 2020.

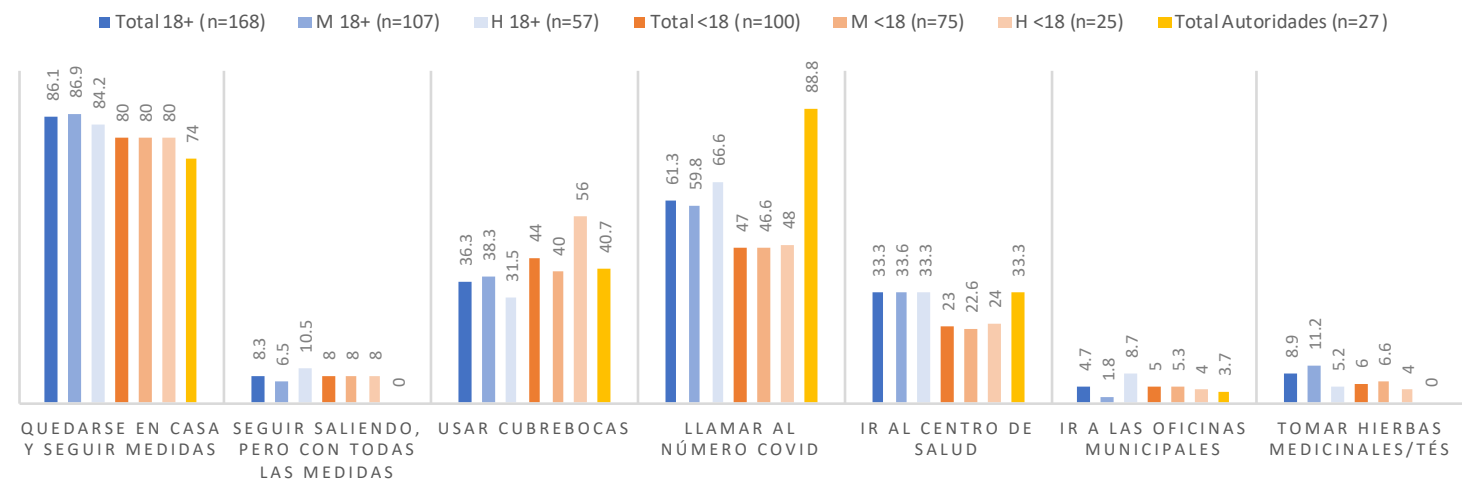

Nota: Los porcentajes no suman 100\% por ser pregunta con respuesta de opción múltiple 
La Tabla 5 describe las medidas de prevención y control de la pandemia implementadas a nivel local que fueron identificadas por las autoridades comunitarias encuestadas.

\begin{tabular}{|c|c|}
\hline Medida de prevención y control a nivel local & $n(\%)$ \\
\hline Toque de queda & $4(14.8)$ \\
\hline $\begin{array}{l}\text { Retén a la entrada de la comunidad para revisar temperatura y } \\
\text { síntomas }\end{array}$ & $24(88.8)$ \\
\hline $\begin{array}{l}\text { Solo se deja entrar a las personas que viven en las comunidades y a } \\
\text { los proveedores de alimentos y otros productos esenciales }\end{array}$ & $18(66.6)$ \\
\hline $\begin{array}{l}\text { Se ha decidido imponer sanciones administrativas (multas) a las } \\
\text { personas que no respeten el quedarse en casa }\end{array}$ & $2(7.4)$ \\
\hline $\begin{array}{l}\text { Se ha decidido imponer sanciones penales (detención por algunas } \\
\text { horas/días) a las personas que no respeten el quedarse en casa }\end{array}$ & $2(7.4)$ \\
\hline $\begin{array}{l}\text { Se exhorta a la población mediante comunicaciones continuas sobre } \\
\text { la importancia de quedarse en casa, pero no se han impuesto sancio- } \\
\text { nes a quiénes no siguen las indicaciones }\end{array}$ & $9(33.3)$ \\
\hline No se ha tomado ninguna medida & $2(7.4)$ \\
\hline
\end{tabular}

Por último, a las autoridades comunitarias se les preguntó en cuáles situaciones referirían a una persona con síntomas a los servicios de salud. La Tabla 6 muestra los resultados de las 22 autoridades comunitarias que respondieron a la pregunta. Llama la atención que la indicación de referir casos a atención médica cuando hay síntomas de gravedad no fue mencionado por todos las autoridades y que algunas mencionaron el antecedente de contacto con casos confirmados de COVID-19 o la referencia de una persona joven sin comorbilidades y con síntomas leves, las cuales no son razones de referencia a los servicios de salud.

Tabla 6. Valoración por autoridades municipales sobre la necesidad de referencia a atención médica a una persona con síntomas de COVID-19 con base en distintos escenarios clínicos. Yucatán, 2020.

\begin{tabular}{|lc|}
\hline Escenario clínico & $\mathrm{n}(\%)$ \\
\hline Una persona joven sin otra comorbilidad que presenta síntomas leves & $9(40.9)$ \\
\hline $\begin{array}{l}\text { Una persona joven sin otra comorbilidad que presenta síntomas } \\
\text { graves }\end{array}$ & $14(63.6)$ \\
\hline $\begin{array}{l}\text { Persona perteneciente a un grupo de riesgo que presenta síntomas } \\
\text { leves }\end{array}$ & $15(68.1)$ \\
\hline $\begin{array}{l}\text { Persona perteneciente a un grupo de riesgo que presenta síntomas } \\
\text { graves }\end{array}$ & $19(79.1)$ \\
\hline $\begin{array}{l}\text { Cualquier persona que haya estado en contacto con alguien que } \\
\text { presentaba síntomas de COVID-19 }\end{array}$ & $23(82.1)$ \\
\hline
\end{tabular}


Figura 9. Porcentaje de personas adultas y adolescentes por medio de comunicación al cual le tienen más confianza para informarse sobre el COVID-19. Yucatán, 2020.

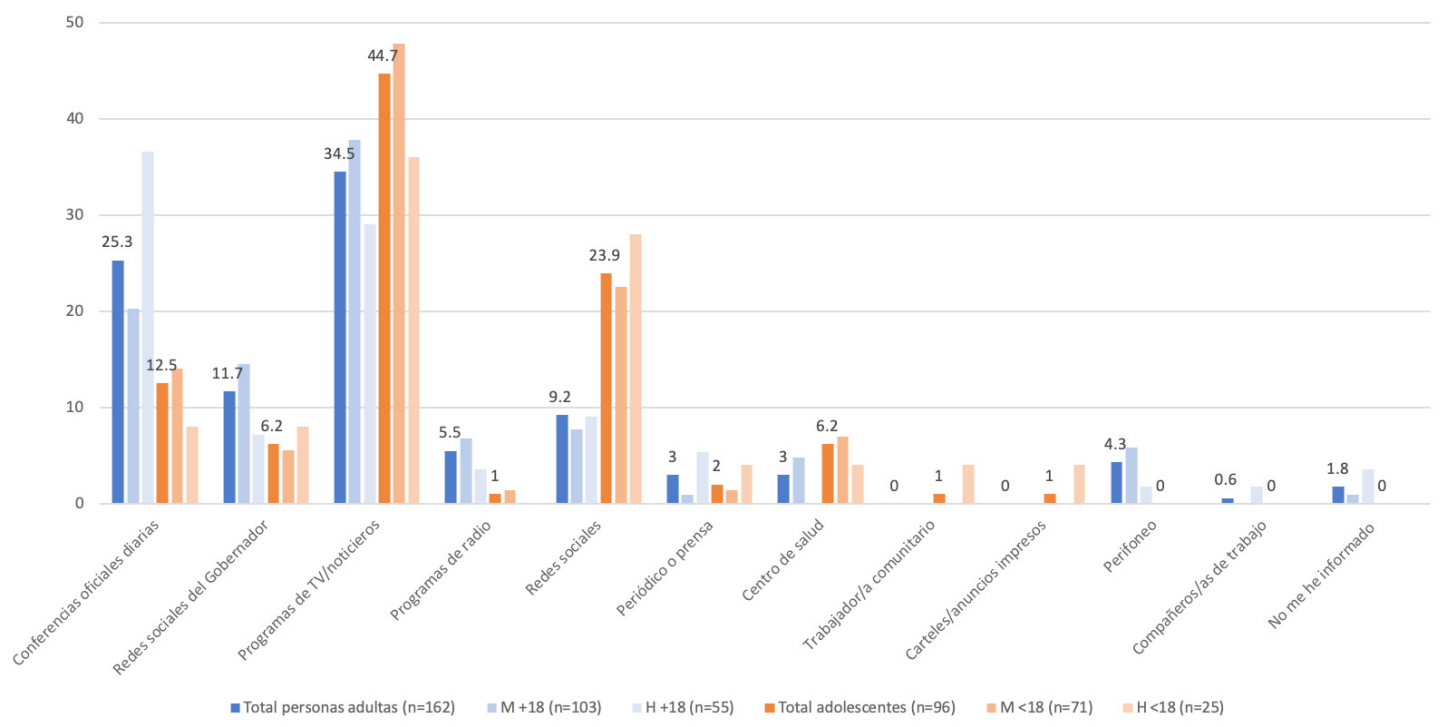

Nota: Los porcentajes no suman $100 \%$ por ser pregunta con respuesta de opción múltiple

\section{Medios de comunicación y diseminación de información relativa a COVID-19}

\section{Confianza en medios de comunicación para informarse sobre COVID-19}

La primera dimensión preguntada con relación a los medios de comunicación fue indicar en cuál medio de comunicación confían más para informarse sobre el COVID-19. Esta pregunta se realizó a población adulta y población adolescente (ver Figura 9).

El principal medio de comunicación al cual le tienen confianza las mujeres adultas son los programas de televisión y noticieros. Los hombres adultos tienen más confianza a las conferencias oficiales diarias del gobierno sobre COVID-19. En el caso de población adolescente, tanto mujeres como hombres tienen más confianza a los programas de televisión y noticieros. Sin embargo, se observa que $23.9 \%$ de las y los adolescentes también confían en las redes sociales (en comparación con $9.2 \%$ de la población adulta). Por último, se observa un bajo nivel de confianza en estrategias como el perifoneo, los carteles $\mathrm{y}$ anuncios impresos, trabajadores/as comunitarios, el centro de salud y el periódico o prensa impresa.

Con respecto a las autoridades, los medios de comunicación que más utilizan para mantenerse informados sobre la pandemia son: conferencias oficiales diarias del gobierno $(81.4 \%)$, redes sociales $(62.9 \%)$, programas de televisión y noticieros $(44.4 \%)$, seguir al Gobernador en redes sociales (40.7\%) y el centro de salud (40.7\%). Utilizan una mediana de tres medios de comunicación para informarse sobre el COVID-19.

Con respecto a las autoridades, los medios de comunicación que más utilizan para mantenerse informados sobre la pandemia son: conferencias oficiales diarias del gobierno $(81.4 \%)$, redes sociales $(62.9 \%)$, programas de televisión y noticieros (44.4\%), seguir al Gobernador en redes sociales $(40.7 \%)$ y el centro de salud (40.7\%). Utilizan una mediana de tres medios de comunicación para informarse sobre el COVID-19.

\section{Idioma de preferencia para recibir información sobre COVID-19}

La segunda dimensión preguntada sobre medios de información, fue la preferencia de idioma para recibir información sobre COVID-19 escrita y en radio, televisión y redes sociales. Esta pregunta también fue 
Figura 10. Porcentaje de personas adultas y autoridades por medio de comunicación de preferencia para informar a la población, sobre todo a población hablante de una lengua indígena, sobre el COVID-19. Yucatán, 2020.

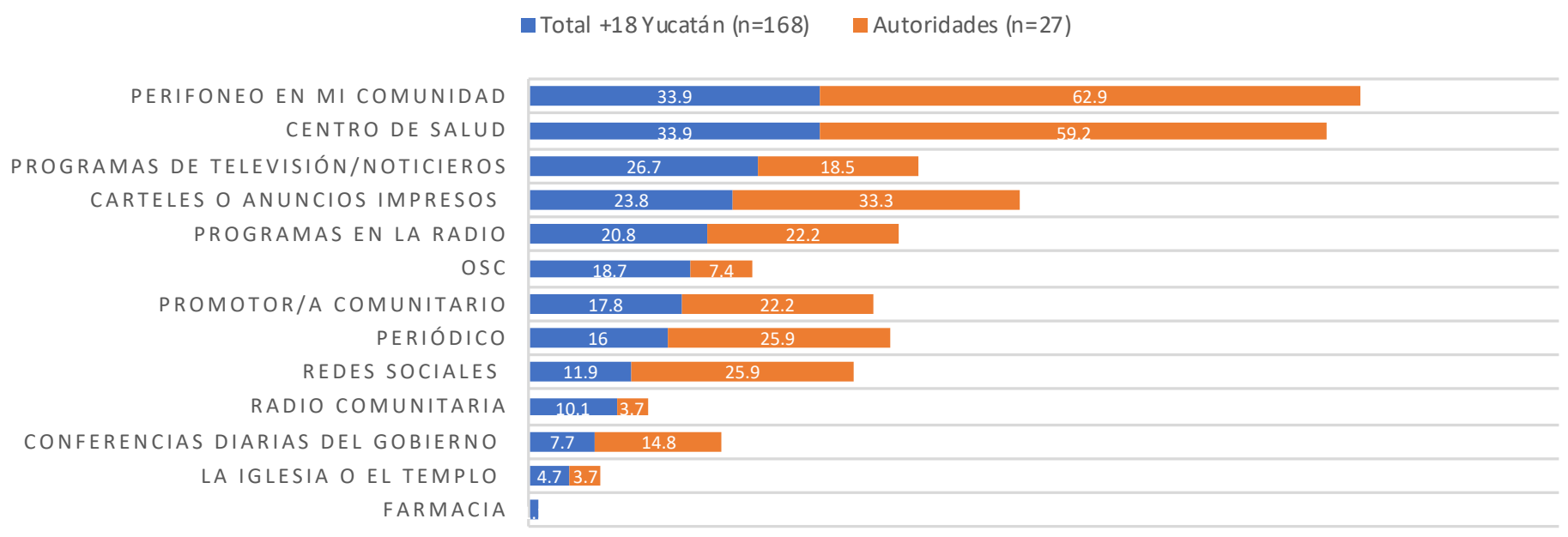

Nota: Los porcentajes no suman $100 \%$ por ser pregunta con respuesta de opción múltiple

realizada a personas adultas y adolescentes. Se identifica una diferencia marcada en la preferencia en los grupos de edad. $34.5 \%$ de la población adulta y $5.0 \%$ de la población adolescente preferiría recibir la información escrita sobre COVID-19 en Maya, mientras que $76.1 \%$ y $95.0 \%$ preferiría recibirla en Español. Para la información recibida por radio, televisión y redes sociales, los porcentajes de preferencia de idioma son parecidos, con $32.7 \%$ de la población adulta y $5.0 \%$ de la población adolescente que preferirían recibir esta información en Maya y 78.3\% y 95.0\% que preferirían recibirla en Español. ${ }^{2}$

\section{Medio de comunicación de preferencia para diseminar la información sobre COVID-19, sobre todo para población hablante de una lengua indígena}

Por último, se preguntó a población adulta y autoridades comunitarias, cuáles creían que eran los medios de comunicación más aptos para diseminar información sobre COVID-19 en población hablante de lengua indígena (ver Figura 10). Se observa que, la población adulta preferiría el uso de perifoneo $(33.9 \%)$, el centro de salud (33.9\%), los programas de televisión y noticieros $(26.7 \%)$ y los carteles y anuncios impresos para informar a la población sobre el COVID-19
(23.8\%).

Las autoridades comunitarias mencionaron como preferencias al perifoneo $(62.9 \%)$, el centro de salud (59.2\%), los carteles o anuncios impresos $(33.3 \%)$ y el periódico y redes sociales $(25.9 \%)$ como los medios para informar a la población sobre el COVID-19.

\section{Impacto de la pandemia en distintas dimensiones de la vida de la población encuestada}

\section{Inseguridad alimentaria}

En Yucatán, 8.9\% de las personas adultas y $17.1 \%$ de las y los adolescentes identificaron no haber desayunado, comido y/o cenado en la última semana debido a que no había suficiente comida para alimentar a toda la familia (ver Figura 11). Los resultados muestran una mayor vulnerabilidad en las mujeres adultas y hombres adolescentes. Se observa que $10.2 \%$ de las mujeres adultas en comparación con $5.2 \%$ de los hombres adultos se encontraron en esta situación, mientras que una mayor proporción de adolescentes hombres $(22.2 \%)$ en comparación con mujeres adolescentes (15.3\%) habían estado en esta situación en la semana previa a la encuesta.

${ }^{2}$ Los porcentajes suman más de $100 \%$, ya que la respuesta era de opción múltiple. 
Figura 11. Porcentaje de personas adultas y adolescentes que no desayunaron, comieron y/o cenaron en la semana previa a la encuesta debido a que no había suficiente comida para toda la familia por sexo. Yucatán, 2020.

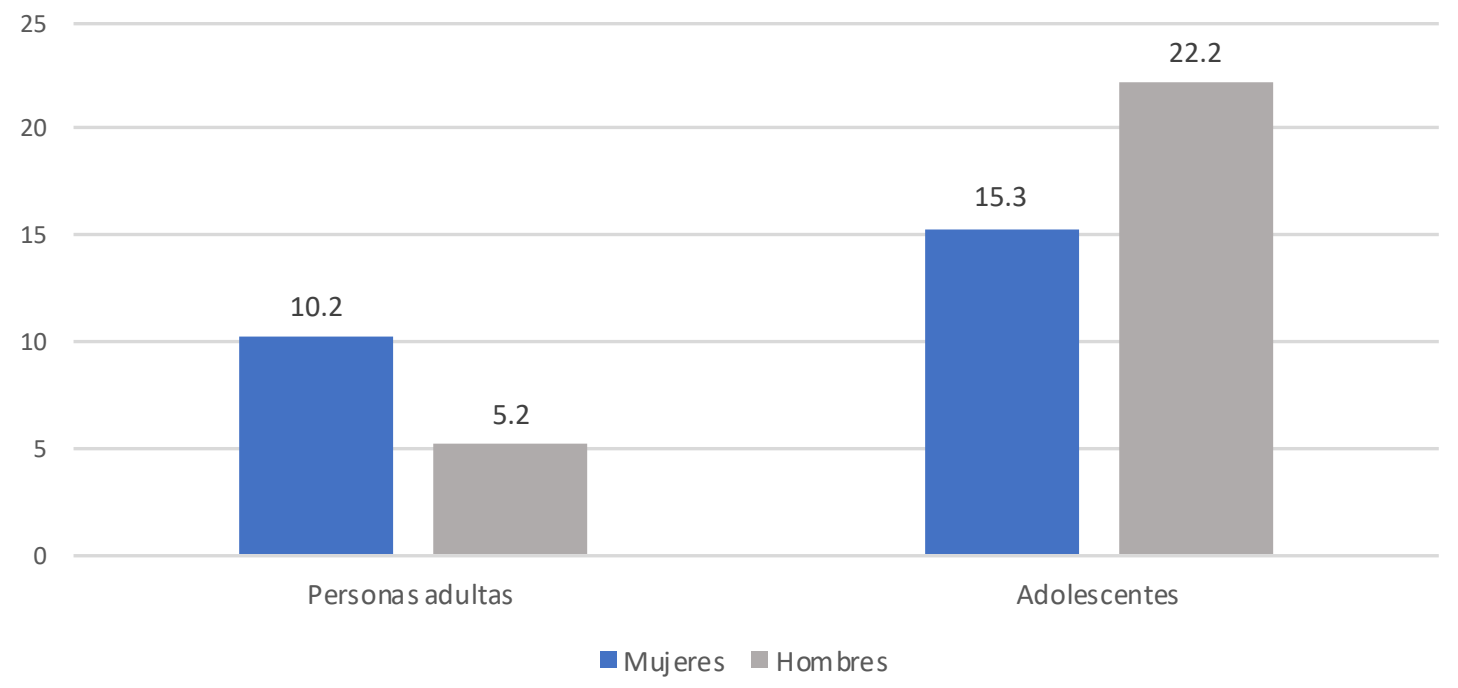

\section{Impacto económico de la pandemia en población adulta encuestada}

Del total de personas adultas encuestadas en Yucatán, $51.4 \%$ de las mujeres y $63.1 \%$ de los hombres habían perdido su trabajo y/o principal fuente de ingreso desde el inicio de la pandemia. Así mismo, 31.4\% de las mujeres adultas y $23.2 \%$ de los hombres adultos identificaron contar con ahorros. De las personas que contaban con ahorros, $35.4 \%$ de las mujeres y $54.5 \%$ de los hombres contestaron que estos ahorros les durarían más de un mes para sostener a su familia, $32.2 \%$ de las mujeres y ninguno de los hombres contestaron que los ahorros durarían entre una semana y un mes y $32.2 \%$ de las mujeres y $45.4 \%$ de los hombres que dichos ahorros durarían menos de una semana. Por otro lado, $32.9 \%$ de las personas adultas encuestadas cuentan con un apoyo por parte del gobierno.

Por otro lado, se preguntaron las actividades económicas realizadas en casa. La principal actividad económica identificada fue el tener animales de patio que pueden consumir $(54.7 \%)$, en segundo lugar se mencionó el hacer milpa (45.8\%), en tercer lugar producir miel de apis o melipona (27.3\%), y en cuarto lugar el cosechar en casa o terreno propio frutas o verduras (26.7\%). $18.4 \%$ de las personas adultas identificaron no realizar ninguna de las actividades económicas mencionadas. Sin embargo, $52.9 \%$ identificó que la milpa, la cosecha de frutas y verduras y los animales de patio no son suficientes para consumo propio.

Por último, se preguntó sobre algunas estrategias familiares implementadas para disminuir el impacto económico de la pandemia. En general, excepto para cuidar de sus ahorros, un mayor porcentaje de mujeres implementan estrategias para disminuir el impacto económico en comparación con los hombres (ver Figura 12).

\section{Otras dimensiones exploradas}

Finalmente, se exploró quiénes son las personas que han realizado los trabajos del hogar y si han sufrido violencia en casa durante el periodo de confinamiento por la pandemia de COVID-19.

- $73.0 \%$ de las personas adultas identificaron que son las mujeres quiénes realizan los trabajos del hogar, y el $27.0 \%$ restante mencionó que todas y todos ayudan en casa para relizar los trabajos del hogar. 
Figura 12. Porcentaje de personas adultas que han implementado una estrategia familiar para disminuir el impacto económico, por estrategia implementada. Yucatán, 2020.

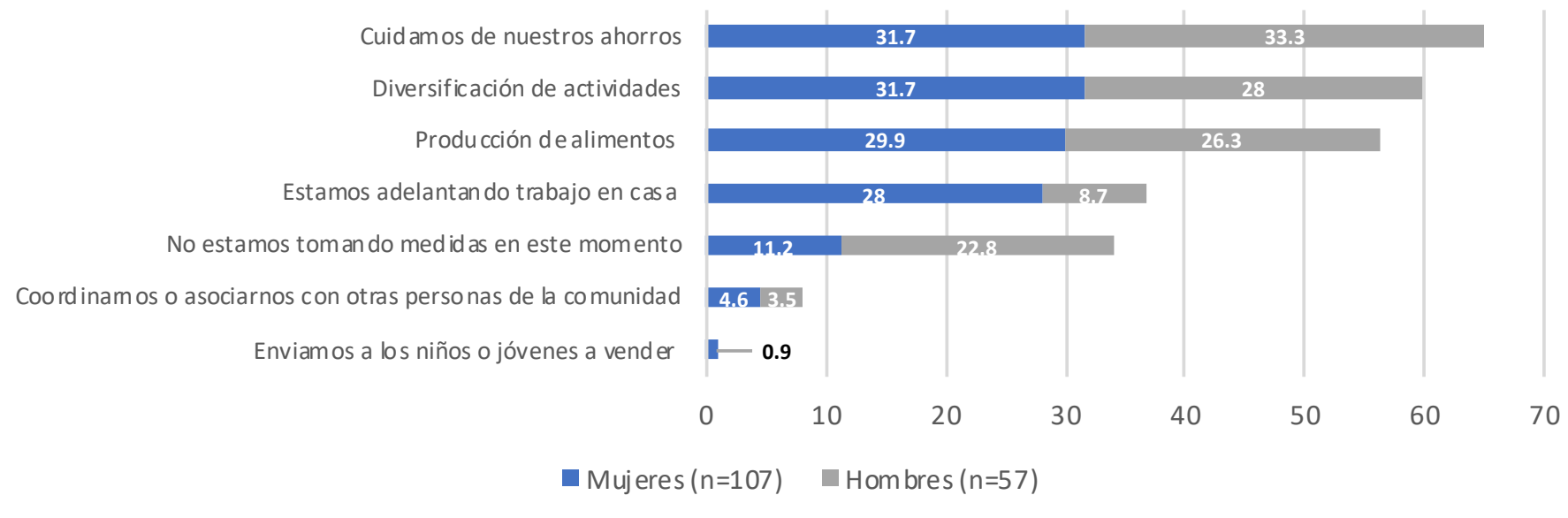

Nota: Los porcentajes no suman $100 \%$ por ser pregunta con respuesta de opción múltiple

- Del total de personas adultas encuestadas, una mujer (de 107 que contestaron la pregunta) y dos hombres (de 57 que contestaron la pregunta), identificaron haber vivido golpes, gritos, empujones y/o malos tratos en casa durante el periodo de confinamiento. En el caso de la población adolescente, cuatro mujeres (de 74 que contestaron la pregunta) y dos hombres (de 25 que contestaron la pregunta), identificaron haber sufrido alguna de estas situaciones.

\section{Educación y COVID-19 en población adolescente encuestada}

Del total de adolescentes encuestados, 75.6\% de las adolescentes y $73.9 \%$ de los adolescentes indicaron que siguieron estudiando en casa durante la pandemia. La estrategia utilizada en mayor porcentaje para continuar con sus estudios fue seguir las indicaciones que mandan las y los docentes por Whatsapp y/o redes sociales. La estrategia menos utilizada $(<5.0 \%)$ fue seguir adelante por su cuenta utilizando los libros de texto.

Sobre cómo se sentían con respecto a la modalidad de estudio en casa, se observa que $43.0 \%$ de las y los adolescentes identifican que dejan mucha tarea, $27.0 \%$ mencionó que les gusta ya que pueden ir a su ritmo,
$25.0 \%$ se siente preocupada/o, $18.0 \%$ se siente presionada/o y $6.0 \%$ identifica que no le ve mucho sentido a seguir estudiando dadas las circunstancias.

Por otro lado, $60.7 \%$ de las mujeres adolescentes que siguen estudiando en casa identificaron contar con apoyo en casa para resolver dudas relacionadas con la escuela, en comparación con $47.0 \%$ del total de hombres adolescentes que siguen estudiando en casa.

Por último, de un total de 75 mujeres adolescentes que contestaron la pregunta, $26.6 \%$ cuenta con acceso a internet en casa, en comparación con $24.0 \%$ del total de 25 hombres adolescentes que contestaron la pregunta. Es decir, aproximadamente $75.0 \%$ del total de población adolescente encuestada no cuenta con acceso a internet en casa.

\section{Experiencias y aprendizajes positivos durante la pandemia en la población adolescente encuestada}

Con respecto a las experiencias positivas, la principal experiencia identificada tanto por mujeres como hombres adolescentes, fue el convivir más con sus padres y madres. Se observa que un mayor porcentaje de hombres identificó esta experiencia en comparación con las mujeres $(68.0 \%$ y $54.6 \%$, respecti- 
Figura 13. Porcentaje de personas adolescentes que refieren haber tenido una experiencia positiva durante la pandemia, por tipo de experiencia y sexo. Yucatán, 2020.

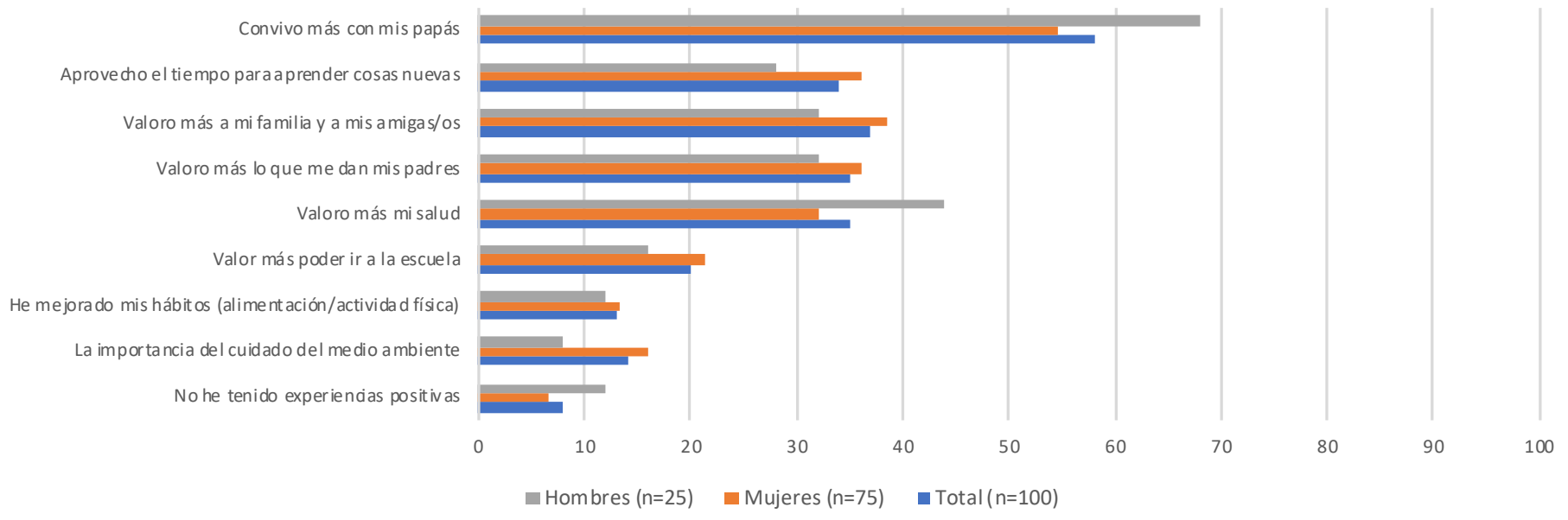

Nota: Los porcentajes no suman $100 \%$ por ser pregunta con respuesta de opción múltiple

vamente). Por otro lado, en general, se puede observar que las mujeres identificaron un mayor número de experiencias positivas en comparación con los hombres. Pero, es de importancia resaltar que un mayor porcentaje de hombres refirieron valorar más su salud desde el inicio de la pandemia en comparación con las mujeres $(44.0 \%$ y $32.0 \%$, respectivamente) (ver Figura 13).
La Figura 14 muestra el porcentaje de adolescentes mujeres y hombres que han aprendido nuevas actividades desde el inicio de la pandemia por COVID-19. Se observa que un mayor porcentaje de mujeres ha aprendido a cocinar y a hacer labores del hogar con respecto a los hombres $(40.0 \%$ vs. $0.0 \%$ y $46.6 \%$ vs. $24.0 \%$, respectivamente) y un mayor porcentaje de hombres han aprendi-

Figura 14. Porcentaje de adolescentes que han aprendido a realizar nuevas actividades durante la pandemia, por tipo de actividad aprendida y sexo. Yucatán, 2020.

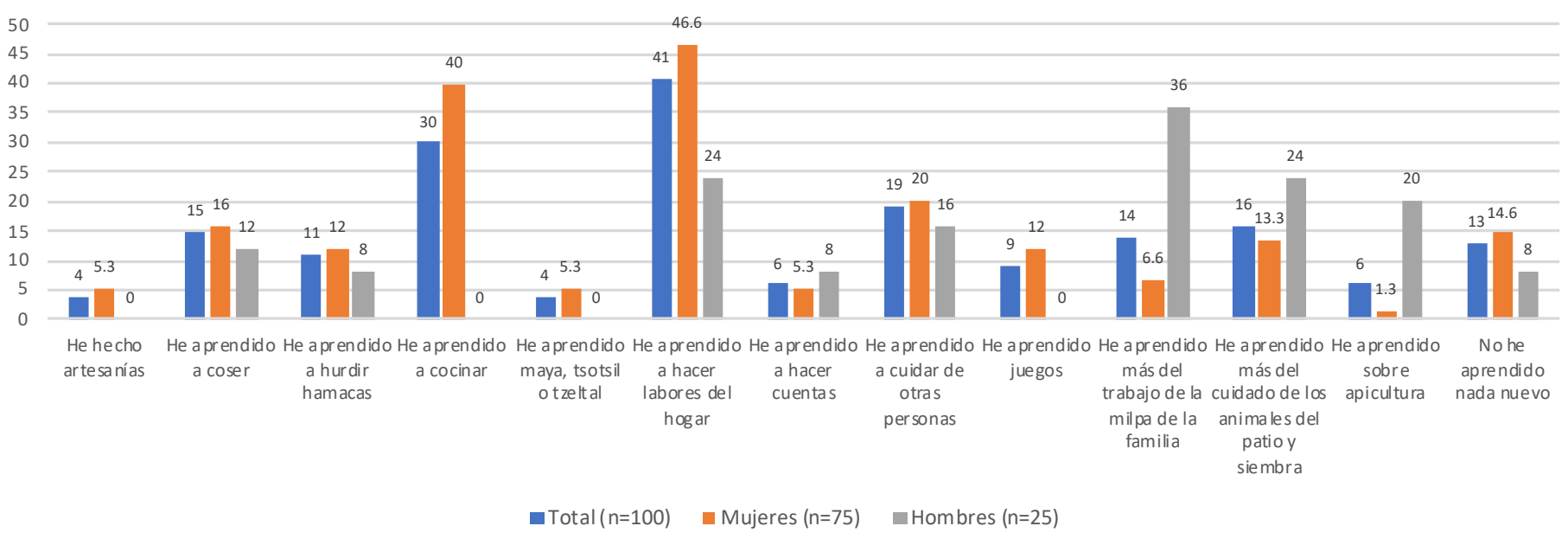

Nota: Los porcentajes no suman $100 \%$ por ser pregunta con respuesta de opción múltiple 


\begin{tabular}{|lcc|}
\hline & $\begin{array}{c}\text { Mujeres }(\mathbf{n}=\mathbf{7 5}) \\
\mathbf{n}(\%)\end{array}$ & $\begin{array}{c}\text { Hombres }(\mathbf{n}=\mathbf{2 5}) \\
\mathbf{n}(\%)\end{array}$ \\
\hline Mamá & $50(66.6)$ & $14(56.0)$ \\
\hline Papá & $5(6.6)$ & $9(36.0)$ \\
\hline Hermana o prima & $24(32.0)$ & $3(12.0)$ \\
\hline Hermano o primo & $5(6.6)$ & 0 \\
\hline Tía & $13(17.3)$ & $6(24)$ \\
\hline Tío & 0 & $3(12)$ \\
\hline Abuela & $10(13.3)$ & $6(24)$ \\
\hline Abuelo & $1(1.3)$ & $3(12.0)$ \\
\hline Amiga/o & $25(33.3)$ & $6(24.0)$ \\
\hline Con nadie & $1(1.3)$ & 0 \\
\hline
\end{tabular}

do más del trabajo de la milpa, del cuidado de los animales de patio y siembre y sobre apicultura que las mujeres $(36.0 \%$ vs. $6.6 \%$, $24.0 \%$ vs. $13.3 \%$ y $20.0 \%$ vs. $1.3 \%$, respectivamente). En estas tendencias podemos observar cómo los roles de género permean las actividades que aprenden las mujeres y hombres adolescentes en casa.

\section{Redes de apoyo durante la pandemia de la población adolescente encuestada}

La última dimensión que fue estudiada en el presente estudio fueron las redes de apoyo con las que cuentan las y los adolescentes durante la pandemia. Se preguntó sobre frecuencia en la que comparten sus sentimientos con respecto a la pandemia, con quién los comparten y grado en el que se sienten escuchadas y escuchados.

Sobre la frecuencia con la que comparten sus sentimientos, se observa que un mayor porcentaje de mujeres adolescentes comparte sus sentimientos casi siempre o simpre (37.3\%) en comparación con hombres adolescentes $(33.3 \%)$ y que un mayor porcentaje de hom- bres adolescentes nunca o casi nunca los comparte con alguien $(33.3 \%)$ en comparación con las mujeres $(26.6 \%)$.

La Tabla 7 muestra las personas con las que más frecuentemente comparten cómo se sienten. En general, tanto mujeres como hombres adolescentes comparten sus sentimientos principalmente con su mamá (66.6\% y 56.0\%, respectivamente). Sin embargo, también es importante hacer notar que, en general, son las figuras femeninas (hermanas, primas, tías, abuelas) con las que se comparte con mayor frecuencia los sentimientos, en comparación con las figuras masculinas.

Finalmente, se preguntó sobre el grado en el que se sienten escuchadas y escuchados cuando comparten sus sentimientos. Se identificó que un mayor porcentaje de hombres adolescentes $(17.3 \%)$ nunca o casi nunca se sienten escuchados, en comparación con $7.9 \%$ de las mujeres adolescentes. Sin embargo, también un mayor porcentaje de hombres se sienten siempre o casi siempre escuchados (60.7\%) en comparación con las mujeres adolescentes $(55.9 \%)$. 


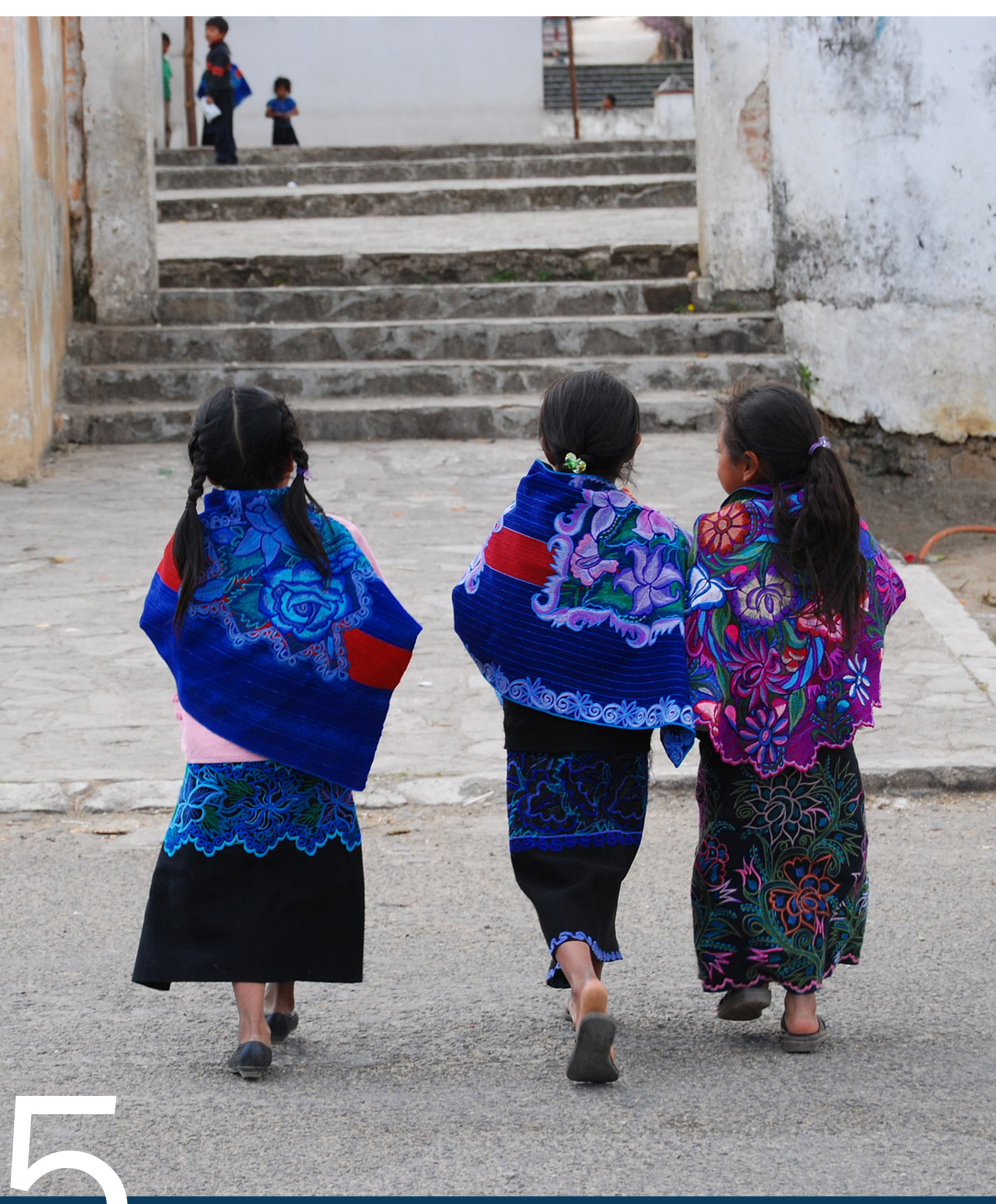




\section{I.Perfil sociodemográfico de las personas encuestadas}

En total, 83 personas fueron encuestadas en Chiapas: 56 personas adultas (18 años y más), 22 adolescentes de entre 14 y 18 ańos y cinco autoridades comunitarias. Las mujeres y hombres adultos eran originarios de 13 municipios, siendo los municipios con mayor participación en este grupo San Cristóbal de las Casas y San Juan Canuc. Las y los adolescentes encuestados eran originarios de seis municipios, siendo Las Margaritas, Tenejapa y Aldama los municipios con mayor participación. Por último, todas las autoridades comunitarias trabajaban en el municipio de Las Margarita (ver Tabla 8 y Mapa 3 y 4 ).

La mediana de la edad de la población adulta encuestada fue de 28 ańos con un rango de 19 ańos a 48 ańos y el promedio de edad de la población adolescente fue de 16.3 ańos (DE \pm 0.7 ańos). Para la población adulta, $71.4 \%$ de la población fue mujer y $28.5 \%$ fue hombre y para las y los adolescentes encuestados $59.1 \%$ fue mujer y $40.9 \%$ fue hombre. $90.0 \%$ de las mujeres adultas y $81.2 \%$ de los hombres adultos identificaron hablar una lengua indígena en comparación con $84.6 \%$ de las mujeres adolescentes y $88.8 \%$ de los hombres adolescentes.

\begin{tabular}{|lccc|}
\hline $\begin{array}{l}\text { Tabla 8. Encuestas realizadas en Chiapas por municipio y grupo } \\
\text { encuestado. Junio, 2020. }\end{array}$ & $\begin{array}{c}\text { Personas } \\
\text { adultas } \\
\mathbf{n}(\%)\end{array}$ & $\begin{array}{c}\text { Adolescentes } \\
\mathbf{n}(\%)\end{array}$ & $\begin{array}{c}\text { Autoridades } \\
\text { comunitarias } \\
\mathbf{n}(\%)\end{array}$ \\
\hline Aldama & $2(3.6)$ & $3(13.6)$ & 0 \\
\hline $\begin{array}{l}\text { Amatenango del } \\
\text { Valle }\end{array}$ & $1(1.8)$ & 0 & 0 \\
\hline Chenalhó & $5(9.0)$ & 0 & 0 \\
\hline Chilón & $5(9.0)$ & 0 & 0 \\
\hline Huixtán & $1(1.8)$ & 0 & 0 \\
\hline Las Margaritas & $6(10.9)$ & $5(22.7)$ & $5(100.0)$ \\
\hline Ocosingo & $1(1.8)$ & 0 & 0 \\
\hline Oxchuc & $1(1.8)$ & 0 & 0 \\
\hline $\begin{array}{l}\text { San Andrés La- } \\
\text { rráinzar }\end{array}$ & $1(1.8)$ & $1(4.5)$ & 0 \\
\hline $\begin{array}{l}\text { San Cristóbal de } \\
\text { las Casas }\end{array}$ & $12(21.8)$ & 0 & 0 \\
\hline San Juan Canuc & $9(16.3)$ & $1(4.5)$ & 0 \\
\hline Santiago el Pinar & 0 & $6(27.2)$ & 0 \\
\hline Sitalá & $6(10.9)$ & $0(27.2)$ & 0 \\
\hline Tenejapa & $4(7.2)$ & 0 & 0 \\
\hline Zinacantán & $1(1.8)$ & 55 & 0 \\
\hline Total & & 0 & 0 \\
\hline
\end{tabular}

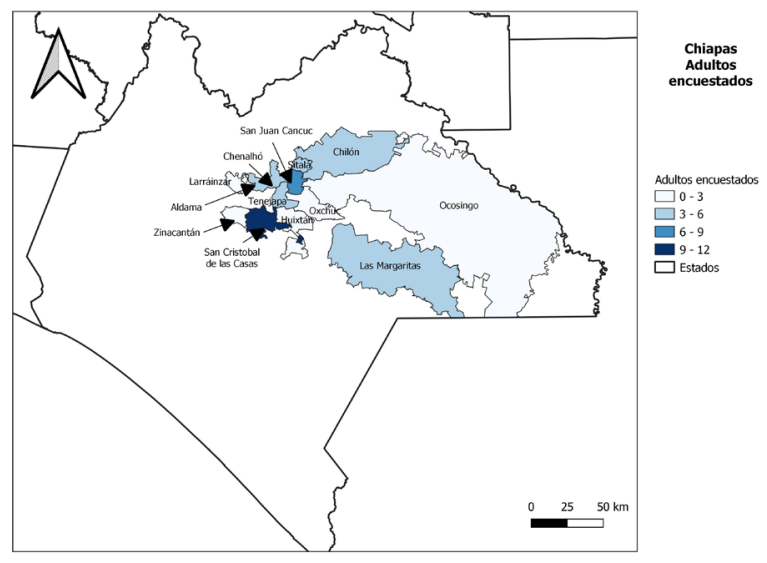

Mapa 3. Municipios participantes. Encuesta a personas adultas, Chiapas. 2020.

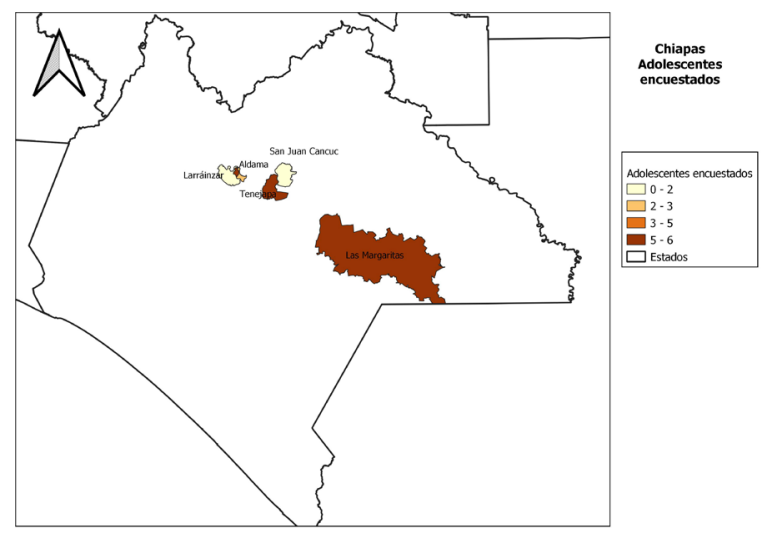

Mapa 4. Municipios participantes. Encuesta a adolescentes, Chiapas. 2020. 


\begin{tabular}{|c|c|c|c|c|}
\hline & $\begin{array}{l}\text { Mujeres adultas } \\
\quad(n=40)\end{array}$ & $\begin{array}{l}\text { Hombres adultos } \\
\qquad(n=16)\end{array}$ & $\begin{array}{c}\text { Mujeres adolescentes } \\
\qquad(n=13)\end{array}$ & $\begin{array}{l}\text { Hombres adolescentes } \\
\qquad(n=9)\end{array}$ \\
\hline Edad* & $28(19-48)$ & $29(22-45)$ & $16.1(0.6)$ & $16.3(0.7)$ \\
\hline Sexo** & $40(71.4)$ & $16(28.6)$ & $13(59.1)$ & $9(40.9)$ \\
\hline $\begin{array}{l}\text { Hablantes de lengua } \\
\text { indígena** }\end{array}$ & $36(90.0)$ & $13(81.2)$ & $11(84.6)$ & $8(88.8)$ \\
\hline Años de escolaridad $* * *$ & $8.0(2.9)$ & $9.8(0.3)$ & $9.3(0.4)$ & $9(1.5)$ \\
\hline $\begin{array}{l}\text { Número de habitantes } \\
\text { por hogar } * * *\end{array}$ & $8.2(1-18)$ & $4.7(2-8)$ & No aplica & No aplica \\
\hline \multicolumn{5}{|c|}{$\begin{array}{l}\text { * La edad se presenta como mediana con mínimos y máximos para población adulta y como promedio y desviación estándar para adolescentes. } \\
\text { ** Número absoluto y, entre paréntesis, el porcentaje que representa del total. } \\
* * * \text { Los años de escolaridad están representados como el promedio y la desviación estándar. } \\
\text { **** El número de habitantes por hogar se presenta como la mediana con los mínimos y máximos entre paréntesis. }\end{array}$} \\
\hline
\end{tabular}

\section{Conocimientos, actitudes y prácticas relacionadas a la pandemia por COVID-19}

\section{A. Conocimientos}

Las encuestas muestran que la mayoría de la población entrevistada identifica correctamente a los principales grupos en riesgo de tener complicaciones graves y muerte por COVID-19 (ver Figura 15):

- Los adultos mayores; $y$,

- Las personas que tienen otras enfermedades crónicas

Sin embargo, se identifican en menor por- centaje a los menores de cinco ańos $(<20 \%$ entre población adulta y $<41 \%$ entre adolescentes) y las mujeres embarazadas $(<45 \%$ en todos los grupos encuestados). Algunos estudio realizados en otros países han identificado un aumento en la incidencia de síndromes sistémicos (tipo Kawasaki) en niñas y niños, y un aumento en la mortalidad materna asociada a COVID-19, por lo que se están considerando para este análisis como grupos de riesgo. Por otro lado, las personas que viven con VIH y que presentan un sistema inmune deprimido (conteo bajo de células TCD4+) y/o comorbilidades, también se han identificado como un posible grupo que pudiera estar en riesgo de presentar complicaciones graves o muerte por COVID-19.

Figura 15. Porcentaje de población encuestada que identifica a los grupos en riesgo de complicaciones graves y/o muerte por COVID-19, por grupo encuestado y sexo. Chiapas, 2020.

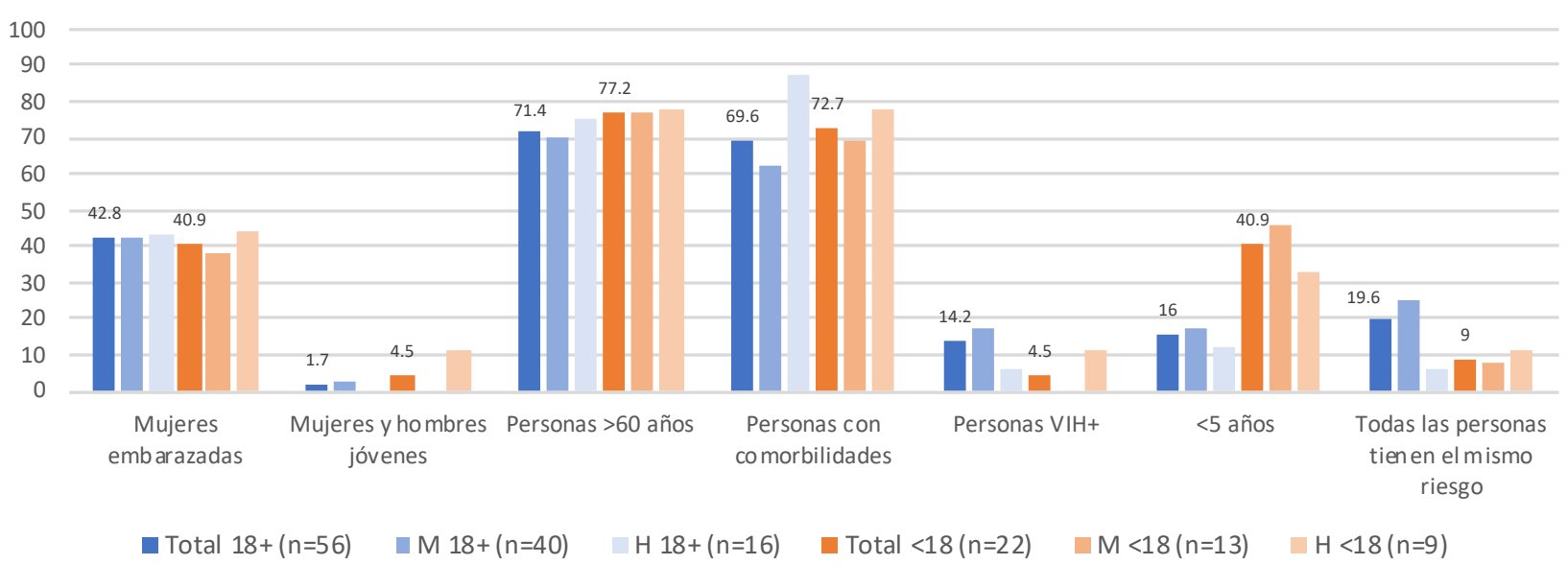

Nota: Los porcentajes no suman $100 \%$ por ser pregunta con respuesta de opción múltiple 


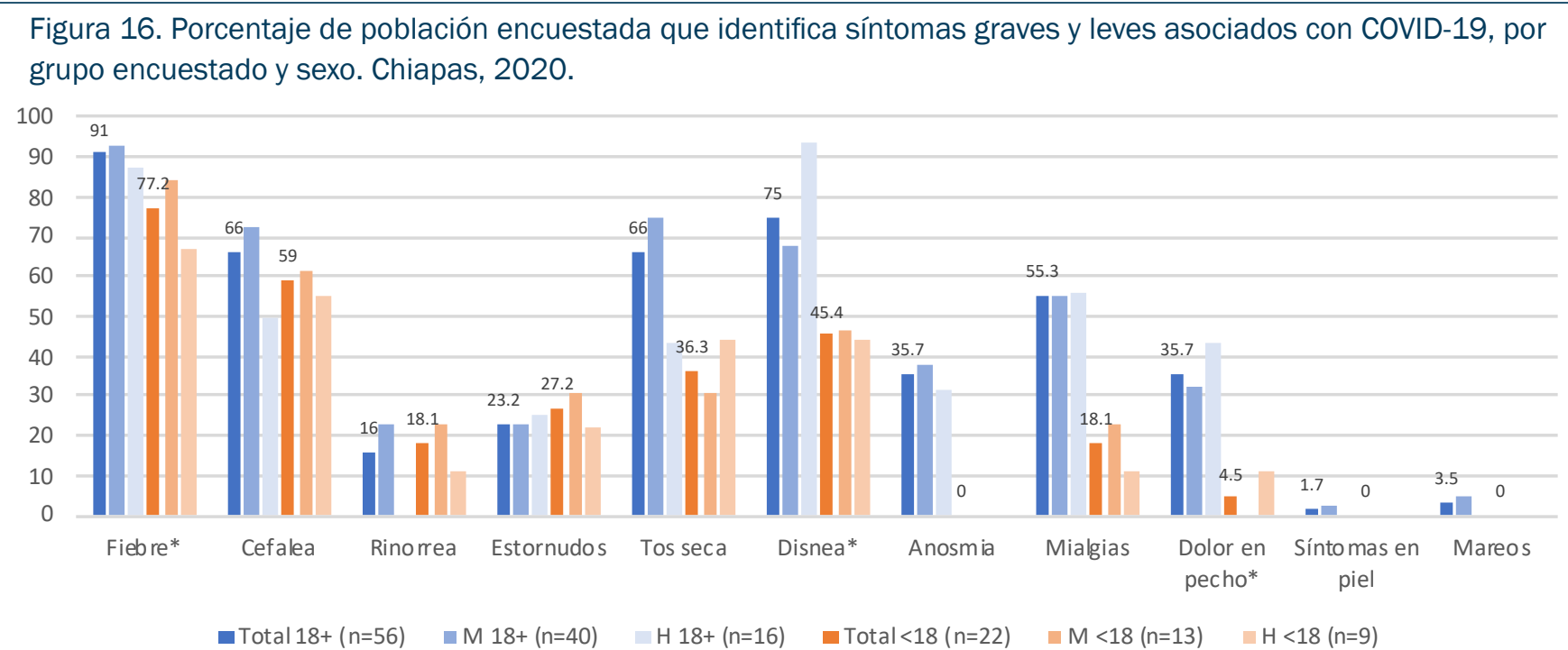

Nota: Los porcentajes no suman $100 \%$ por ser pregunta con respuesta de opción múltiple

Sobre las autoridades comunitarias, 4/5 autoridades identificaron a las personas mayores de 60 años, $3 / 5$ a personas con otras enfermedades, $1 / 5$ a las mujeres embarazadas, $0 / 5$ a las personas que viven con VIH y $2 / 5$ a las niñas y niños menores de 5 años como grupos de riesgo para complicaciones graves y/o muerte por COVID-19.

Los síntomas del COVID-19 que fueron identificados en mayor porcentaje por las personas que participaron en la encuesta fueron los que la Secretaría de Salud y otras instituciones han recalcado mediante sus comunicados: fiebre, tos seca, dolor de cabeza, dificultad para respirar y dolor muscular (mialgias). Sin embargo, otros síntomas que indican que puede estar presente la enfermedad (mocos o fluido nasal, estornudos, pérdida del olfato, mareos y erupción o sarpullido de la piel) fueron identificados por un menor porcentaje de la población (menos del $40 \%)$.

Por otro lado, en la mayoría de los síntomas preguntados, se identifica un mayor desconocimiento entre hombres que mujeres (excepto para disnea) y mayor desconocimiento entre población adolescente en comparación con población adulta (ver Figura 16).

Con respecto a la identificación de los síntomas de gravedad por parte de las autoridades comunitarias, se observó que 3/5 identificaron a la fiebre, disnea y dolor en el pecho como síntomas relacionados con el COVID-19. Sobre síntomas leves pero comunes del COVID-19, 3/5 autoridades, $1 / 5$ y $2 / 5$ identificaron al dolor de cabeza, la tos seca y la pérdida del gusto y la pérdida del sentido del olfato.

Respecto al conocimiento sobre las medidas de prevención, las tres medidas más conocidas en población adulta son: el lavado de manos $(87.5 \%)$, el mantenimiento de la sana distancia $(75.0 \%)$, evitar tocarse la cara y evitar abrazar, besar y saludar de mano (73.2\%). Entre población adolescente se observa un mayor conocimiento del lavado de manos $(90.9 \%)$, quedarse en casa $(50.0 \%)$ y evitar tocarse la cara y evitar abrazar, besar y saludar de mano (45.4\%). En general la población adolescente y las mujeres adultas mostraron un menor nivel de conocimientos sobre las medidas preventivas. En todos los grupos encuestados se observa la necesidad de reforzar algunas medidas como son: uso de cubrebocas, limpieza de superficies, estornudo de etiqueta y evitar el contacto con personas que tienen síntomas de COVID-19 (ver Figura 17).

De las autoridades comunitarias, las cinco autoridades encuestadas identificaron la mayoría de las medidas de prevención para evitar contagios de COVID-19, a excepción de evitar el contacto con personas que tienen síntomas de COVID-19. 
Figura 17. Porcentaje de población encuestada que identifica distintas medidas de prevención de COVID-19, por grupo encuestado y sexo. Chiapas, 2020.

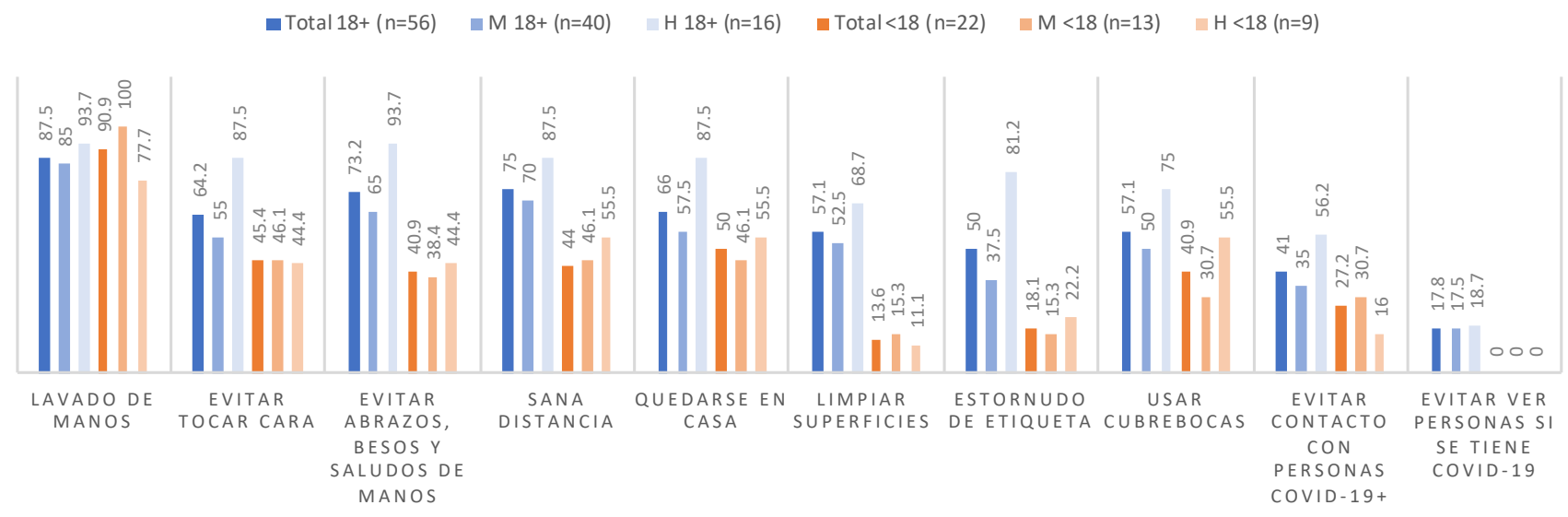

Nota: Los porcentajes no suman $100 \%$ por ser pregunta con respuesta de opción múltiple

Por otro lado, uno de los objetivos de esta encuesta, es identificar si existen creencias basadas en conocimientos incorrectos sobre la prevención de esta enfermedad. Esto es relevante pues en ocasiones los mitos y creencias pueden derivar en una toma de decisiones equivocada o inclusive poner en riesgo su salud. En este sentido, los resultados muestran que hay creencias en la población que los pueden poner en riesgo de infección por Coronavirus por pensar que algunos de estos remedios o acciones los previene de contagio. Ninguna de las medidas enlistadas en la siguiente tabla, son efectivas para evitar el contagio o contrarrestar el virus. La Tabla 10 muestra el porcentaje de personas que consideran como ciertas algunos de los mitos relacionados con la prevención del COVID-19.

Por último, se les preguntó a las autoridades comunitarias si alguna instancia gubernamental les habían brindado información relacionada con el COVID-19 y el tipo de información brindada. Cuatro de las cinco autoridades encuestadas indicaron que recibieron esta información por parte de la Secretaría de Salud Estatal, una autoridad por parte del gobierno del estado y una autoridad por parte de las autoridades municipales. Las autoridades identificaron que se les brindó sobre lavado correcto de manos (4/5 autoridades), uso de gel antibacterial (2/5 autoridades), medidas de protección personal (2/5 autoridades), medidas de autoaislamiento $(5 / 5)$, protocolos de referencia $(5 / 5)$, cuándo una persona que presenta síntomas debe de buscar atención médica (3/5) y cuándo se debe referir a una persona que presenta síntomas a los servicios de salud (1/5). Ninguna autoridad encuestada identificó que se les haya informado sobre los mitos y creencias con respecto al COVID-19.

\section{B. Actitudes}

Con respecto al grado de preocupación a que el informante o un familiar suyo se enferme por COVID-19, los resultados muestran que $53.7 \%$ de las personas adultas $(55.0 \%$ de las mujeres y $50.0 \%$ de los hombres) y $9.0 \%$ las y los adolescentes $(7.6 \%$ de las mujeres y $11.1 \%$ de los hombres) identifican sentirse muy preocupados por la pandemia. Cuatro de las cinco autoridades comunitarias también informaron sentirse muy preocupadas. Sin embargo, ninguna autoridad comunitaria señaló que el riesgo de que alguien en su comunidad se contagie con el SARS-CoV-2 es elevado.

Los principales miedos con relación al COVID-19 fueron identificados mediante pregunta abierta. Es importante señalar que para el caso de Chiapas, ninguna persona adulta o adolescente identificó a la discriminación o el estigma que pudiera existir hacia per- 
Tabla 10. Porcentaje de personas que consideran como ciertos mitos y creencias relacionados con la prevención y control del COVID-19, por grupo encuestado y sexo. Chiapas, 2020.

\begin{tabular}{|lccc|}
\hline Mito & $\begin{array}{c}\text { Personas adultas } \\
\mathbf{n}(\%)\end{array}$ & $\begin{array}{c}\text { Adolescentes } \\
\mathbf{n}(\%)\end{array}$ & $\begin{array}{c}\text { Autoridades } \\
\mathbf{n} / \mathbf{N}\end{array}$ \\
\hline Total de respuestas por grupo encuestado & $\mathrm{n}=56$ & $\mathrm{n}=22$ & $\mathrm{n}=5$ \\
\hline El ajo puede ayudar a prevenir o curar la infección & $18(32.1)$ & $8(36.3)$ & $0 / 5$ \\
\hline Rociar el cuerpo con alcohol o cloro puede matar al Coronavirus & $25(44.4)$ & $6(27.7)$ & $0 / 5$ \\
\hline Tomar bebidas calientes o comer caldos calientes mata al virus & $15(26.7)$ & $13(5.0)$ & $0 / 5$ \\
\hline $\begin{array}{l}\text { Consumir miel melipona ayuda a prevenir la infección por sus } \\
\text { propiedades curativas }\end{array}$ & $13(23.6)$ & $11(5.0)$ & $0 / 5$ \\
\hline En climas calientes el virus no se contagia con tanta facilidad & $16(29.0)$ & $8(36.3)$ & $0 / 5$ \\
\hline $\begin{array}{l}\text { Enjuagarse la nariz con agua con sal y hacer gárgaras con } \\
\text { enjuague bucal, puede prevenir el contagio }\end{array}$ & $12(21.4)$ & $4(18.1)$ & $0 / 5$ \\
\hline Consumir hielo ayuda a prevenir la infección & 0 & 0 & $0 / 5$ \\
\hline Nota: Los porcentajes no suman 100\% por ser pregunta con respuesta de opción múltiple. & & \\
\hline
\end{tabular}

sonas de su misma comunidad que tuvieran COVID-19. A continuación se presentan los resultados expresados por las personas participantes y algunas citas que consideramos importantes y que fueron rescatadas de las respuestas.

- Miedo a contagiarse y a que ellas/os o alguno de sus familiares mueran por el Coronavirus.

- Miedo a contagiar a alguien de su familia.

- Miedo a que el virus llegue a sus comunidades. Se menciona en varias ocasionas el miedo a que personas de fuera traigan la enfermedad a la comunidad.

- "Tengo miedo de que mi familia se contagie de coronavirus, y que las personas que regresaron de trabajar de los Estados Unidos y los que estaban en México y en otros estados vengan con el Virus y contagien a la comunidad"

\section{Participante, 26 años}

- Miedo al impacto económico en la familia si uno de los miembros llegase a enfermar por el virus, asociado al costo de la hospitalización y medicamentos para tratar el COVID-19.
- "Me daría miedo enfermar yo o alguien de mi familia y no poder conseguir los medicamentos, por los gastos que se llegaran a tener, ya que mi familia no cuenta con suficiente dinero"

\section{Participante, 27 años}

- Preocupación por la saturación de los hospitales y la falta de medicamentos.

- Preocupación por que la pandemia no termine.

- No poder regresar a la escuela.

- Impacto social y económico de la pandemia en su familia y en su comunidad, incluyendo la pérdida de trabajos y la falta de insumos básicos (sobre todo de alimentos).

- "Tengo miedo a que pronto nos quedemos sin nuestros ingresos económicos. Mi esposo ha dejado de trabajar desde que inició la pandemia y yo solo cuento con los ingresos de mi actividad productiva (pequeña tienda)"

\section{Participante, 32 años}

La principal preocupación con respecto a la pandemia entre las personas adultas encuestadas es la inseguridad alimentaria, con un 
Figura 18. Principales preocupaciones expresadas por personas adultas con respecto al impacto del COVID-19 por sexo. Porcentajes. Chiapas, 2020.

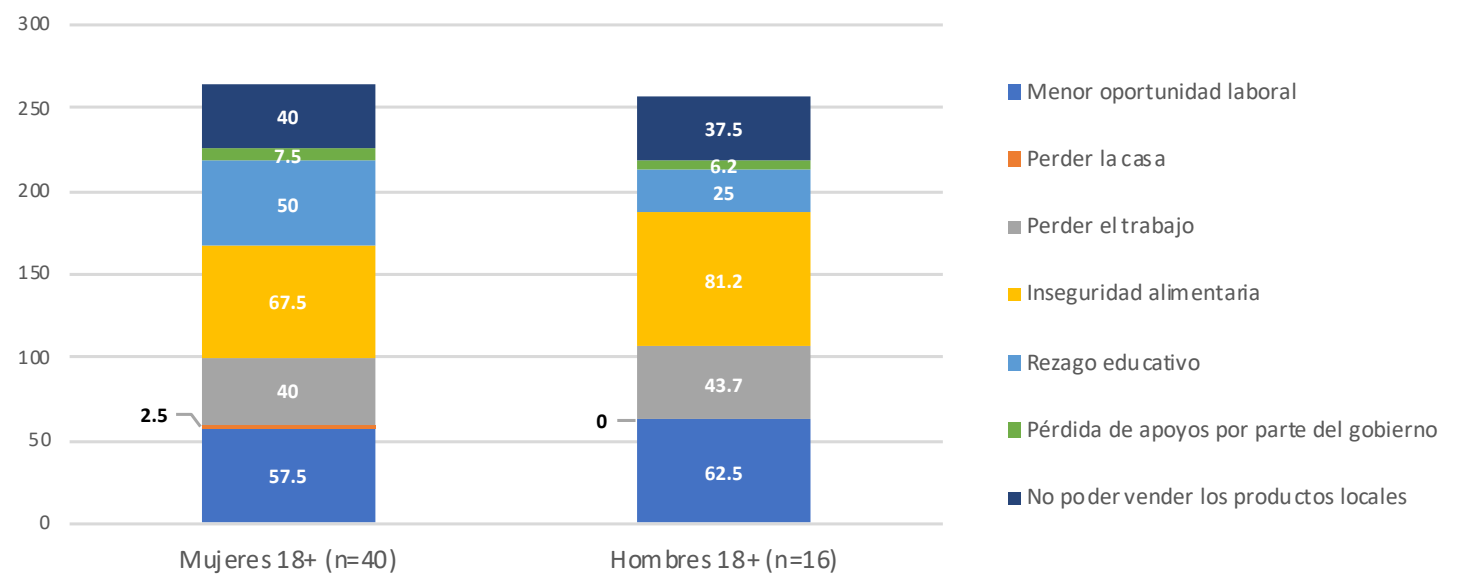

Nota: Los porcentajes no suman $100 \%$ por ser pregunta con respuesta de opción múltiple

mayor porcentaje en hombres $(81.2 \%)$ en comparación con las mujeres $(67.5 \%)$ y en segundo lugar la menor oportunidad laboral $(62.5 \%$ de los hombres y $57.5 \%$ de las mujeres). Para los hombres, la tercera preocupación más mencionada fue la pérdida del trabajo $(43.7 \%)$ y para las mujeres el rezago educativo $(50.0 \%)$. Se observa una mayor preocupación sobre el no poder vender productos locales entre mujeres $(40.0 \%)$ en comparación con los hombres (37.5\%). La pérdida de la casa solo fue mencionada por mujeres, pero en una proporción muy baja $(2.5 \%)$ (ver Figura 18).

Con relación a lo expresado por las autoridades comunitarias, se observa que la principal preocupación es no poder vender los productos locales (4/5 autoridades encuestadas). Dos de las cinco autoridades comunitarias mencionaron el aumento de la violencia familiar y contra las mujeres como una preocupación. Sin embargo, ninguna autoridad identificó como preocupación el aumento en otros tipos de violencia (delitos, crimen organizado, violencia comunitaria). La menor oportunidad laboral fue identificada como preocupación por una de las cinco autoridades encuestadas.

Sobre el grado de confianza que se tiene en las medidas implementadas por las autoridades municipales con respecto a la pandemia, la mayoría de las personas adultas contestaron (en una escala del 0 al 10, donde 0 es nada de confianza y 10 es mucha confianza) un puntaje de 5 . Por otro lado, a las autoridades comunitarias se les pidió calificar (con la misma escala) el grado de confianza en las medidas implementadas por las autoridades estatales y federales. Para ambos casos, la mayoría de las autoridades calificaron con 10 su grado de confianza.

Por último, se preguntó sobre los principales sentimientos que han tenido con respecto a la pandemia. En general, se identifica que tanto las mujeres adultas como las adolescentes identifican sentirse más tristes, con más desánimo y con más nervios en comparación con los hombres adultos y los adolescentes, quienes identifican como sentimientos principales la aburrición y tranquilidad. Sin embargo, $43.7 \%$ de los hombres adultos en Chiapas también perciben sentirse desanimados (ver Figura 19).

\section{Prácticas}

La Figura 20 muestra las prácticas que las personas adultas y adolescentes llevarían a cabo si presentaran síntomas de COVID-19. Se observa que la principal práctica que implementarían sería quedarse en casa y seguir las medidas de prevención recomendadas (91\% y $77.2 \%$, respectivamente). En el caso de personas adultas, la segunda sería usar cubrebocas $(37.5 \%)$ y en el caso de adolescentes acudir al centro de salud (59.0\%). 
Figura 19. Principales sentimientos expresados con respecto a la pandemia por grupo encuestado y sexo. Porcentajes. Chiapas, 2020.

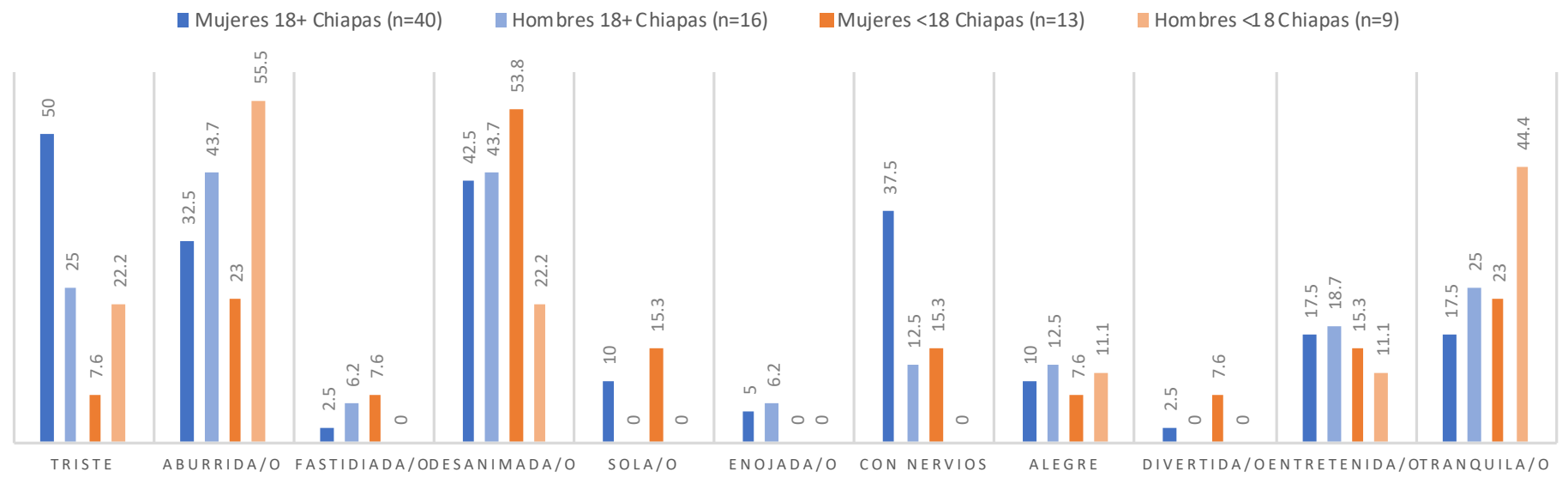

Nota: Los porcentajes no suman 100\% por ser pregunta con respuesta de opción múltiple

También se preguntó sobre las razones por las cuáles consideran que las personas de su comunidad no quieren o no pueden llevar a cabo las medidas de prevención recomendadas para prevenir la propagación del virus causante del COVID-19. Las tres principales razones mencionadas por las personas adultas fueron la imposibilidad de las personas de quedarse en casa porque tienen que salir a trabajar (71.4\%), el que las personas en su comunidad no consideran que el COVID-19 sea un problema importante de salud $(46.4 \%)$ y vivir en casas de una sola habitación (46.4\%). Las tres principales razones mencionadas por las y los adolescentes fueron el que las personas en su comunidad no consideran que el COVID-19 sea un problema importante de salud (68.1\%), la necesidad de salir a trabajar $(54.5 \%)$ y que no ha llegado mucha información sobre el COVID-19 a su comunidad (40.9\%). Adicionalmente, $57.0 \%$ de las personas adultas encuestas identificaron no contar con una habitación para aislarse ellas mismas o a algún familiar en caso de presentar síntomas de COVID-19.

Figura 20. Medidas de prevención de COVID-19 utilizadas más frecuentemente por grupo encuestado y sexo. Porcentajes. Chiapas, 2020.

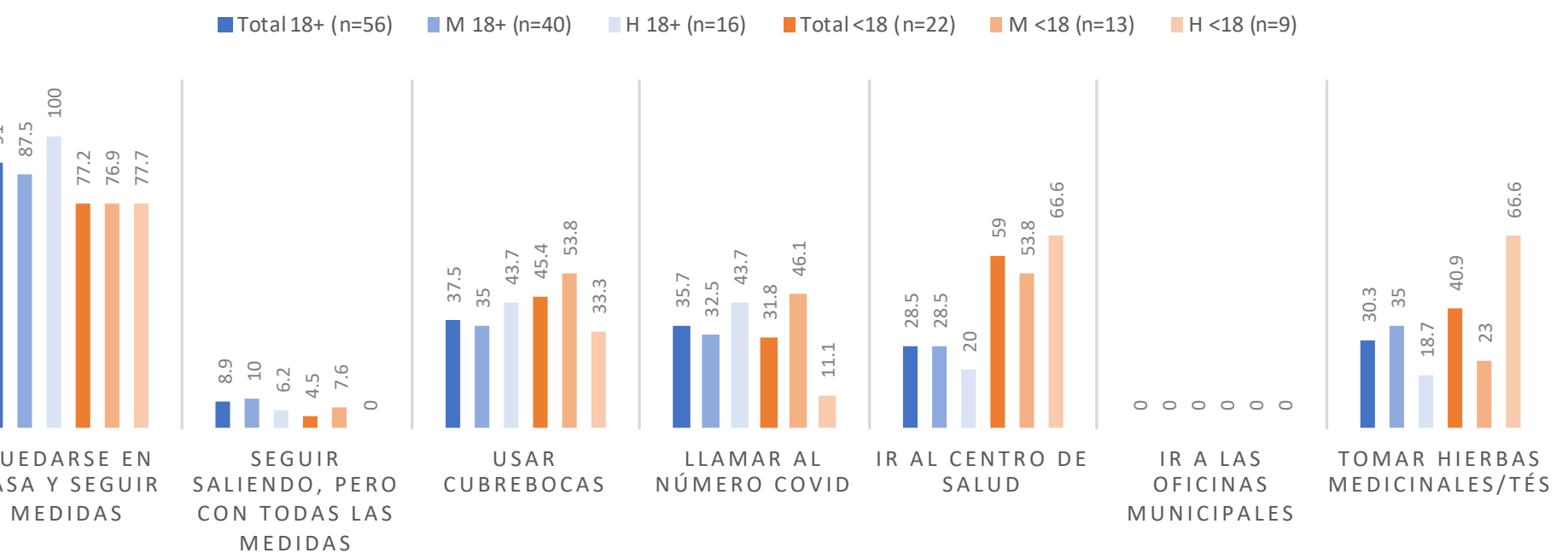

Nota: Los porcentajes no suman $100 \%$ por ser pregunta con respuesta de opción múltiple 
Sobre las medidas de prevención y control de la pandemia implementadas a nivel local que fueron identificadas por las autoridades comunitarias encuestadas del municipio de Las Margaritas, se identificaron las siguientes: toque de queda, retén a la entrada de la comunidad, dejar pasar solamente a las personas que llevan alimentos y exhortar a la población a seguir las medidas de prevención y control recomendadas.

Con respecto a acciones que las personas adultas han visto que se han implementado en su comunidad desde la pandemia, se analizaron las respuestas de las personas encuestadas de acuerdo con el municipio en el que viven:

\section{Municipio}

\section{Aldama}

Amatenango del Valle

Chenalhó

\section{Acciones implementadas}

Se mencionó quedarse en casa e ir al médico.

Se mencionó el evitar salir de casa salvo por algo necesario.

Las personas se han quedado en casa y se han reducido las visitas a amistades y familiares.

»Se ha solicitado a las personas de las comunidades ya no viajar a San Cristóbal de las Casas, ya que ahí es en dónde pueden correr más riesgo de contagiarse.

» En la comunidad de Belisario Domínguez, también mencionaron que se les solicitó evitar en lo posible la cabecera municipal.

»En Poconichim se cerró la comunidad y no se aceptan visitas de personas ajenas al municipio. En caso de que no se sigan estas indicaciones, las autoridades comunitarias multan a las personas.

\section{Chilón}

» En la comunidad de Gololton se menciona que la acción a tomar por parte de las autoridades fue no dejar entrar a las personas que vienen de otros estados.

»Quisisal, se menciona que las personas ya no se saludan de mano y no se realizan reuniones con varias personas.

\section{Huixtán}

Las autoridades y las personas de la comunidad decidieron tapar la entrada a la comunidad de San Pedro Pedernal y no dejar pasar a personas ajenas y personas que estén fuera de la comunidad.

Las Margaritas No se mencionó ninguna acción a nivel comunitario. Se identifican como medidas el uso de cubrebocas, el uso de gel antibacterial y mantener la sana distancia.

Ocosingo

En Ocosingo, mencionan que se evita saludar de manos y no se hacen reuniones en la comunidad.

Oxchuc

Se identifica que no hay muchas medidas de prevención implementadas, más allá del uso de cubrebocas.

San Andrés Larráinzar

En San Andrés Larráinzar, se ha repartido información por parte de las autoridades a las comunidades y se han instalado puntos de lavado de manos y gel antibacterial a la entrada y salida de la comunidad.

\section{San Cristóbal de las Casas} Se mencionan como medidas comunitarias el no realizar reuniones con muchas personas, el uso de cubrebocas, el lavado de manos y uso de gel antibacterial y mantener la sana distancia.

San Juan Cancuc

En San Juan Canuc, se identifica que la percepción en general es que no hay muchas acciones comunitarias con respecto a medidas de prevención en las comunidades. En la Cabecera Municipal se menciona que se están evitando reuniones de muchas personas y en Xpumul se menciona quedarse en caso y solo salir si hay algo urgente. 


\begin{tabular}{|c|c|}
\hline Sitalá & $\begin{array}{l}\text { En Sitalá, se mencionan actividades distintas dependiendo de la comunidad: } \\
\text { »En Insurgentes Picoté, la acción tomada fue no dejar entrar a la comunidad personas que vie- } \\
\text { nen de otros estados. } \\
\text { » En Santa Isabel, no se identifica ninguna acción para la prevención a nivel comunitario. } \\
\text { »En San Francisco La Unión, ya no se hacen reuniones de varias personas en la comunidad. } \\
\text { »En San Juan de la Montaña, describen que solo algunas personas no salen de la comunidad. } \\
\text { ¿n la Cabecera Municipal, se menciona el uso de cubrebocas y que las autoridades han pedido } \\
\text { a la gente que se quede en su casa. }\end{array}$ \\
\hline Tenejapa & $\begin{array}{l}\text { Al igual que en San Juan Canuc, no se identifican un gran número de actividades a nivel comunita- } \\
\text { rio. Se identifica que algunas personas ya no se dan la mano o se abrazan y que pocas personas } \\
\text { utilizan cubrebocas. }\end{array}$ \\
\hline
\end{tabular}

Por último, a las autoridades comunitarias se les preguntó en cuáles situaciones referirían a una persona a atención médica a personas con síntomas de salud. La Tabla 11 muestra los resultados de las cinco autoridades comunitarias encuestadas en Chiapas.

Tabla 11. Valoración por autoridades municipales sobre la necesidad de referencia a atención médica a una persona con síntomas de COVID-19 con base en distintos escenarios clínicos. Chiapas, 2020.

\begin{tabular}{|lc|}
\hline Escenario clínico & $\mathrm{n} / \mathrm{N}$ \\
\hline Una persona joven sin otra comorbilidad que presenta síntomas leves & $1 / 5$ \\
\hline Una persona joven sin otra comorbilidad que presenta síntomas graves & $3 / 5$ \\
\hline Persona perteneciente a un grupo de riesgo que presenta síntomas leves & $1 / 5$ \\
\hline Persona perteneciente a un grupo de riesgo que presenta síntomas graves & $1 / 5$ \\
\hline $\begin{array}{l}\text { Cualquier persona que haya estado en contacto con alguien que presentaba sínto- } \\
\text { mas de CoVID-19 }\end{array}$ & $4 / 5$ \\
\hline
\end{tabular}

\section{Medios de comunicación y diseminación de información relativa aCOVID-19}

\section{Confianza en medios de comunicación para informarse sobre COVID-19}

La primera dimensión preguntada con relación a los medios de comunicación fue indicar en cuál medio de comunicación confían más para informarse sobre el COVID-19. Esta pregunta se realizó a población adulta y población adolescente (ver Figura 21).

El principal medio de comunicación al cual le tienen confianza las mujeres adultas son los programas de radio (31.5\%). Los hombres adultos le tienen más confianza a las conferencias oficiales diarias del gobierno sobre COVID-19 (40.0\%). En el caso de población adolescentes, los hombres le tienen más confianza al centro de salud (33.3\%) y las mujeres al perifoneo, el centro de salud y los programas de radio (15.3\%). Para el caso de Chiapas, se observa una muy baja confianza de las personas adultas hacia las redes sociales para informarse sobre COVID-19 $(3.7 \%)$ y ninguna persona adolescente las mencionó como el medio de comunicación en el que se le tiene más confianza para informarse sobre el COVID-19.

Con respecto a las autoridades, los medios 
Figura 21. Porcentaje de personas adultas y adolescentes por medio de comunicación al cual le tienen más confianza para informarse sobre el COVID-19. Chiapas, 2020.

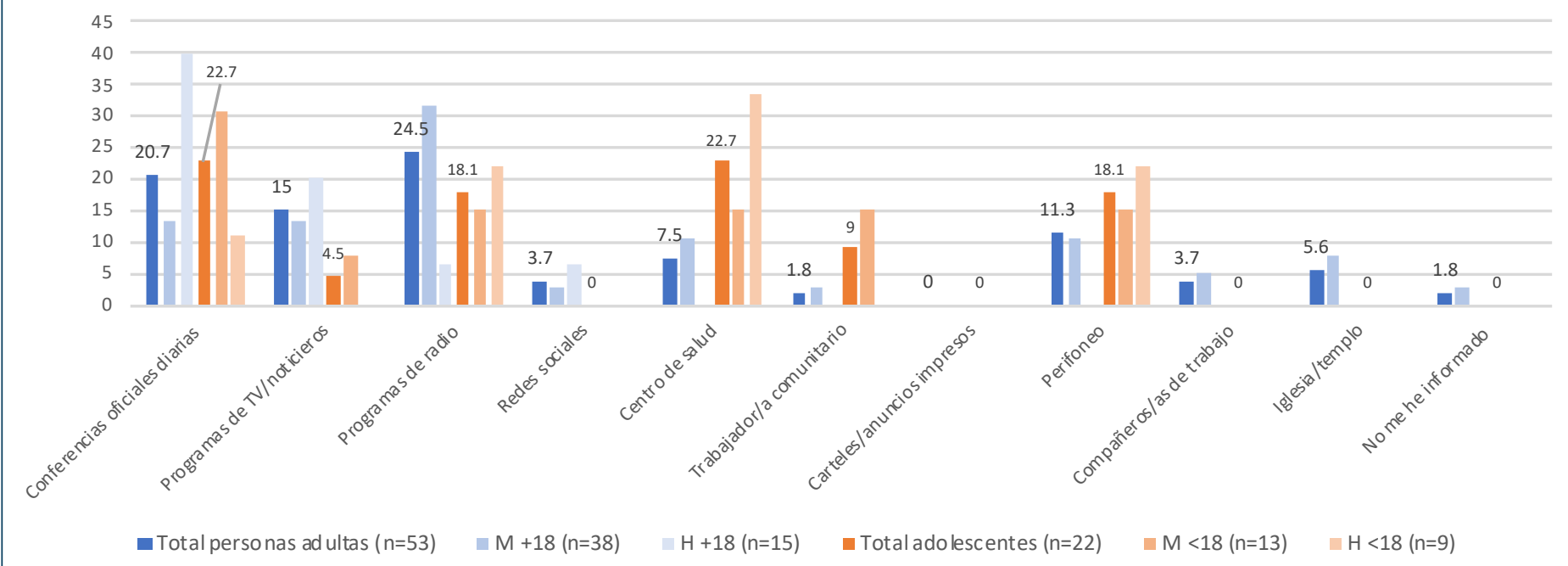

Nota: Los porcentajes no suman 100\% por ser pregunta con respuesta de opción múltiple

de comunicación que más utilizan para mantenerse informados sobre la pandemia son: conferencias oficiales diarias del gobierno (5/5 autoridades encuestadas), programas de radio (3/5), y el perifoneo (2/5). Ninguna autoridad mencionó utilizar las redes sociales como un medio de comunicación para informase sobre el COVID-19.

\section{Idioma de preferencia para recibir información sobre COVID-19}

La primera dimensión preguntada con relación a los medios de comunicación fue indicar en cuál medio de comunicación confían más para informarse sobre el COVID-19. Esta pregunta se realizó a población adulta y población adolescente (ver Figura 21).

La segunda dimensión preguntada sobre medios de información, fue la preferencia de idioma para recibir información sobre COVID-19 escrita y en radio, televisión y redes sociales. Esta pregunta también fue realizada a personas adultas y adolescentes.

Se identifica que $55.3 \%$ de la población adulta y $40.9 \%$ de la población adolescente preferiría recibir la información escrita sobre COVID-19 en Español, 48.2\% y 27.2\% en Tseltal, respectivamente y $26.7 \%$ y $40.9 \%$ en Tsotsil, respectivamente. Para la información recibida por radio, televisión y redes sociales, los porcentajes de preferencia de idioma son parecidos, con $55.3 \%$ de la población adulta y $36.3 \%$ de la población adolescente preferirían recibir esta información en Español, 44.6\% y 27.2\%, respectivamente, en Tseltal y $40.9 \%$ y $30.3 \%$, respectivamente, en Tsotsil.

\section{Medio de comunicación de preferencia} para diseminar la información sobre COVID-19, sobre todo para población hablante de una lengua indígena

Por último, se preguntó a la población adulta cuáles creían que eran los medios de comunicación más aptos para diseminar información sobre COVID-19 en población hablante de lengua indígena (ver Figura 22). Se observa que las personas adultas preferirían que la información sobre COVID-19 en sus comunidades se diseminara a través de promotores/as comunitarias (46.4\%), el centro de salud (44.6\%), programas de radio (35.7\%) y perifoneo (30.3\%). 
Figura 22. Porcentaje de personas adultas y autoridades por medio de comunicación de preferencia para informar a la población, sobre todo a población hablante de una lengua indígena, sobre el COVID-19. Chiapas, 2020.

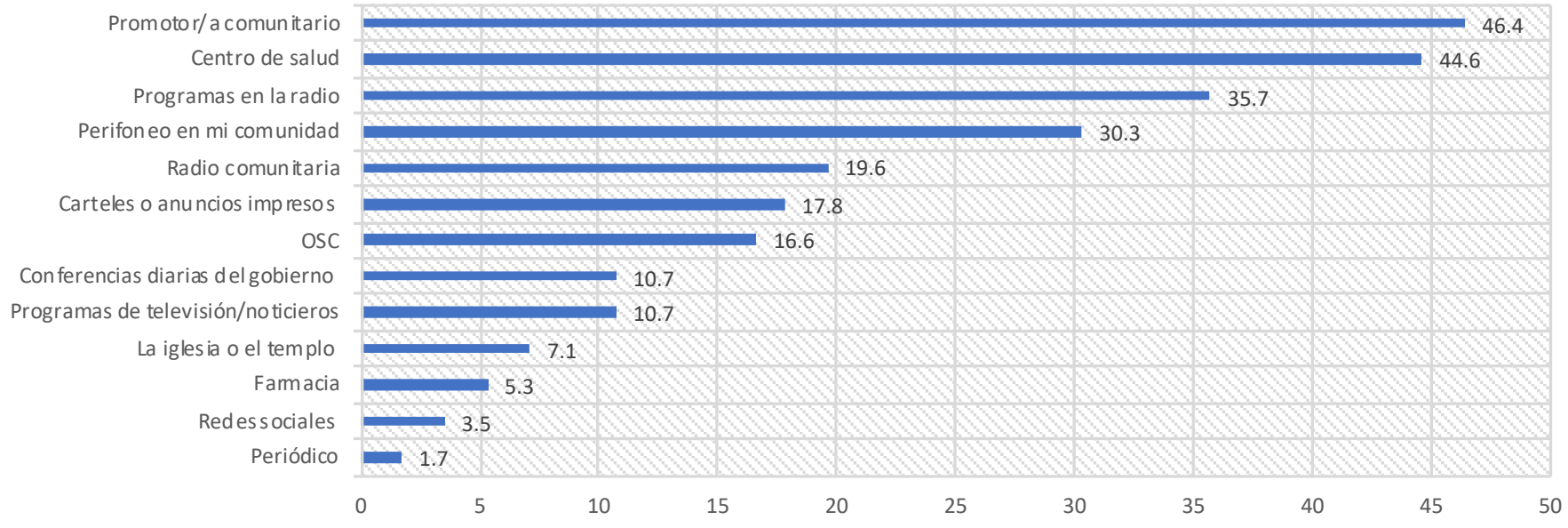

Nota: Los porcentajes no suman $100 \%$ por ser pregunta con respuesta de opción múltiple

\section{Impacto de la pandemia en distintas dimensiones de la vida de la población encuestada}

\section{Inseguridad alimentaria}

En Chiapas, $12.5 \%$ de las personas adultas y $18.2 \%$ de las y los adolescentes identificaron no haber desayunado, comido y/o cenado en la última semana debido a que no había suficiente comida para alimentar a toda la familia (ver Figura 23). Se observa que 17.5\% de las mujeres adultas en comparación con ninguno de los hombres adultos se encontraron en esta situación, mientras que $20.2 \%$ de las mujeres adolescentes en comparación con 8.0\% de los hombres adolescentes habían estado en esta situación en la semana previa a la encuesta.

\section{Impacto económico de la pandemia en población adulta encuestada}

Del total de personas adultas encuestadas en Chiapas, $37.5 \%$ de las mujeres y $25.0 \%$ de los hombres habían perdido su trabajo y/o principal fuente de ingreso desde el inicio de la pandemia. Así mismo, 35.0\% de las mujeres adultas y $46.6 \%$ de los hombres adultos identificaron contar con ahorros.
De las personas que contaban con ahorros, $8.33 \%$ de las mujeres y $66.6 \%$ de los hombres contestaron que estos ahorros les durarían más de un mes para sostener a su familia, $33.3 \%$ de las mujeres y $0.0 \%$ de los hombres contestaron que los ahorros durarían entre una semana y un mes y $58.3 \%$ de las mujeres y $33.3 \%$ de los hombres que dichos ahorros durarían menos de una semana. $16.3 \%$ de las personas adultas encuestadas cuentan con un apoyo por parte del gobierno.

Por otro lado, se preguntaron las actividades económicas realizadas en casa. La principal actividad económica identificada fue el hacer milpa $(60.7 \%)$ y en segundo lugar se mencionó el tener animales de patio que pueden consumir (42.8\%). 21.4\% de las personas adultas identificaron no realizar ninguna de las actividades económicas mencionadas. $59.5 \%$ mencionó que la milpa, la cosecha de frutas y verduras y los animales de patio no son suficientes para consumo propio.

Por último, se preguntó sobre algunas estrategias familaries implementadas para disminuir el impacto económico de la pandemia. Un mayor porcentaje de hombres mecionó la producción de alimentos (56.2\%) y el 
Figura 23. Porcentaje de personas adultas y adolescentes que no desayunaron, comieron y/o cenaron en la semana previa a la encuesta debido a que no había suficiente comida para toda la familia por sexo. Chiapas, 2020

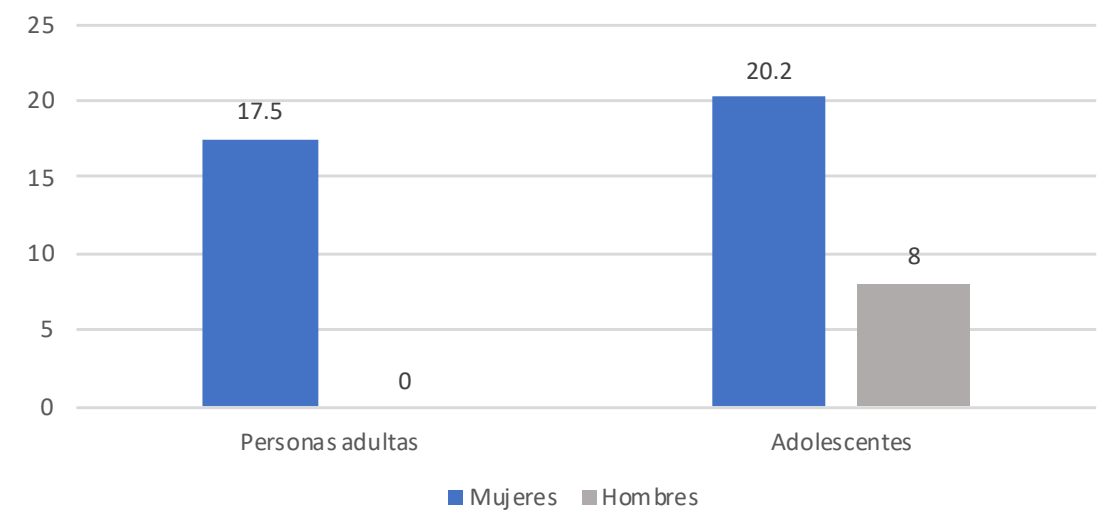

Nota: Los porcentajes no suman 100\% por ser pregunta con respuesta de opción múltiple

cuidar de los ahorros como estrategias para disminuir el impacto económico en comparación con las mujeres $(52.5 \%$ y $30.0 \%$, respectivamente). $10.0 \%$ de las mujeres indicó no estar implementando una estrategia en comparación con cero hombres (ver Figura 24).

Figura 24. Porcentaje de personas adultas que han implementado una estrategia familiar para disminuir el impacto económico, por estrategia implementada. Chiapas, 2020.

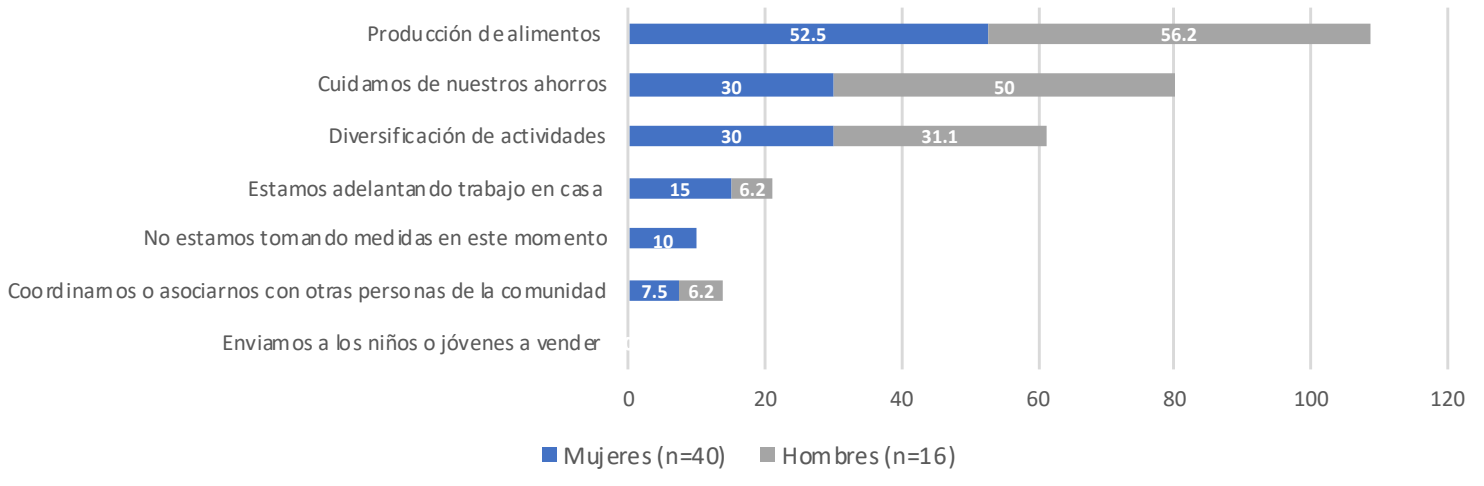

Nota: Los porcentajes no suman $100 \%$ por ser pregunta con respuesta de opción múltiple

\section{Otras dimensiones exploradas}

Finalmente, se exploró quiénes son las personas que han realizado los trabajos del hogar y si han sufrido violencia en casa durante el periodo de confinamiento por la pandemia de COVID-19.

- $69.0 \%$ de las personas adultas identificaron que son las mujeres quiénes realizan los trabajos del hogar, y el $31.0 \%$ restante mencionó que todas y todos ayudan en casa para realizar los trabajos del hogar.

- Del total de personas adultas encuestadas, tanto adultas como adolescentes, ninguna refirió haber vivido golpes, gritos, empujones o malos tratos en casa durante el periodo de confinamiento.

\section{Educación y COVID-19 en población adolescente encuestada}

Del total de adolescentes encuestados, 75.0\% de las adolescentes y $62.5 \%$ de los adolescentes indicaron que siguieron estudiando en casa durante la pandemia. La estrategia utilizada en mayor porcentaje para continuar 
Figura 25. Porcentaje de personas adolescentes que refieren haber tenido una experiencia positiva durante la pandemia, por tipo de experiencia y sexo. Chiapas, 2020.

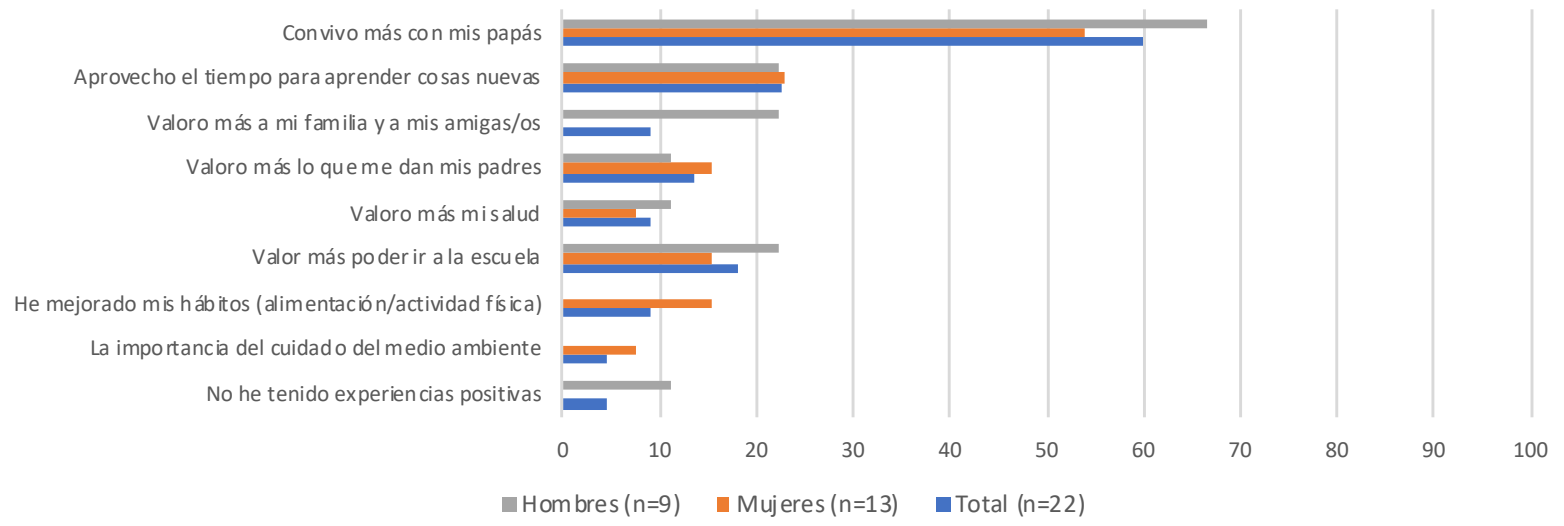

Nota: Los porcentajes no suman $100 \%$ por ser pregunta con respuesta de opción múltiple

con sus estudios fue seguir las indicaciones que mandan las y los docentes por Whatsapp y/o redes sociales. La estrategia menos utilizada $(<5.0 \%)$ fue seguir adelante por su cuenta utilizando los libros de texto.

Sobre cómo se sentían con respecto a la modalidad de estudio en casa, se observa que $22.7 \%$ de las y los adolescentes identifican que dejan mucha tarea, $18.1 \%$ mencionó que les gusta ya que pueden ir a su ritmo, $5.0 \%$ se siente preocupada/o y $4.5 \%$ mencionó sentirse desinteresado/a en la escuela.

Por otro lado, cuatro de las nueve mujeres adolescentes que siguen estudiando en casa identificaron contar con apoyo en casa para resolver dudas relacionadas con la escuela, en comparación con uno de los cinco hombres adolescentes que siguen estudiando en casa.

Por último, 30.7\% de las mujeres adolescentes identificaron contar con acceso a internet en casa, en comparación con $22.2 \%$ de los hombres adolescentes. Es decir, aproximadamente $75.0 \%$ del total de población adolescente encuestada no cuenta con acceso a internet en casa.

\section{Experiencias y aprendizajes positivos durante la pandemia en la población adolescente encuestada}

Finalmente, se exploró quiénes son las personas que han realizado los trabajos del hogar y si han sufrido violencia en casa durante el periodo de confinamiento por la pandemia de COVID-19.

La Figura 26 muestra el porcentaje de adolescentes mujeres y hombres que han aprendido nuevas actividades desde el inicio de la pandemia por COVID-19. Se observa que un mayor porcentaje de mujeres ha aprendido a hacer artesanías (46.1\%), a cocinar (30.7\%) y a hacer labores del hogar $(23.0 \%)$ con respecto a los hombres. Por otro lado, un mayor porcentaje de hombres han aprendido más del trabajo de la milpa (55.5\%) en comparación con las mujeres. Asimismo, un mayor porcentaje de hombres identifica no haber aprendido nada en comparación con las mujeres ( $44.4 \%$ vs. $7.6 \%$, respectivamente). En estas tendencias podemos observar cómo los roles de género permean las actividades que aprenden las mujeres y hombres adolescentes en casa.

\section{Redes de apoyo durante la pan- demia de la población adolescente encuestada}

La última dimensión que fue estudiada en el presente estudio fueron las redes de apoyo con las que cuentan las y los adolescentes durante la pandemia. Se preguntó sobre frecuencia en la que comparten sus sentimientos con respecto a la pandemia, con quién los comparten y grado en el que se sienten escuchadas y escuchados. 
Figura 26. Porcentaje de adolescentes que han aprendido a realizar nuevas actividades durante la pandemia, por tipo de actividad aprendida y sexo. Chiapas, 2020.

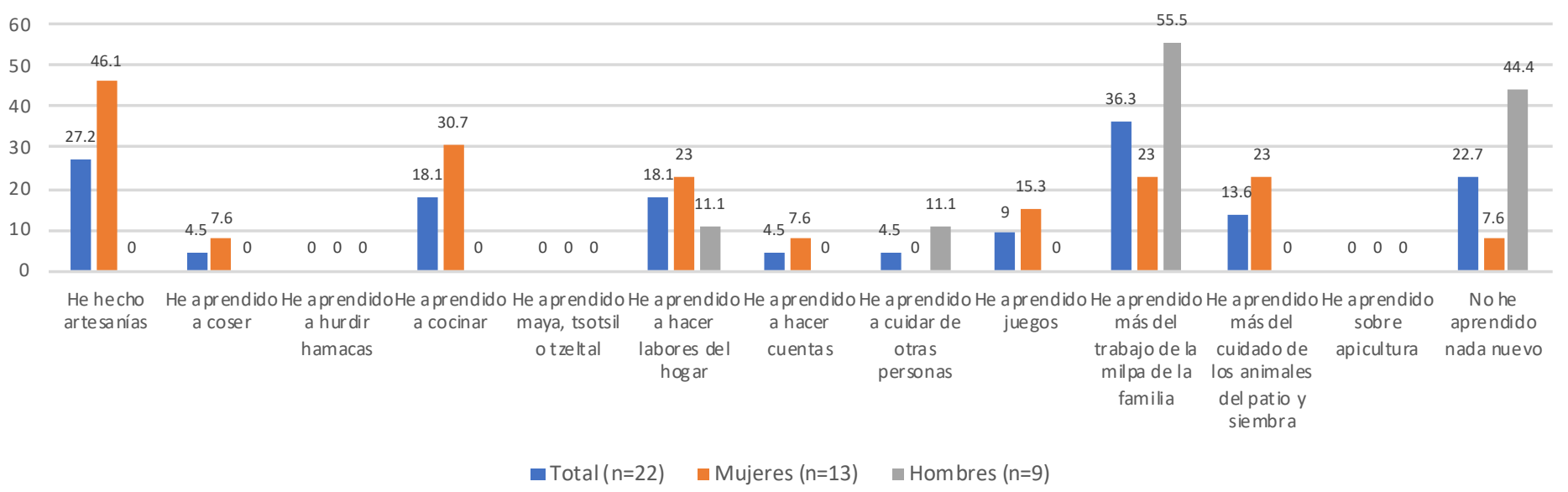

Nota: Los porcentajes no suman 100\% por ser pregunta con respuesta de opción múltiple

Sobre la frecuencia con la que comparten sus sentimientos, se observa que un mayor porcentaje de hombres adolescentes comparte sus sentimientos casi siempre (11.1\%) en comparación con las mujeres adolescentes $(7.6 \%)$ y que, por el contrario, un mayor porcentaje de mujeres adolescentes nunca o casi nunca los comparte con alguien (69.1\%) como se siente en comparación con los hombres $(44.4 \%)$.

La Tabla 12 muestra las personas con las que más frecuentemente comparten cómo se sienten. En general, las mujeres adolescentes comparten sus sentimientos principalmente con su mamá $(61.5 \%)$ y los hombres adolescentes comparten sus sentimientos principalmente tanto con su mamá como con su papá $(44.4 \%)$.

Finalmente, se preguntó sobre el grado en el que se sienten escuchadas y escuchados cuando comparten sus sentimientos. Se identificó que un mayor porcentaje de mujeres adolescentes $(53.7 \%)$ nunca o casi nunca se sienten escuchadas, en comparación con $25.0 \%$ de los hombres adolescentes. Un mayor porcentaje de hombres se sienten casi siempre escuchados $(25.0 \%)$ en comparación con las mujeres adolescentes (15.3\%).

Tabla 12. Personas con las que más frecuentemente las y los adolescentes comparten cómo se sienten con respecto a la pandemia. Chiapas, 2020.

\begin{tabular}{|ccc|}
\hline & $\begin{array}{c}\text { Mujeres }(\mathbf{n = 1 3 )} \\
\mathbf{n}(\%)\end{array}$ & $\begin{array}{c}\text { Hombres }(\mathbf{n}=9) \\
\mathbf{n}(\%)\end{array}$ \\
\hline Mamá & $8(61.5)$ & $4(44.4)$ \\
\hline Papá & $1(7.6)$ & $4(44.4)$ \\
\hline Hermana o prima & $2(15.3)$ & $1(11.1)$ \\
\hline Hermano o primo & 0 & 0 \\
\hline Tía & 0 & 0 \\
\hline Tío & 0 & $1(11.1)$ \\
\hline Abuela & 0 & $1(11.1)$ \\
\hline Abuelo & 0 & $1(11.1)$ \\
\hline Amiga/o & 0 & $1(11.1)$ \\
\hline Con nadie & $2(15.3)$ & \\
\hline
\end{tabular}




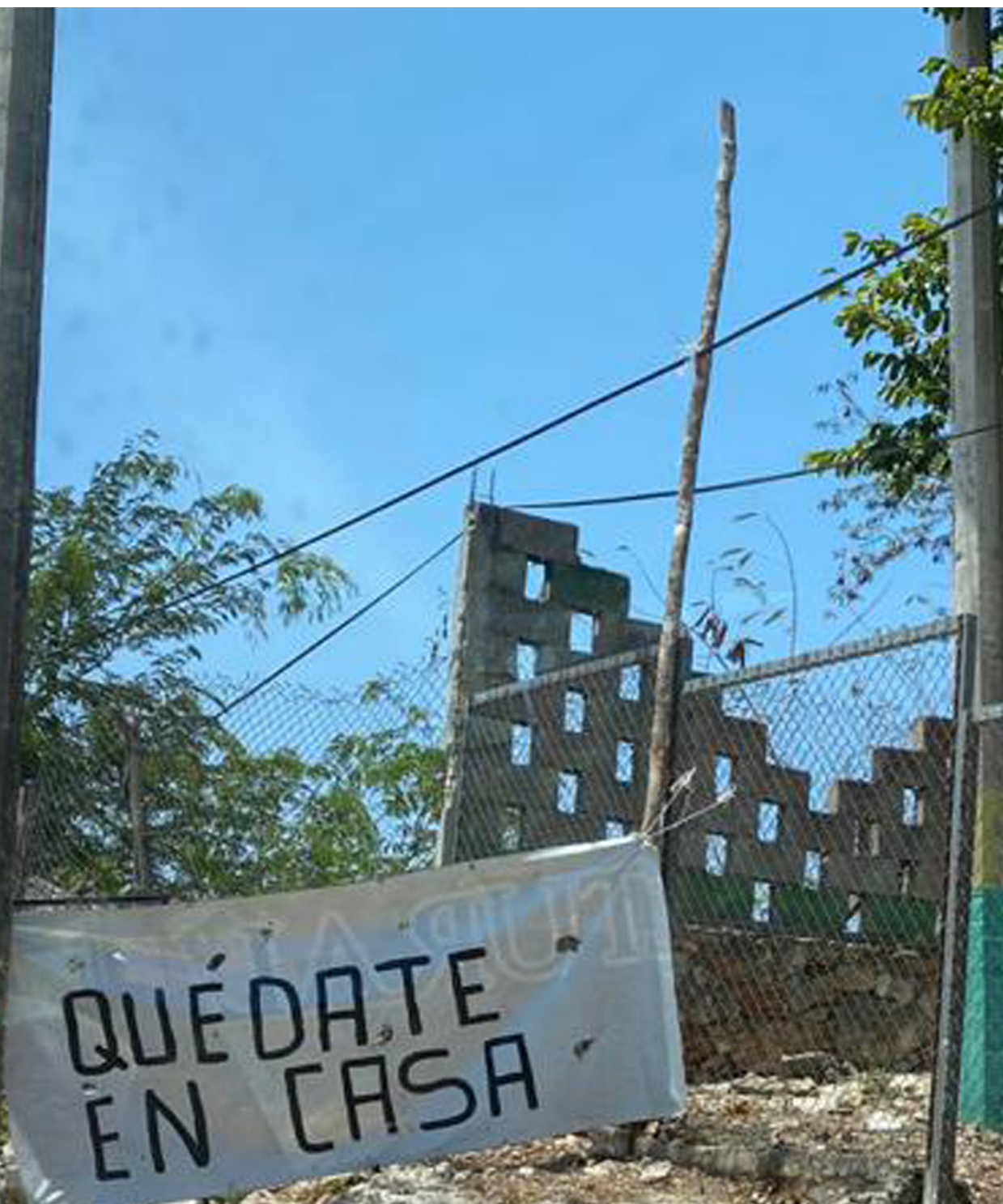

(1)

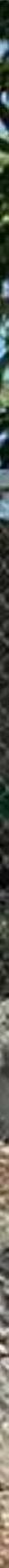

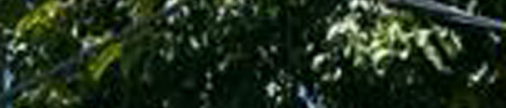


La Organización Mundial de la Salud ha recientemente indicado su preocupación sobre el mayor impacto que está teniendo y tendrá la pandemia por COVID-19 en la población ingdígena de la Región de las Américas. Aún cuando los resultados del presente estudio no sean representativos de toda la población indígena que vive en los municipios de Chiapas y Yucatán donde se realizó la encuesta, consideramos que los datos pueden, por un lado, identificar dimensiones que necesitan estudiarse a mayor detalle $y$, por otro, guiar algunas de las acciones de las organizaciones locales que trabajan en estas comunidades, señalando áreas de oportunidad con respecto a conocimientos, actitudes y prácticas, pero también hacia estrategias que disminuyan el impacto a mediano y largo plazo de la pandemia en estas comunidades. Recordando los retos y oportunidades que se presentan para enfrentar la pandemia en poblaciones indígenas, presentamos una lista de recomendaciones generales, necesidades identificadas y recomendaciones específicas para las autoridades competentes con base en los resultados obtenidos:

\section{Recomendaciones generales}

1. Reforzar las estrategias de comunicación sobre la pandemia por COVID-19. Se sugiere, por ejemplo:

- Diseñar estrategias de comunicación a través de los canales más confiables y en la lengua de preferencia en los diferentes grupos.

- Integrar una estrategia de comunicación intercultural para todas las comunicaciones que se realizan sobre la pandemia por COVID-19.

- Informar y difundir constantemente las fuentes de información confiables. Se sugiere hacer una compilación de fuentes confiables de información y diseñar mecanismos de difusión que atiendan las necesidades particulares de la población.

2. Reforzar conocimientos sobre los grupos con mayor riesgo de complicaciones por COVID19 -personas con comorbilidades y mayores de 65 ańos- y ampliar la información sobre otros grupos como mujeres embarazadas, menores de cinco ańos y personas con VIH, así como respecto a las medidas de prevención como la sanitización, el estornudo de etiqueta, el uso de cubrebocas y evitar el contacto con personas enferma de COVID-19 o evitar salir si se está enfermo.

3. Debido al porcentaje importante de personas adultas, adolescentes y autoridades comunitarias que consideran como ciertas prácticas para prevenir y/o eliminar el virus que no están basadas en evidencia empírica y que pueden afectar la salud de la población o exponerlas a un mayor riesgo por el retraso en la atención médica apropiada, se sugiere reforzar la comunicación sobre mitos y creencias entre la población de ambos estados.

4. Elaborar protocolos sensibles a la situación local sobre las medidas básicas para aislar a personas enfermas en caso de no contar con espacio físico independiente. Por ejemplo, se puede sugerir el uso de barreras físicas que reduzcan el contacto directo con la persona enferma (cortinas, cartulinas, etc), la limpieza constante de superficies si se comparte el baño y/o que un solo familiar se haga cargo de la persona que presenta síntomas, para disminuir el número de contactos de riesgo en la casa.

5. Asociado a que la mayor parte de las personas encuestadas no pueden quedarse en casa porque requieren salir a trabajar, es necesario reforzar las medidas de prevención recomendadas para prevenir contagios. Sobre todo: uso de cubrebocas y protección facial si salimos de casa (caretas), lavado constante de manos (con agua y jabón o con gen antibacterial), estornudar o toser en la parte interna del codo para evitar la propagación de las partículas virales y mantener una distancia de por lo menos 2 metros cuando estemos en contacto con otras personas.

6. Diseñar campañas de información enfocadas a prevenir el estigma en las comunidades hacia personas con COVID-19. La desinformación y el miedo a lo desconocido, pueden llevar a un aumento de las conductas discrimintarias que, a su vez, lleve a las personas con posible COVID-19 a no revelar que presentan algunos síntomas y, por lo tanto, a atención tardía y mayor probabilidad de contagios.

7. Difundir más ampliamente las herramientas de apoyo para la identificación y canaliza- 
ción de casos que necesitan atención médica, sobre todo entre autoridades comunitarias. Ya que, sí se cuentan con protocolos muy bien establecidos de cuándo es necesario referir a las personas a atención médica y quién es la autoridad responsable de hacerlo, se disminuye el retraso en la recepción de atención médica y, por otro lado, se evita la saturación de los hospitales y clínicas que han sido seleccionados para atender los casos de COVID-19.

\section{Necesidades identificadas}

1. Más de la mitad de la población encuestada muestra una preocupación importante con respecto a los impactos económicos y sociales que la pandemia tendrá en la comunidad, sobre todo relacionado a la inseguridad alimentaria, la pérdida laboral y la educación de sus hijas e hijos. Por otro lado, un porcentaje importante de las personas encuestadas identificaron haber perdido su trabajo o principal fuente de ingreso desde el inicio de la pandemia y solamente tres de cada diez personas encuestadas indicaron contar con ahorros para sostener a su familia. Estos resultados, si bien no son representativos de toda la población, si dan cuenta de las necesidades y los retos que plantea esta situación a tan sólo semanas de haber iniciado la jornada de Sana Distancia. Por lo que es urgente el desarrollo de planes integrales para mitigar el impacto económico, social y de salud en estas comunidades.

2. Por lo anterior, se identifica la necesidad de promover mesas de diálogo entre las organizaciones de la sociedad civil, gobierno y comunidad para diseñar de forma conjunta planes de desarrollo económico y social solidarios que amplíen las oportunidades y promuevan la colaboración en la comunidad para mitigar las consecuencias más apremiantes: la inseguridad alimentaria y las oportunidades laborales.

3. Por otro lado, se observa la necesidad de sistematizar y capitalizar los esfuerzos que se están dando a nivel comunitario para reducir el impacto económico en las comunidades (trueque, cooperativas, autoconsumo), ya que son estrategias que, impulsadas de la manera adecuada, pueden ser de vital importancia para enfrentar el impacto social y económico de la pandemia.
4. También, observamos la necesidad de evaluar a mayor profundidad el impacto que está generando la pandemia en la carga en el trabajo remunerado y no remunerado (cuidados en el hogar) en las mujeres.

5. La pandemia está ampliando brechas preexistentes en el acceso a la educación, el empleo, la seguridad alimentaria y las tecnologías de la información. El acceso a internet puede ser un mecanismo para acercar oportunidades e información a las comunidades. Por lo que, es necesario hacer incidencia y evaluar estrategias para ampliar el acceso a internet en las comunidades como un derecho social.

6. Evaluar el impacto del cierre de escuelas en tema de seguridad alimentaria e incluir en los planes de respuesta mecanismos que faciliten la distribución de apoyos alimentarios a los estudiantes.

7. Necesario fortalecer la cultura del ahorro y utilizar mecanismos comunitarios confiables. Se sugiere también difundir información sobre mecanismos confiables para el ahorro y como prevenir fraudes y endeudamientos. Es decir, fortalecer la educación financiera de la población, tomando en cuenta sus constumbres, capacidades, habilidades y preferencias.

8. La atención a la salud mental es una necesidad creciente en las comunidades. Se debe fortalecer la integración de personal competente en consejería y apoyo psicológico a los grupos de atención primaria a la salud y promover campañas de concientización sobre esta problemática. También es necesario ampliar el conocimiento de la población respecto a esfuerzos de apoyo psicológico a través de líneas telefónicas y digitales.

9. La pandemia también ha planteado serios retos para la atención primaria a la salud, incluyendo la atención de enfermedades crónicas y salud sexual y reproductiva. Se sugiere pensar en estrategias alternativas para la atención en salud. Un ejemplo de proyecto alternativo es la telemedicina, estrategia que ha sido implementada con éxito en otros países (15).

10. Se ha destacado el impacto de la pandemia de COVID-19 en el incremento del embarazo adolescente, debido a una disminución en el acceso a métodos anticonceptivos 
para esta población. Por lo que, se sugiere identificar con qué mecanismos se cuenta en los estados para garantizar el acceso continuo a estos métodos y qué áreas de oportunidad se encuentran para mejorarlos.

11. Incorporar a los planes de preparación y respuesta ante desastres naturales las acciones de prevención y mitigación de riesgos frente a agentes infecciosos, particularmente COVID19.

12. Mejorar el conocimiento sobre los efectos negativos de las normas de género y masculinidades nocivas en distintas dimensiones de la vida de las niñas y las mujeres y cómo es que impactan en las capacidades y recursos que las mujeres y niñas tienen a su disposición para enfrentar situaciones de crisis, como la pandemia por COVID-19.

13. Aún cuando un porcentaje muy bajo de las participantes refirió haber sufrido un evento de violencia desde que inició la pandemia, es importante resaltar que esto no significa que no suceda. En la discusión participativa de resultados, se comentó que la violencia es reconocida por un porcentaje muy bajo de las mujeres y niñas, sobre todo la violencia económica y psicológica. Por lo que, sugerimos difundir información sobre los distintos tipos de violencias, así como los mecanismos de prevención y atención para las mujeres y niñas que se encuentren en esta situación.

\section{Recomendaciones a las autoridades competentes}

1. Reforzar la capacitación sobre las medidas de atención y referencia de casos sospechosos, confirmados y graves de COVID-19.

2. Reforzar la capacitación sobre las creencias en prácticas que pueden afectar la salud de la población o exponerlas a un mayor riesgo por el retraso en la atención médica apropiada.

3. Reforzar la capacitación en estrategias de comunicación de riesgos a la población.

4. Fortalecer las medidas de prevención del estigma en las comunidades, especialmente en Yucatán.

5. Utilizar las fuentes y medios de comunicación que prefieren las personas que viven en la comunidad para difundir información a los distintos segmentos de población. Siempre tener en mente que las estrategias de comunicación deben modificarse de acuerdo a la población objetivo. Es decir, las fuentes y medios de comunicación utilizadas por mujeres y hombres y/o por personas adultas y adolescentes no son las mismas.

6. Promover estrategias de desarrollo económico solidario con la participación de diversos sectores, incluyendo las organizaciones de la sociedad civil que ya trabajan en estas comunidades.

7. Identificar a la población que está en condiciones de mayor vulnerabilidad y focalizar acciones y canalización de apoyos a estas poblaciones. Trabajar en conjunto con las organizaciones de la sociedad civil para estas iniciativas.

8. Promover acciones para fomentar normas de género y masculinidades positivas en las comunidades.

9. Fortalecer el conocimiento sobre los tipos de violencia y los servicios de prevención y atención de la violencia intrafamiliar y de género que existen en las distintas comunidades.

10. Fortalecer los servicios de procuración de justicia, los cuales también se han visto afectados por la pandemia de COVID-19.

11. Analizar la efectividad de las acciones de control de entrada a las comunidades, tanto en el número de casos como en las posibles consecuencias económicas y sociales de estas medidas. 


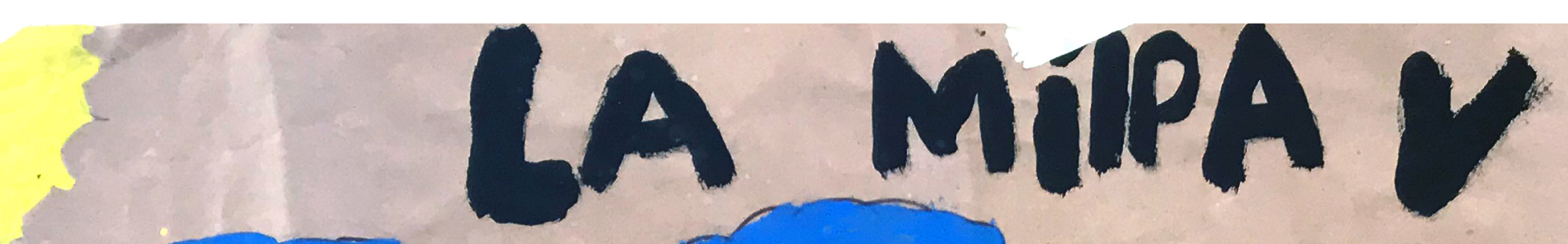

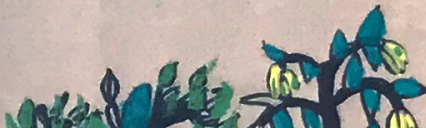

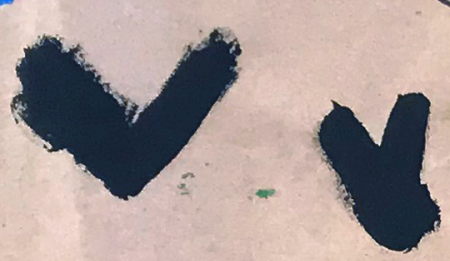

a.6. 告 $\int_{3}^{3}$
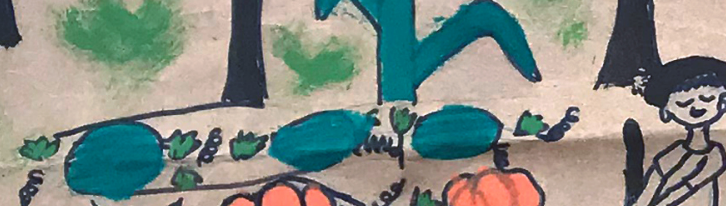

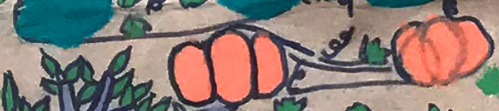

of $10+0^{\circ} 0^{\circ}=$

此
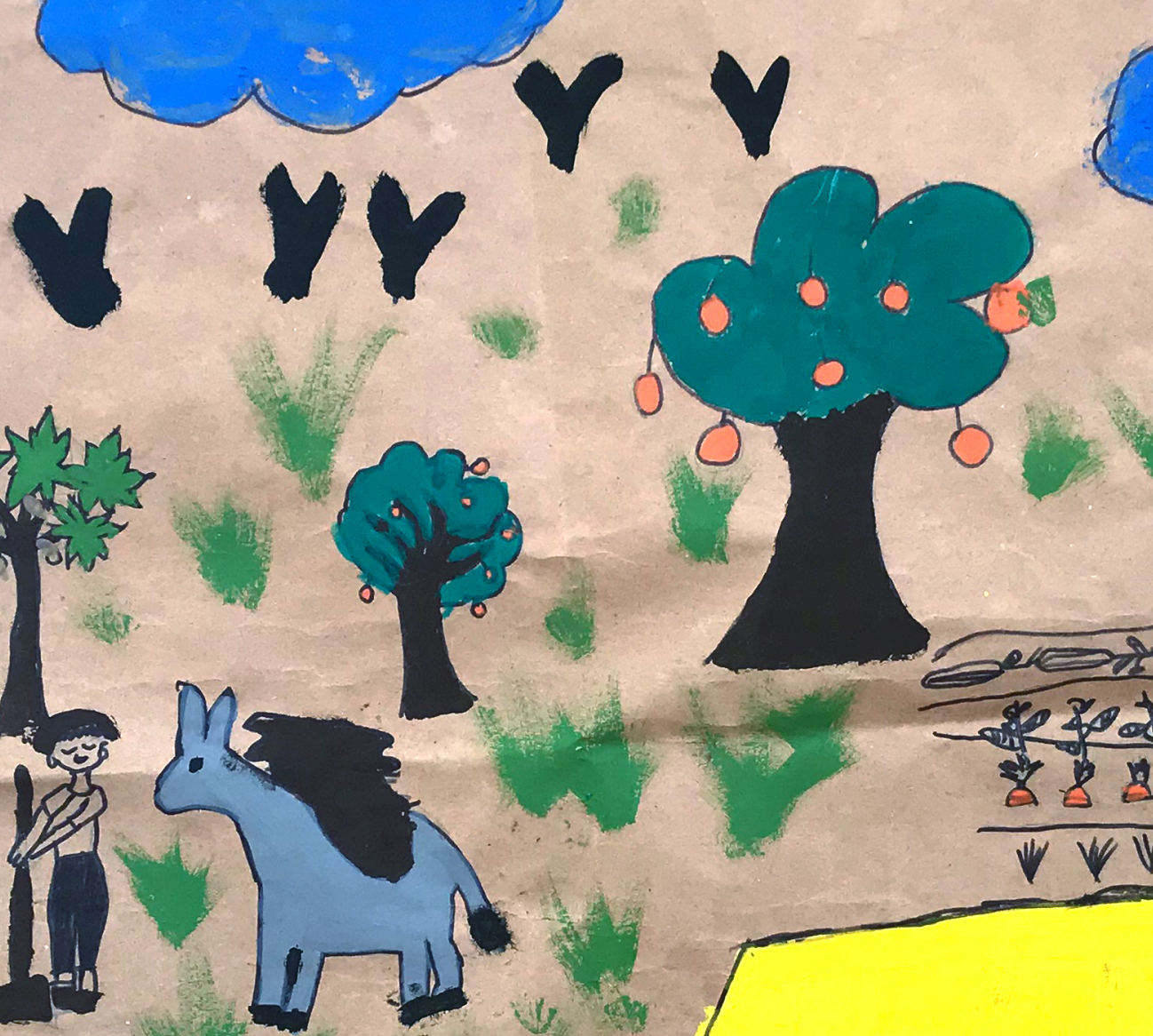

f

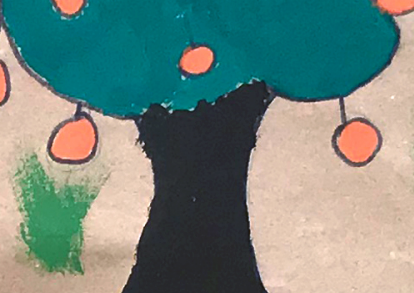

b
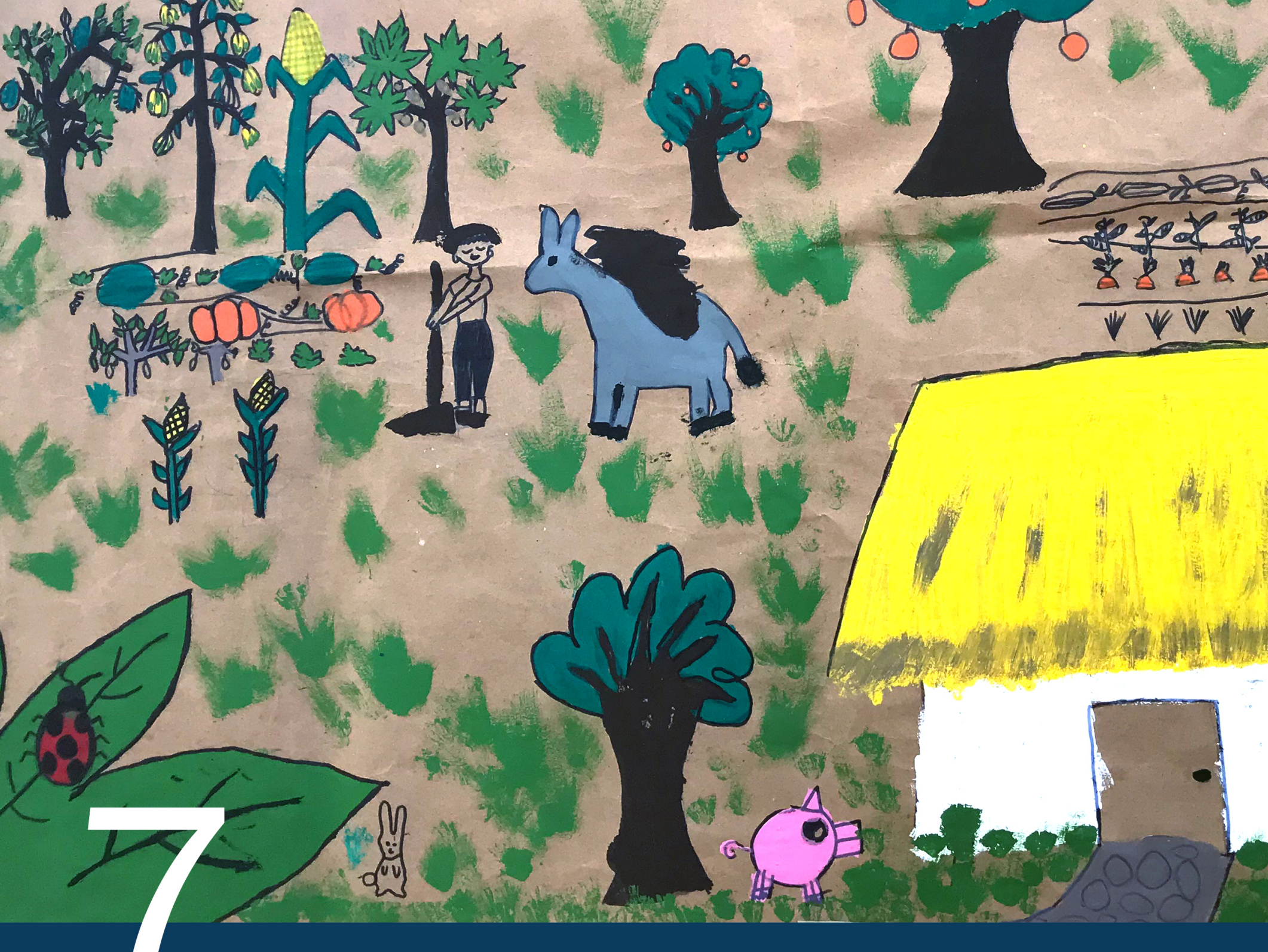

11

i) 6

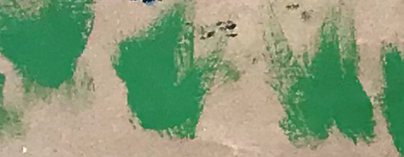

andestiander

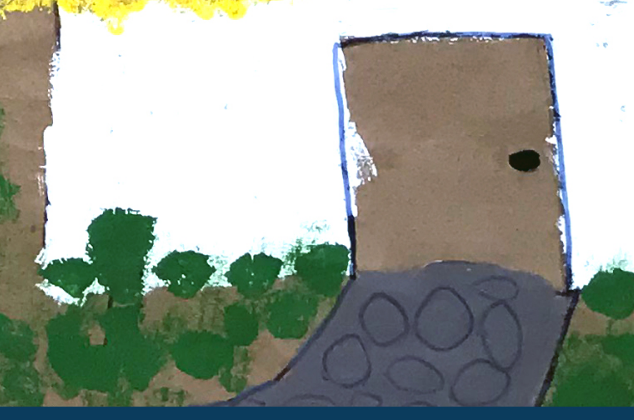

Referencias 
1. Instituto Nacional de Estadística y Geografía. Encuesta Intercensal 2015. Disponible en: https:/www.inegi.org.mx/programas/intercensal/2015/

2. Secretaría de Desarrollo Social (SEDESOL). Sistema de Apoyo para la Planeación del PDZP. Resumen estatal Yucatán. 2010. Disponible en:

http://www.microrregiones.gob.mx/catloc/Default.aspx?tipo=clave\&campo=mun\&valor=31

3. Consejo Nacional de Evaluación de la Política de Desarrollo Social (CONEVAL). Medición de la pobreza, Estados Unidos Mexicanos, 2010-2015. Indicadores de pobreza por municipio. México. Disponible en: https://www.coneval.org.mx/Medicion/Paginas/AE_pobreza_municipal.aspx

4. Secretaría de Desarrollo Social (SEDESOL). Sistema de Apoyo para la Planeación del PDZP. Resumen estatal Chiapas. 2010. Disponible en:

http://www.microrregiones.gob.mx/catloc/Default.aspx?tipo=clave\&campo=mun\&valor=07

5. Gobierno de México. Programa Regional de Desarrollo. Región V Altos Tsotsil-Tseltal. s/f. Disponible en: http://www.haciendachiapas.gob.mx/planeacion/informacion/desarrollo-regional/ prog-regionales/altos.pdf

6. Instituto Nacional de Estadística y Geografía. Panorama sociodemográfico de Chiapas. 2015. Disponible en: http://internet.contenidos.inegi.org.mx/contenidos/Productos/prod_serv/contenidos/espanol/bvinegi/productos/nueva_estruc/inter_censal/panorama/702825082154.pdf

7. Dirección General de Epidemiología. COVID-19 México: Casos acumulados por Entidad Federativa de Residencia. Secretaría de Salud. Disponible en: https://covid19.sinave.gob.mx

8. Dirección General de Epidemiología. COVID-19 México: Defunciones positivas y sospechosas por fecha de ocurrencia. Secretaría de Salud. Disponible en: https://covid19.sinave.gob.mx/Defunciones.aspx

9. Secretaría de Salud de Yucatán. Panorama Municipal COVID-19. Situación de casos por municipios. 15 de julio de 2020. Disponible en: http://www.yucatan.gob.mx/saladeprensa/ver_nota. php?id=3152

10. Secretaría de Salud. Gobierno de Chiapas. Casos de Coronavirus por estado en México. 15 de julio de 2020. Disponible en: http://coronavirus.saludchiapas.gob.mx/casos-covid-19

11. Secretaría de Salud. COVID-19 México: Panorama en población que se reconoce como indígena. Sábado 18 de julio de 2020. México. Disponible en:

https:/www.gob.mx/cms/uploads/attachment/file/564615/panorama-covid19-poblacion-indigena-18-julio-2020.pdf

12. Meneses-Navarro et.al. The challenges facing indigenous communities in Latin America as they confront the COVID-19 pandemic. International Journal for Equity in Health 2020;19:63. https://doi.org/10.1186/s12939-020-01178-4

13. Ioannidis, JPA. (2020). Coronavirus disease 2019: The harms of exaggerated information and non-evidence-based measures. European Journal of Clinical Investigation, n/a(n/a), e13223. https://doi.org/10.1111/eci.13223.

14. Jalloh, M. F. (2017). Knowledge, Attitudes, and Practices Related to Ebola Virus Disease at the End of a National Epidemic_-Guinea, August 2015. MMWR. Morbidity and Mortality Weekly Report, 66. https://doi.org/10.15585/mmwr.mm6641a4.

15. Blix M and Jeansson J. Telemedicine and the Welfare State: The Swedish Experience. Research Institute of Industrial Economics. Sweden, 2018. 